University of Chicago Law School

Chicago Unbound

Journal Articles

Faculty Scholarship

1999

\title{
The Questionable Empirical Basis of Article 2's Incorporation \\ Strategy: A Preliminary Study
}

Lisa Bernstein

Follow this and additional works at: https://chicagounbound.uchicago.edu/journal_articles

Part of the Law Commons

\section{Recommended Citation}

Lisa Bernstein, "The Questionable Empirical Basis of Article 2's Incorporation Strategy: A Preliminary Study," 66 University of Chicago Law Review 710 (1999).

This Article is brought to you for free and open access by the Faculty Scholarship at Chicago Unbound. It has been accepted for inclusion in Journal Articles by an authorized administrator of Chicago Unbound. For more information, please contact unbound@law.uchicago.edu. 


\title{
The Questionable Empirical Basis of Article 2's Incorporation Strategy: A Preliminary Study
}

\author{
Lisa Bernstein $\dagger$
}

\begin{abstract}
The Uniform Commercial Code, ${ }^{1}$ the Convention on Contracts for the International Sale of Goods, ${ }^{2}$ and the modern Lex
\end{abstract}

$\dagger$ Professor of Law, University of Chicago. I would like to thank my research assistants Marc Blitz (silk), Richard Welch (hay), Drew Porter (coffee), Andrea Adelman and Deborah Healy (grain and feed), Mary LaBrec (textiles), as well as Connie Fleischer, Bill Schwesig, Chuck Ten-Brink, David Barrett, Carmen Abber, and Lorrie Ragland. I would also like to thank Omri Ben-Shahar, Yoram Barzel, Lucian Bebchuk, Edward Bernstein, Brian Bix, David Charny, Dick Craswell, Richard Epstein, Clay Gillette, Victor Goldberg, Jack Goldsmith, Philip Hamburger, Alon Harel, Claire Hill, Ehud Kamar, Alan Kamp, Louis. Kaplow, Avery Katz, Dan Klerman, Doug Lichtman, Ronald Mann, Ed Morrison, Dennis Patterson, Eric Posner, Richard Ross, Keith Sharfman, Steve Shavell, Alex Stein, Cass Sunstein, Bill Vulkovitch, Jim Whitman, Eyal Zamir, and participants at the Northwestern University Law School Symposium on Relational Contracting, Harvard Law and Economics Workshop, University of Montreal Law School Workshop, Columbia Law School Law and Economics Workshop, Berkeley Law and Economics Workshop, University of Virginia Faculty Workshop, American Law and Economics Association Annual Meeting (Contract Law Panel), Law and Society Association Annual Meeting, and The University of Chicago Law Review Symposium Formalism Revisited for helpful comments or discussions. This research is part of a larger project on private commercial law that is sponsored by NSF Grant SBR-9422795. Additional funding was provided by the University of Chicago Law School.

2 This Article focuses solely on UCC Article 2 as supplemented by the relevant parts of Article 1. UCC $\S \S 1-2$ (West 14th ed 1995). The incorporation principle is expressed in the Code sections dealing with course of dealing and usage of trade, id at $\S 1-205$, and course of performance, id at $\S 2-208$, as well as in the Code's definition of "Agreement," which includes "the bargain of the parties in fact as found in their language or by implication from other circumstances including course of dealing or usage of trade or course of performance." Id at $\S 1-201(3)$. It is also at the heart of the Code's duty of good faith, which requires that merchants act in accordance with "the observance of reasonable commercial standards of fair dealing in the trade," id at $\S 2-103(b)$, which is to be "further implemented by Section 1-205 on course of dealing and usage of trade, id at $\S 1-203 \mathrm{cmt}$, as well as the Code's interpretive approach, which directs courts to determine "the meaning of the agreement of the parties ... by the language used by them and by their actions, read and interpreted in light of commercial practices and other surrounding circumstances. The measure and background for interpretation are set by the commercial context, which may explain and supplement even the language of formal or final writing." Id at $\S 1-205 \mathrm{cmt} 1$. See also id at $\S 2-301 \mathrm{cmt}$ ("In order to determine what is in accordance with the contract' under this Article usage of trade, course of dealing and performance, and the general background of circumstances must be given due consideration."). The incorporation principle is also embodied in numerous Code provisions and Official Comments that direct courts to take into account "usages of trade," "commercial standards," "the law merchant," and other aspects of the contracting context in filling gaps. See generally the obligations in UCC Art 2, Part 3 ("General Obligation and Construction of Con- 


\section{Mercatoria ${ }^{3}$ are based on the premise that unwritten customs and} usages of trade exist and that in commercial disputes they can, and should, be discovered and applied by courts. ${ }^{4}$ The existence of commercial customs that can be discovered and codified by diligent observers is also at the heart of some proposals for creating commercial law in developing or formerly socialist countries. ${ }^{5}$

tract ${ }^{n}$ ), and its associated Official Comments. Less noticeably, and typically ignored by commentators, the incorporation strategy, in the form of explicit references to usages of trade, commercial standards, and commercial context, as well as references to what is commercially reasonable, seasonable, and commercially impracticable, also runs through numerous Code provisions (as explicated by their associated Official Comments) that might broadly be termed "traffic rules" and that unlike gap fillers are, as a practical matter, difficult, if not impossible, to negate. See generally UCC Art 2, Part 2 ("Form, Formation and Readjustment"); Part 5 ("Performance"); Part 6 ("Breach, Repudiation and Excuse"); Part 7 ("Remedies"). Finally, most generally, one of the stated "[u]nderlying purposes" of the Code is "to permit the continued expansion of commercial practices through custom, usage and agreement of the parties." UCC $\$ 1-102$.

2 See, for example, United Nations Convention on Contracts for the International Sale of Goods ("CISG") Art 9(2) (1980), reprinted in United Nations, Conference on Contracts for the International Sale of Goods, 19 ILM 671, 674 (1980) ("The parties are considered, unless otherwise agreed, to have impliedly made applicable to their contract or its formation a usage of which the parties knew or ought to have known and which in international trade is widely known to, and regularly observed by, parties to contracts of the type involved in the particular trade concerned.").

3 The term lex mercatoria is generally understood to include international conventions on the sale of goods and written compilations of custom like the Incoterms (see note 139), as well as unwritten customs and practices that are either specific to a particular trade or are applicable to all commercial transactions. See, for example, Harold J. Berman and Felix J. Dasser, The "New" Law Merchant and the "Old:" Sources, Content, and Legitimacy, in Thomas E. Carbonneau, ed, Lex Mercatoria and Arbitration: A Discussion of the New Law Merchant 21-36 (Transnational Juris 1990) (discussing the customary basis of the lex mercatoria); Keith Highet, The Enigma of the Lex Mercatoria, in Carbonneau, ed, Lex Mercatoria 99, 104-05 (same).

- This Article's discussion of the UCC focuses nearly exclusively on disputes between merchants. Early drafts of the Code provided for the use of either arbitrators or merchant juries to determine the content of trade usages and other commercial standards. See, for example, National Conference of Commissioners on Uniform State Laws, Report and Second Draft: The Revised Uniform Sales Act $\$$ 59(I)(a), (d) at 254 (1941) (setting out matters to be submitted to merchant experts, including the effects on obligations of "mercantile usage" or "usage of trade," whether tender was conforming, whether an action was reasonable, or any other "issue which requires for its competent determination special merchants' knowledge rather than general knowledge"). The failure to include a merchant jury provision in the final Code was due to a need to obtain political support for the proposed Code, not to Llewellyn's abandonment of the concept. See Zipporah Batshaw Wiseman, The Limits of Vision: Karl Llewellyn and the Merchant Rules, 100 Harv I Rev 465, 527-29 (1987). Most of the objections to the incorporation strategy put forth in this Article, however, would not be weaker if a merchant jury provision had been included because they are not based primarily on the limits of courts' institutional competence.

s See, for example, Paul H. Rubin, Growing a Legal System in the Post-Communist Economies, 27 Cornell Intl I J 1, $42-45$ (1994) (suggesting that trade associations should be formed to interpret and enforce contracts according to commercial custom so that, over time, customs will become sufficiently well developed to supply the basic principles of a public commercial law). See also Anthony T. Kronman, Contract Law and the State of Nature, 1 J L Econ \& Org 5 (1985) (discussing private mechanisms for contract enforcement); 
More broadly, the idea that courts in deciding cases should look to immanent business norms, consisting of both the practices of contracting parties and unwritten customs, is a fundamental tenet of the legal realist approach to contract interpretation, an approach that was developed, championed, and ultimately codified by Karl Llewellyn, a leading legal realist and the principal drafter of Article 2 of the Uniform Commercial Code ("Code"). ${ }^{6}$

Academic commentators have long debated the proper role of customary practices in commercial adjudication. ${ }^{7}$ They have explored the difficulty of defining the parameters of the custom to be sought, ${ }^{8}$ have debated the efficiency of custom, ${ }^{9}$ have explored the actual role played by custom in various adjudicatory fora ${ }^{10}$ have discussed the extent to which custom was absorbed into the common law, ${ }^{11}$ and have noted the problems of institutional com-

Robert D. Cooter, Decentralized Law for a Complex Economy: The Structural Approach to Adjudicating the New Law Merchant, 144 U Pa L Rev 1643 (1996) (suggesting that as the economy increases in complexity it becomes increasingly important for courts to enforce certain types of business custom). Similarly, commentators have suggested looking to usages of the trade to set standards for electronic commerce. See, for example, Alejandro E. Almaguer and Roland W. Baggott III, Shaping New Legal Frontiers: Dispute Resolution for the Internet, 13 Ohio St J Disp Res 711, 714, 716 (1998) (advocating the use of "Self Regulatory Mechanisms [to] Promote a "Cyber-Usage of Trade," because, "[i]n the age of mature electronic commercial transactions, parties must be able to rely on custom and usage of trade").

- See generally William Twining, Karl Llewellyn and the Realist Movement chs 11-12 (Weinenfeld \& Nicolson 1973). See also Richard Danzig, A Comment on the Jurisprudence of the Uniform Commercial Code, 27 Stan I Rev 621, 624 (1975) ("Llewellyn saw law as an articulation and regularization of unconsciously evolved mores-a crystallization of a generally recognized and almost indisputably right rule ( $a$ 'singing reason'), inherent in, but very possibly obscured by, existing patterns of relationships.").

7 There is no widely accepted definition of a custom. This Article defines it as an unwritten practice that would be considered a usage of trade under the Code, see UCC \& 1205 , or the type of commercial standard that would be incorporated into a contract or taken into account in the contract interpretation process under the Code. See note 1 . This Article uses the terms trade practice, usage of trade, and custom interchangeably.

- See, for example, Richard Craswell, Do Trade Customs Exist?, in Jody S. Kraus and Steven D. Walt, eds, The Jurisprudential Foundations of Corporate and Commercial Law (Cambridge 1999).

- See, for example, Eric A. Posner, Law, Economics, and Inefficient Norms, $144 \mathrm{U} \mathrm{Pa}$ I Rev 1697 (1996) (providing a host of reasons why norms might not be efficient); Jody S. Kraus, Legal Design and the Evolution of Commercial Norms, $26 \mathrm{~J}$ Legal Stud 277 (1997) (drawing on a theory of cultural evolution to argue that customary practices are unlikely to be efficient but may be more nearly optimal than either individual decisions with respect to particular transactions or legislative enactments).

${ }^{10}$ See, for example, Christopher R. Drahozal, Commercial Norms, Commercial Codes, and International Commercial Arbitration (1999) (unpublished manuscript on file with U Chi L Rev).

"See, for example, E. Karl McGinnis, Present Legal and Practical Methods by which Business Custom is Enforced, 5 NC L Rev 136 (1927) (discussing various ways of "enforcing" custom including trade association arbitration and incorporation into the common law). 
petence that might inhibit the accurate determination of the content of customary practices. ${ }^{12}$ However, a more basic and naturally prior question has not been adequately addressed. Namely, to what extent do the types of industry-specific meanings of words and the types of unwritten, industry-wide "usages of trade" and "commercial standards"- that the Code directs courts to incorporate into commercial agreements through both gap filling and the interpretive process-actually exist as to most aspects of contracting relationships in merchant communities? ${ }^{13}$

\footnotetext{
${ }^{12}$ See, for example, Randy E. Barnett, The Sound of Silence: Default Rules and Contractual Consent, $78 \mathrm{Va}$ L Rev 821, 908 n 231 (1992) (noting that "while judges may be good surrogates for the rationally ignorant consumer, they are often deficient interpreters of more specialized usages of trade”).

${ }^{13}$ The Code was assumed to be based on a solid empirical foundation. William A. Schnader, a primary mover behind the Code project, chose Karl Llewellyn as Chief Reporter because
}

[n]ot only was Professor Llewellyn a student of commercial law as it appeared in the law books, but he was the type of law professor who was never satisfied unless he knew exactly how commercial transactions were carried on in the market place. He insisted that the provisions of the Code should be drafted from the standpoint of what actually takes place from day to day in the commercial world rather than from the standpoint of what appeared in statutes and decisions.

William A. Schnader, A Short History of the Preparation and Enactment of the Uniform Commercial Code, 22 U Miami L Rev 1, 14 (1967) (UCC Symposium). However, with the exception of seeking (and then ignoring) the opinions of merchants in hearings on the Code (see note 146 and text accompanying notes 144-47), rigorous empirical research into what types of rules would actually be responsive to merchant concerns was never undertaken. While Llewellyn's defenders recognize that the lack of an empirical basis for the Code was inconsistent with his realist and scientific approach to law as well as his oftenexpressed position that in drafting a commercial code attention should be paid to the "wide basis of established commercial experience," Twining, Karl Llewellyn at 524 (cited in note 6), they are quick to point out that "critics who have been suspicious of Llewellyn's alleged 'unscientific', 'impressionistic' or 'anecdotal' approach to facts have yet to point to any major factual assumptions of the Code that were misleading or inaccurate. Nor have suggestions been forthcoming as to specific empirical research that might have been worth doing." Id at 319. See also the comment of Robert Summers in id at 467 ("I think the biggest and best reason for lack of empirical research is this: most of the law is 'suppletive' law-it applies only when the parties have not agreed as to the matter in hand. It says what the law is when the parties don't say."). This Article, together with earlier work on other industries, see Lisa Bernstein, Merchant Law in a Merchant Court: Rethinking the Code's Search for Immanent Business Norms, 144 U Pa L Rev 1765 (1996), and Lisa Bernstein, Private Commercial Law in the Cotton Industry: Value Creation Through Rules, Norms, and Institutions (Sept 8, 1998) (unpublished manuscript on file with U Chi L Rev), suggests that the lack of solid empirical research led Code drafters to adopt provisions that are detrimental rather than accommodating to merchant concerns, and to a commercial law based on a deeply flawed understanding of merchant reality.

It should be noted that Llewellyn was aware of the sources discussed in this Article. In a memorandum he presented in defense of the proposed Code's battle of the forms provision, UCC $\$ 2-207$, he cited the existence of similar provisions in merchant trade rules in support of his position; yet when these sources did not support the position he was advocating, Llewellyn neglected to mention them. Karl N. Llewellyn, Memorandum by K.N. Llewellyn Replying to the Report and Memorandum of Task Group 1 of the Special Com- 
Starting from the generally accepted premise that unwritten commercial customs are most likely to arise and endure in situations where transactors interact on a repeat basis, over a long period of time, in relatively similar transactions, ${ }^{14}$ this Article addresses the question from a largely empirical perspective. ${ }^{15}$ In

mittee of the Commerce and Industry Association of New York, Ine., on the Uniform Commercial Code, in Study of Uniform Commercial Code Memoranda presented to the Commission and Stenographic Report of Public Hearing on Article 2 of the Code 42, 56-57 (1954), reprinted in State of New York, 1 Report of the Law Revision Commissioner for 1954 and Record of Hearings on the Uniform Commercial Code 106, 121 (Williams 1954). In addition, Llewellyn's early writings show that he was aware of the existence of these private legal systems. See, for example, Karl N. Llewellyn, The Effect of Legal Institutions Upon Economics, 15 Am Econ Rev 665, 672, 673 n 24 (1925) ("Increasingly, associations are forming which adopt their own rules of action and even settle their own disputes .... And the rules which ... such associations lay down and apply, are part of the body of our law. *** [T] he association-made rules are like enough to law to deserve careful attention.").

${ }^{14}$ These preconditions for the emergence of custom are widely accepted. Several additional factors, such as that the transactors play reciprocal roles in the transaction (in the commercial law setting this means that they are buyers one day and sellers the next), and that most transactions are among members of an ethnically homogeneous or geographically concentrated small group, are said to make the emergence of custom more likely but are not strictly required. For endorsements of these criteria, see Richard A. Epstein, The Path to The T.J. Hooper: The Theory and History of Custom in the Law of Tort, $21 \mathrm{~J}$ Legal Stud 1, 11-16 (1992) (" $[T]$ he key variables on the emergence of custom seem to be the symmetry of results and the frequency of the dispute with the question of severity of the loss playing a secondary role."); Bruce L. Benson, Customary Law as a Social Contract: International Commercial Law, 3 Const Pol Econ 1, 7 (1992) (endorsing these criteria as corresponding to the game theoretic conditions for the emergence of commercial custom and cooperation). See also Robert C. Ellickson, Order without Law: How Neighbors Settle Disputes (Harvard 1991). Although the merchant industries discussed in this Article do not perfectly fulfill the conditions theorists identify as being ideal for the emergence of custom, they come far closer to doing so than most contemporary industries whose disputes are adjudicated under the Code's merchant rules.

${ }_{15}$ Most commentators simply assert or assume the existence of custom. See, for example, Berman and Dasser, The "New" Law Merchant at 28, 32 (cited in note 3) ("Yet, that should not stop us from seeing what is right in front of our noses! It is the factual existence of international custom and its continuous use ... that allows us to speak of international trade as a special type of international law. $* *$ Nobody denies that there is a body of international rules, founded on the commercial understandings and contract practices of an international community principally composed of mercantile, shipping, insurance, and banking enterprises of all countries."); id at 25 ("[C]ustomary commercial understandings enjoy almost total recognition .... [notwithstanding the fact that] [s]uch rules may not be very conspicuous and may easily be overlooked by scholars."). The only notable exceptions are Jack $\mathrm{L}$. Goldsmith and Eric A. Posner, A Theory of Customary International Law, 66 U Chi L Rev (forthcoming 1999) (drawing on game theoretic models and fact-based case studies to suggest that customary international law does not exist); Craswell, Do Trade Customs Exist? (cited in note 8) (questioning whether trade customs can be given content by adjudicators independent of "the goals, beliefs and other normative premises of the person doing the identifying," and concluding that they cannot because the problems faced by a court "finding" the content of a custom are analytically similar to the problems faced by a court trying to find the content of the common law). See also Leon E. Trakman, The Law Merchant: The Evolution of Commercial Law 45-60 (Fred B. Rothman 1983) (attempting to empirically establish the existence of custom in interna- 
keeping with Llewellyn's view that commercial law should reflect merchant reality ${ }^{16}$ it identifies several merchant industries-hay, grain and feed, textiles, and silk - that in an early stage of their development were roughly characterized by conditions favorable to the emergence of customs. It then explores the attempts of national trade associations in these industries to codify their industries' customs into written trade rules.

The debates surrounding these codification efforts suggest that there was not widespread agreement among merchants as to either the meaning of common terms of trade or the content of many basic commercial practices. Rules committee debates sometimes went on for years, customs relating to important aspects of transactions were left uncodified because consensus could not be achieved, and in most industries drafting committees eventually engaged in only selective codification. In addition, over time, many associations came to explicitly concede that they were attempting to change rather than merely incorporate existing practices.

These findings, together with interview evidence and the testimony of merchant associations on the proposed Commercial Code, suggest that "usages of trade" and "commercial standards," as those terms are used by the Code, may not consistently exist, even in relatively close-knit merchant communities. While merchants in the industries examined here sometimes do and did act in ways amounting to loose behavioral regularities, most such regularities are either much more geographically local in nature or far more general in scope and conditional in form than is commonly assumed. ${ }^{17}$ These industries' efforts at codification, and the

tional oil contracts). But see Chris Williams, The Search for Bases of Decision in Commercial Law: Llewellyn Redux, 97 Harv L Rev 1495, 1501-04 (1984) (book review) (arguing that Trakman's evidence does not establish the existence of custom).

${ }^{16}$ See, for example, Walter D. Malcolm, The Proposed Commercial Code: A Report on Developments During the Period from May 1950 through February 1951, 6 Bus Law 113, 126 (1951) (quoting the Report of the Committee on the Proposed Commercial Code: "the practices of businessmen and business houses are important factors in construing their contracts and actions and in determining their rights and liabilities .... [M]any of the changes effected by the Code are designed to adapt rules of law to the way that business is actually carried on"). See also National Conference of Commissioners on Uniform State Laws, Report and Second Draft: The Revised Uniform Sales Act \$ 59 at 253 (cited in note 4) (noting, in a comment thought to have been drafted by Llewellyn, that while "the law about the effect of 'business custom' is quite ... uncertain ... [t]hat has not been because any sane Court has for half-a-century doubted the wisdom of fully incorporating the relevant usage of trade into the agreement and into the decision on adequacy of performance").

${ }^{17}$ Although commentators have long recognized local differences in customary practices, many have dismissed them as trivial without providing any supporting examples. See Benson, 3 Const Pol Econ at 15 \& $n 9$ (cited in note 14) (arguing that the law mer- 
subsequent operation of modern merchant-run private legal systems, also suggest that merchants differentiate between written and unwritten customs and that their understanding of customary practices is both different from and far more nuanced than Llewellyn's.

The understanding of merchant reality gained by looking at these codification debates, together with other merchant-related sources, suggests that given the Code's flawed empirical basis, it may be time to reconceptualize the role played by custom in commercial transactions and to rethink the wisdom of the Code's incorporation-based approach to gap filling and contract interpretation, ${ }^{18}$ an approach that is endorsed and strengthened in current drafts of proposed revisions to the Code,${ }^{19} \mathrm{drafts}$ that represent the undeserved triumph of legal realism in commercial law.

To this end, this Article proposes an alternative conception of the types of customs and practices that do exist and the role they play in commercial relationships. It suggests that while the types of generally agreed-upon practices that Llewellyn thought merchants viewed as supplying implicit contract provisions do not consistently exist, merchants do consider it valuable to have an understanding of the ways transactions are usually done, an un-

chant protected merchants "against the vagaries of local laws and customs," thereby recognizing the existence of these differences, but dismissing them as "reflect[ing only] differential preferences for relatively minor variations and commercial practices and institutions").

${ }^{18}$ Merchant tribunals' rejection of the incorporation strategy does not necessarily undermine the "situation sense" component of Llewellyn's jurisprudence. See generally James Whitman, Commercial Law and the American Volk: A Note on Llewellyn's German Sources for the Uniform Commercial Code, 97 Yale I J 156 (1987) (describing the origins and content of Llewellyn's notion of situation sense). The opinions produced by merchant tribunals reveal that arbitrators' background knowledge of the trade may enable them to better assess the credibility of testimony and may give them a better understanding of the types of evidence that ought to be submitted. Because most merchant legal systems authorize arbitrators to request additional information in lieu of giving the parties a right of discovery, arbitrators' background understanding of transactional practices should enable them to intelligently exercise this authority.

${ }^{19}$ See Permanent Editorial Board for the Uniform Commercial Code, PEB Study Group, Uniform Commercial Code Article 2: Preliminary Report 16-17 (1990) (After reviewing the present Code's incorporation strategy and its use of open-ended terms like "reasonable" and "seasonable," the Study Group "endorses the drafting style utilized in Article 2 and recommends that the general sales policies . . . be retained. . . . We recommend that the Drafting Committee consider ways beyond those recommended by the Study Group to articulate these policies and to improve their implementation. The objective is to achieve a more complete utilization of them by the parties and the courts in the resolution of commercial disputes."). See also id at 9, 32 (emphasizing that the Code's provision on course of dealing and usage of trade "is a crucial component of the [Code's] broad definition of agreement," and recommending that the section on course of performance or practical construction be moved to Article 1, because "[t]his important principle of interpretation should not be limited to contracts for the sale of goods"). 
derstanding gleaned from a rough aggregation of practices in the market as a whole. It then argues that these types of understandings, which this Article refers to as weak-form customs, provide transactors with a pool of common knowledge that in the early stages of their contracting relationship enables them to better assess whether the other transactor is a cooperator or a defector, thereby facilitating the emergence and maintenance of repeat-dealing cooperative contracting relationships. On this view, weak-form customs, which are different from the strong-form Hayekian customs ${ }^{20}$ whose existence is assumed by the Code, can be understood as providing transactors with a set of vaguely defined yet workable relationship-creating norms that initially add tremendous value to contracting relationships but that gradually diminish in importance as contracting relationships mature.

Part I of this Article looks at several associations' attempts to codify custom and discusses the methodological limitations of drawing conclusions from the codification debates. Part II briefly revisits and critiques the justifications that have been developed for the incorporation strategy. Part III proposes a theory of the relationship-creating role played by weak-form customs in commercial transactions. It then provides suggestive, though not conclusive, evidence that it is both a plausible and analytically useful account of merchant interactions. Part IV concludes that while some industry-wide usages of trade do exist, and highly local customs might have existed, the pervasive existence of usages of trade and commercial standards, whose geographic reach is coextensive with the reach of the relevant trade, is a legal fiction rather than a merchant reality. It therefore suggests that new justifications for the Code's interpretive approach and gap-filling methodology are needed.

\section{Trade Associations' AtTEMPts to Codify Custom}

Between 1860 and the mid-1900s, a period during which many merchant industries had already become significantly national in scope, numerous national trade associations created private arbitration tribunals and soon thereafter began to codify industry practices into written trade rules. ${ }^{21}$ These rules typically state that they are either codifications ${ }^{22}$ or selective codifications

\footnotetext{
20e notes 176-77 and accompanying text.

${ }^{21}$ For an overview of the operation of these private legal systems that includes a discussion of their substantive rules, adjudicative procedures, and adjudicative approaches, see Lisa Bernstein, Private Commercial Law, in Peter Newman, ed, 3 The New Palgrave Dictionary of Economics and the Law 108 (Stockton 1998).

${ }^{22}$ See, for example, The American Yarn Spinners Association, Inc ("AYSA"), The Yarn
} 
of industry customs, ${ }^{23}$ or attempts either to clarify, or to achieve uniformity in, industry practices. ${ }^{24}$ The preambles to many sets of trade rules explicitly state that their goal is to reduce the number of commercial misunderstandings that arise by clarifying the scope and content of contractual obligations..$^{25}$ In most industries, these trade rules provide a detailed set of contract default rules covering most aspects of contract formation, performance, and breach.

In most associations, trade rules are drafted and subsequently amended by committees of experienced industry members who serve without compensation and are either appointed by the board of directors or directly elected by the membership. In many industries, both the original rules and subsequent amendments are subject to floor debate at the associations' annual conventions ${ }^{26}$ and must be approved by a specified percentage of the membership as a whole. ${ }^{27}$

Rules of 1989 Introduction (AYSA 1989) ("For more than fifty years, members of the Yarn industry have utilized industry rules regarding contract terms and conditions and industry norms for the sale of yarns. The Yarn Rules have been used as a statement of trade practice and from time to time have been revised to reflect developments in the industry over the years. The Yarn Rules and the customary contract terms are recommended to serve as a reference to members of the yarn industry of trade practices commonly in use throughout the industry.").

${ }^{23}$ See, for example, Rubber Trade Association of New York, Inc, General Rules Prefatory Note (revised 1978) ("The compilation is the result of a study of the usages and customs that have developed in the trade and, in the opinion of the Association, is representative of those terms and conditions of sale which will eliminate misunderstandings between buyer and seller.").

${ }^{24}$ See, for example, American Fats and Oils Association, Inc, By-Laws Art I, "Purpose," reprinted in American Fats and Oils Association, Inc, Trading and Arbitration Rules Bylaws, Roster (1994) ("to work toward uniformity and certainty in ... the customs and usages of the trade"); Association of Food Industries, Inc, Fact Sheet "Objectives" (no publication date) ("To seek uniformity and certainty in the customs and usage of the trade."); The Cocoa Merchants' Association of America, Inc, By-Laws Art II, "Purpose" (revised Oct 29, 1993) ("to procure uniformity and certainty in the customs and usage of the trade"); Charter and By-Laws of the Greenwood Cotton Exchanges Charter No 7 (1957) ("to establish ... uniform usages, rules and regulations"); Charter Constitution and By-Laws of the Memphis Cotton Exchange 5 (1992) ("to maintain uniformity in its rules, regulations and usages"); American Seed Trade Association ("ASTA"), Bylaws Art I, "Purposes" (as amended Apr 15, 1989) (to "assist in the promulgation of trade rules, practices and customs for those engaged in the industry"); Association of Crafts and Creative Industries, Bylaws Art II, "Objectives" §§ 1-2 (1994) (to "foster equity and business usages ... [i]n furtherance of these purposes ... the Association shall have power *** [t]o advance lawful and fair trade practices, customs and usages").

${ }^{25}$ See, for example, American Peanut Shellers Association, Official Trading Rules: Farmers Stock, Domestic and Export 2 (May 1994) (noting that the rules were adopted to "make more definite the terms of contracts of purchase and sale"). See also note 33.

${ }^{25}$ See, for example, National Hay Association, Report on the Twelfth Annual Convention (1905) (reporting debates verbatim). Other associations mail copies of proposed changes to their members or print proposed changes in trade publications.

${ }^{27}$ Many by-laws also give each member firm (regardless of its size) one vote on pro- 
This Part explores the efforts of trade associations in core merchant industries to codify their commercial customs into trade rules. It finds that, contrary to the assumptions of the Code drafters, even in close-knit communities merchant transactors do not, except within very local spheres ${ }^{28}$ or in very general ways, have similar views about the meaning of common contractual terms or the content of precisely those types of commercial standards and usages of trade that the Code and its Official Comments direct courts to take into account in deciding cases.

\section{A. Hay}

The National Hay Association ("NHA") ${ }^{29}$ was formed in $1895 .^{30}$ It began arbitrating cases in $1899^{31}$ and adopted its first

posed trade rules. At the National Grain and Feed Association ("NGFA"), trade rules may be temporarily amended by a vote of two-thirds of the Board of Directors, Bylaws of the NGFA Art XVIII, \& 2, reprinted in NGFA, NGFA Trading and Trade Rules Seminar (1994) (no pagination in original), subject to "an affirmative vote of two-thirds of the voting power present at the next annual meeting of the Members," id at $\S 1$ (see also id at § 3), with each "Active member and each Affiliated member ... entitled to one vote," id at Art IV, $\S 1$ (see also $\S 2$ ). In associations with this voting structure, even if large firms control the rules committees, it will be difficult for them to secure passage of rules that are greatly biased in their direction. On the other hand, if they do control most committees, small firms would have a hard time even getting the rules they might want onto the agenda. It is, however, important to note that in some associations, proposed rules and rules amendments must be approved by a sellers' group and a buyers' group. See, for example, American Textile Manufacturers Institute, Inc ("ATMI) and American Cotton Shippers Association ("ACSA"), The Southern Mill Rules for Buying and Selling of American Cotton 32 (ATMI \& ACSA 1995) (requiring the approval of members of the ACSA and the ATMI).

Most by-laws provide for annual review of the trade rules, but the actual frequency of rules amendments varies widely. See NGFA, Trade Rules and Arbitration Rules 3 (pamphlet) (1995) (noting that the Grain Rules were amended fifty-nine times and the Feed Rules thirty-three times). See also note 84 (Worth Street Rules) and notes 116, 120, and 122 (silk rules).

${ }^{26}$ In the context of the incorporation debates, there are also reasons to be skeptical about strong statements suggesting that local customs exist. If, for example, a transactor is arguing for adoption of a particular rule (especially one that is favorable to his locality rather than simply to a subset of firms in it), he might invoke the alleged universality of the practice in his locality to give his argument legitimacy and persuasive force.

${ }^{2}$ The NHA is "made up of producers, dealers, brokers and representatives of related industry.... [It] is dedicated to the development and maintenance of better quality hay and improved marketing practices." NHA, National Hay Association (Association brochure mailed to author in 1997).

${ }^{30}$ At the time the NHA was formed, the interstate trade in hay was fairly wellestablished, having begun in the 1840s. See William J. Reinke, Arbitration in the National Hay Association 2 (1955) (unpublished Ph.D. dissertation, University of Chicago, on file with the University of Chicago Libraries) ("The shipment and marketing of hay is reported to have originated in the $1840^{\circ}$ s.").

s1 In 1897, a by-law amendment to provide for arbitration was proposed and apparently was adopted. NHA, Report of the Fourth Annual Meeting 46 (1897). Full Association records from 1898 to 1900 are unavailable, but the amendment appears in the 1901 Con- 
set of trade rules in 1907, after two years of work on the project..$^{32}$ The goal of the rules creation process was not to memorialize already uniform customary practices, but rather to prevent disputes by actively promoting uniformity. ${ }^{33}$ Prior to the adoption of the rules:

$[P]$ acking, shipping and handling hay was an irregular business. There were no established customs to govern, and every transaction was typical of the parties engaged in it. Balers and shippers followed the bent of their own inclination in the details of baling, weighing, buying and shipping, and distributing markets also points of consumption, were under local influences and often dominated by whimsical notions, and at the same point of shipment, or in the same receiving market there was irregularity of method or consistency in business. ${ }^{34}$

In fact, hay transactors were not even able to agree on the meaning of trade terms as basic as "bale" and "No. 1 Hay." As one industry participant noted:

What is a bale of No. 1 hay? There is not a man in this room who can tell you. Put twenty bales of different grades of hay along that room, and there will not be five men among you who will agree. You have decided that a ton of No. 1 hay may contain not over one fifth of tame grasses. A gentlemen spoke up and said as his opinion that tame grass is clover. If you know anything, you know that a bale of hay with one-

stitution and By-Laws, Art XIV(2), reprinted in NHA, Report of the Eighth Annual Meeting 48 (1901), and the 1899 Report contains a lament that the "Committee on Arbitration and Investigation has little power," suggesting that the arbitration amendment had been adopted. NHA, Report of the Sixth Annual Meeting 185 (1899). Prior to the Arbitration Committee, the Association created an Investigation Committee that was empowered to investigate and sanction instances of "uncommercial conduct." NHA, Constitution and ByLaws Art X, reprinted in NHA, Report of the Second Annual Meeting 32 (1895). The work of this Committee continued even after the Arbitration Committee was formed.

${ }^{32}$ NHA, Report of the Eleventh Annual Convention 154-55 (1905) ("I move that the incoming President appoint a committee of five to draft trade rules governing the contracts for the purchase and sale of hay.").

${ }^{*}$ See NHA, Report of the Twelfth Annual Convention 170 (1906) ("[D]isputes are more apt to arise, owing to misunderstandings than to anything else. I think a majority of the people mean to do right, but misunderstandings will creep in. Therefore it seems very important that this Association should have trade rules."). See also NHA, Constitution and By-Laws "Preamble," reprinted in NHA, Report of the Second Annual Meeting 29 (1895) (declaring that a goal of the association is to "use our best efforts to have established and maintained uniformity in commercial usages and in the grades of hay and straw in the different markets of the country"); NHA, Constitution "Preamble," reprinted in NHA, Report of the Eighth Annual Meeting 42 (1901) (reaffirming the Association's commitment "to use our best efforts to have established and maintained uniformity in commercial usage").

${ }^{3}$ NHA, Report of the Eighteenth Annual Convention 3 (1911). 
fifth clover is clovery mixed hay. No. 1 hay should be pure timothy. ${ }^{35}$

And, as another observed:

The large bales of New York and New England means a different bale from the large bale in the Western States, and the same is true of the small bales. In Chicago at present there is a lack of clear definition of small bales. ${ }^{36}$

The debates surrounding the adoption and amendment of the hay rules also suggest that there were no agreed-upon usages in relation to some of the precise aspects of a standard transaction that the Code and its Official Comments explicitly direct courts to discern by reference to usage of trade or commercial standards.

For example, the Code provides that when the time for "delivery or any other action under a contract" is not specified, it "shall be a reasonable time," ${ }^{\text {"37 }}$ determined by reference to "com-

${ }^{25}$ NHA, Report of the Fourth Annual Meeting 40 (1897). See also NHA, Report of the Twenty-Seventh Annual Convention 54 (1920) ("[T]here is at present no uniform grade or at least no uniformly interpreted grade that can be used as a medium for making sales or purchases of hay in territories remote from each other. What is considered as No. 1 timothy, for example, in one producing section may be considered as No. 2 timothy in another producing section, and still of another grade in the consuming section to which it may be shipped."); NHA, Report of the Eighteenth Annual Convention 154 (1911) ("The hay trade of this country will not be on a sound basis, on an honest basis, until No. 1 hay is No. 1 hay East, West, North, and South."); NHA, Report of the Twelfth Annual Convention 37 (1905) ("Grades cannot be expected to suit the South, North, East and West with the same degree of satisfaction."). Disputes over grade were not due merely to subjective disagreements about quality assessments, but rather were due, in part, to the fact that different markets defined the same grade differently. NHA, Report of the Twenty-Eighth Annual Convention 70-75 (1921) (recounting a long debate as to whether "Choice" hay or No. 1 hay is the highest grade, with some participants questioning whether "Choice" was even a recognized grade designation); NHA, Report of the Twenty-Seventh Annual Convention 74-77 (1920) (comparing the grading requirements of eleven sets of association and exchange grading rules and finding wide differences).

${ }^{36}$ NHA, Report of the Tenth Annual Convention 76 (1903). See also id at 80 ("[B]ales are not governed by size so much as by weight in the Northwest. In Chicago, I know, they like light bales, weighing from eighty-five to ninety-five pounds; and in the East they like heavier bales. In Wisconsin they will put in 125 to 135 pounds, and that makes a pretty heavy bale."); NHA, Report of the Fourteenth Annual Convention 72 (1907) ("[T]here is no general definition of the terms as a Small Bale in one section may mean a Medium Bale in another, or a Medium Bale a Small Bale in another, a Medium Bale a Large Bale in another and so on."). The causes of this disagreement were partly technological since different hay baling machines produced different size bales of hay. Similar disagreements existed in other industries. See, for example, ASTA Yearbook 59 (1914) ("Seedsmen handle large quantities of ... seeds ... for few of which legal weights per bushel have been established. They have, therefore, to arrive at customary weights only, which vary in the different States.") (emphasis added). The weight associated with the designation "bale" in the silk industry also varied from country to country. See Revision of Raw Silk Rules Completed, 3 Silkworm 76 (May 1921).

" UCC \& 2-309. 
mercial standards," "acceptable commercial conduct," and "usage of trade. ${ }^{338}$ However, the debate over a proposed rule, which would determine when certain freight charges had to be requested, reveals that there was no agreement as to what a reasonable time might be. ${ }^{39}$ As one participant opined, "that 'reasonable time' business will not [tell] anything. You might as well leave it out." ${ }^{\prime \prime 0}$ And, in response to a suggestion that a more definite rule be adopted, one transactor proposed "nine months," another "fifteen days," and still another, "within ten days after the freight bills have been paid."

Prior to adoption of the rules, there was also widespread disagreement about the meaning of the type of common contractual language that the Code and its Official Comments direct courts to interpret "as meaning what it may fairly be expected to mean to parties," which is determined, in part, by looking to "usage of trade as a factor in reaching the commercial meaning." $\$ 2$ For example, while hay contracts tended to include delivery time provisions like "prompt" or "immediate," provisions the Code would look to usage to define,${ }^{43}$ there was no consensus as to what

${ }^{3}$ Id at $\$ 2-309 \mathrm{cmt} 1$. See, for example, Superior Boiler Works, Inc $v$ R.J. Sanders, Inc, 711 A2d 628, 636 (RI 1998) ("In the usual case the question of what constitutes a reasonable time under the UCC is one for the finder of fact to determine from ... [several factors, including] usages of trade in the pertinent industry."); Jamestown Terminal Elevator, Ine v Hieb, 246 NW2d 736, 740 (ND 1976) (holding that "based on the previous 'course of dealing' of the parties and the industry's 'usage of trade', the jury could determine that August 31, 1973, was a 'reasonable time' for delivery").

ss See NHA, Report of the Sixteenth Annual Convention 220 (1909) (observing that "[ $t$ ] he word 'ample' [as used in a rule requiring "ample margin"] may not have the same meaning in the minds of different people"); NHA, Report of the Twenty-Eighth Annual Convention 68 (1921) ("You will see at the end of each paragraph 'well baled.' That term is so indefinite .... There should be something more definite brought into it."); id ("I think the words 'good color' might be stricken out and insert something which the inspector or shipper or buyer will know what it means.").

${ }^{40}$ NHA, Report of the Sixteenth Annual Convention 229 (1909).

41 Id at 222-23. Only one participant spoke in favor of the reasonable time proposal, saying "[i]f it requires fifteen days in their market that is a reasonable time for them. If it can be done in three days in another place that is reasonable time in their market. I think anyone can readily form an opinion of what reasonable time is." Id at 223.

${ }^{42}$ UCC \$ 1-205 cmt 4. See also id at $\$ 1-205 \mathrm{cmt} 1$ ("This Act rejects both the lay dictionary' and the 'coveyancer's' reading of a commercial agreement. Instead the meaning of the agreement of the parties is to be determined by the language used by them and by their actions, read and interpreted in light of commercial practices and other surrounding circumstances.").

4 See, for example, Kreglinger \& Fernau $v$ Charles J. Webb Sons Co, 162 F Supp 695, 697 (E D Pa 1957) (noting that the "whole controversy centers around the single question, What did the parties intend when they inserted the word 'prompt' in the contract?" and looking to trade usage to define "prompt" but concluding that no usage existed because the plaintiff contended it meant "by the first available ship" and defendant that it meant thirty days), affd, 255 F2d 680 (3d Cir 1958). 
those terms meant. ${ }^{44}$ This lack of consensus led to many misunderstandings. The trade rules were conceived of as a way to avoid such misunderstandings by providing "a sort of dictionary to which all the members of this Association can go." ${ }^{\$ 45}$

The hay industry codification debates also suggest that some of the Code rules relating to the formation of contracts that rely on trade usage and commercial standards for their substance may be problematic. For example, the Code directs courts to look to "commercial standards on the point of "indefiniteness" 46 in determining whether an agreement is sufficiently definite to be enforced. However, hay arbitrators, like merchant arbitrators in many industries, ${ }^{47}$ routinely point out that contracts ought to be far more detailed than they are and frequently chastise parties for entering into unduly vague agreements. ${ }^{48}$

4 See NHA, Report of the Twelfth Annual Convention 155 (1905) (quoting a member as stating: "Suppose ... I should purchase of a shipper a carload of hay for prompt shipment. Technically that means nothing. It does mean something if I purchase a car of oats on the ... floor" of an official exchange with written trade rules) (emphasis added). Similarly, the Code defines a "commercial unit" in terms of "commercial usage," explicitly noting that it may be defined in terms of "a quantity [such as] a bale . . . or carload." UCC \& 2-105(6). However, in the hay industry there was no accepted meaning of either "bale" or "carload." In 1905, in a debate over whether trade rules should be adopted, one participant noted that "[i]t is a very grave question of doubt in any state what is meant by the shipment of ten cars." NHA, Report of the Twelfth Annual Convention 156 (1905). And, in 1910, the Arbitration Committee decided to "respectfully recommend that [the NHA] establish a rule to be added to our Trade Rules in which the number of tons of hay is specified that shall constitute a contract carload," NHA, Report of the Seventeenth Annual Convention 67 (1910), but the issue was not fully debated until 1921. NHA, Report of the Twenty-Eighth Annual Convention 85 (1921) (recounting the debate over the meaning of the term "carload," with some people saying it meant " 10 tons" and others asserting " 12 tons"). See note 69 and accompanying text.

${ }^{45}$ NHA, Report of the Twelfth Annual Convention 155 (1905).

4s UCC § 2-204 cmt.

${ }^{4}$ See, for example, Hinson v Parker Grain Co, NGFA Arbitration Case No 1628 (NGFA 1986) ("The arbitration panel was unanimous in wishing to caution the trade as to the necessity of using well-thought-out contracts that clearly encompass all of the obligations of both buyers and sellers to each other."); ASTA Yearbook 164 (1927) ("Counsel has rarely, if ever, seen a so-called business-man's contract which was not shy of some desirable provision.").

4 H.H. Driggs $v$ Walters Bros, in NHA, Report of the Eleventh Annual Convention 14546 (1905) ("[W]e find many of the terms of a contract of this kind ambiguous and indefinite."); NHA, Report of the Thirtieth Annual Convention 59, 61 (1923) (where the arbitration committee noted: "There is one suggestion I would like to leave with you and it is this-in making your sales and purchases pay more attention to trade rules No. 1 [setting out what a contract should specify] and No. 2 [dealing with sending confirmations]. *** Make definite contracts and observe your trade rules, and when this is done membership in The National Hay Association will be a real asset to your individual business"); NHA, Report of the Twenty-Ninth Annual Convention 108 (1922) ("We [the Arbitration Committee] are impressed that in most all cases trouble arises from the fact that contracts are carelessly made and too much is taken for granted by the contracting parties. It might be well to adopt a slogan, 'Take nothing for granted.' Both parties to a contract should file 
Despite these disagreements over the content of general usages and the meaning of common contractual language, a few general usages may have existed, ${ }^{49}$ and local pockets of customary practice were not uncommon. Many rule adoption and amendment debates, such as those relating to grading and inspection, took the form of debates among representatives of different regions and localities, ${ }^{50}$ each with their own practices. ${ }^{51}$ In some localities these customs took the form of unwritten practices, while in others they were codified in the rules of local hay associations or commodities exchanges.

More generally, much of the impetus for both codification and rule amendments came from members of the NHA's arbitra-

written confirmation, clearly defining all specifications and details governing said contract. All modifications should also be confirmed in writing and many cases for arbitration would be eliminated."); NHA Committee on Arbitration, Case 676, in NHA, Report of the Twenty-Eighth Annual Convention 140, 141 (1921) ("This controversy arises principally because plaintiff's confirmation in regard to time of shipment was indefinite, and further defendants also exercised gross carelessness in respect to confirmation in accordance with custom and trade rules."); NHA, Report of the Twenty-Fifth Annual Convention 131 (1918) (noting "the fact that 75\% of the cases which come before this [Arbitration] Committee would be avoided if contracts were made definite as to the time of shipment, grade, weights, and proper confirmations mailed by both parties"); NHA, Report of the Seventeenth Annual Convention 48 (1910) (where the arbitration committee attributed the rising number of cases to the use of "poor and faulty contract[s]" and recommended the adoption of an association-drafted "uniform explicit and binding contract for the use of its members").

40 For example, in most cash commodities industries, price adjustments were often given for slightly nonconforming tender. See, for example, T.B. Jones \& Co v Henderson Elevator Co (NGFA 1904), reprinted in NGFA, Decisions of the Arbitration and Appeals Committees of the Grain Dealers National Association 23-25 (1920) (In a dispute over rejection of an off grade delivery of corn, the arbitrators held that while "[c]ustom has held that where off grade grain is shipped, discounts may often permit contracts to be filled by applying such cars or quantities that are not equal to contract grade to be applied on contract at a difference. But there is no rule in the grain trade making it obligatory on the purchaser to accept such lower grades of grain.").

${ }^{\text {so }}$ While some of the practices so debated had distributional consequences, others such as how to define the quality associated with each grade designation-see, for example, NHA, Report of the Twenty-Seventh Annual Convention 74 (1920) (comparing grade rules of eleven sets of exchange rules)-related to routine matters where only coordination was important but transactors nonetheless fought for their preferred definitions. See id at 4650 (debating grade changes). Similar obstinance was exhibited in the grain industry. See 17 Who is Who in the Grain Trade 31, 33 (Jan 5, 1927-28) ("WWGT") (After noting that many local rules relating to shipping time contradicted the Grain Dealers National Rules, the chairman of the Trade Rules Committee stated that "in taking the matter up with the markets that differ we find on a whole that they are very conservative and tenacious in maintaining their rules but we are working on the question and gradually obtaining results.").

${ }^{s 1}$ See, for example, NHA, Report of the Fourth Annual Convention 24-25 (1897) ("[W]e are old fashioned folks at Boston, and this Association must not forget one thing, that what is applicable to one section of the country is not applicable to another."); NHA, Report of the Twenty-Eighth Annual Convention 68-72 (1921) (containing a debate over grades that emphasizes the existence of regional differences). 
tion committee who sought clearer guidance about how to decide cases. ${ }^{52}$ Although hay arbitrators took unwritten custom into account in filling gaps, they often did so with some reluctance and the industry itself had a strong preference for clear and brightline rules. ${ }^{53}$

\section{B. Grain and Feed}

The National Grain and Feed Association ("NGFA") formed in $1896^{55}$ and began arbitrating disputes shortly thereafter. ${ }^{56}$ It adopted the first Grain Trade Rules in 1902 and the first Feed Trade Rules in 1921. Achieving uniformity of rules and practices was an important goal of the rule adoption and amendment process. ${ }^{57}$

Prior to the national rules, the written trade rules of different local markets varied widely, ${ }^{58}$. and unwritten customs were

${ }^{82}$ NHA, Report of the Twelfh Annual Meeting 154 (1905) ("We wished to recommend the adoption of trade rules. We think it necessary for this Association to have trade rules printed. It would simplify the work of the Arbitration Committee and would make less work for that committee to do.").

${ }^{53}$ Id at 74 ("We should always keep in mind the benefits which associations like the Chicago Board of Trade and the New York Stock Exchange confer on their members, are due to their rigid rules, the basis of which is business integrity and mutual interest.").

st The NGFA, formerly the Grain Dealers National Association, is a trade association "for the North American grain and feed industry." Today, it has "more than 1,100 [member] companies ... that store, handle, merchandize and process more than two-thixds of all U.S. grains." David C. Barrett, Jr., Arbitrating Agricultural Disputes: The National Grain and Feed Association's Experience 1-2, reprinted in NGFA, NGFA Trading Seminar (no pagination in original) (cited in note 27). For a more detailed description of the industry's contemporary private legal system, see Bernstein, $144 \mathrm{U}$ Pa L Rev at 1771-87 (cited in note 13).

${ }^{s}$ Cross-country trade in grain was already common by the 1840s and accelerated quickly after the growth of railroads in 1898. William Cronon, Nature's Metropolis: Chicago and the Great West ch 3 (Norton 1991). Many grain traders were buyers one day and sellers the next, whereas in feed markets many transactions were between merchant sellers and end users.

st However, the first written arbitration opinion was not issued until 1902. Randall C. Gordon, A Century of Agricultural Abundance Through Free Enterprise: A Centennial Observance of the National Grain and Feed Association 53 (NGFA 1996). Prior to this time, numerous local associations had their own arbitration tribunals. Today, however, in the cash trade, only the Pacific Northwest Grain Exchange, the Los Angeles Grain Exchange, the Colorado Grain and Feed Association, and the Texas Grain and Feed Association continue to conduct their own arbitrations.

${ }^{\circ}$ President Clement Makes Committee Appointments, 10 WWGT 25 (Nov 20, 1920-21) ("After your committee has drafted trade rules and regulations which have been adopted by your Association, we recommend that your Association suggest to the various exchanges of this country that they in turn adopt these same rules and regulations so as to insure uniformity in transactions in mill feed.").

${ }^{\text {s }}$ Gordon, A Century of Agricultural Abundance at 49 (cited in note 56) (" $[W]$ hen the Grain Dealers National Association was founded ... each terminal market and grain exchange operated under its own set of trading rules and dispute-resolution procedures. Very little consistency existed between the trading rules of different markets."). In addi- 
nonuniform even within particular localities. ${ }^{59}$ As a grain dealer observed at the 1901 convention, many grain men "differ in opinion. Their ideas concerning what should and should not be done under certain conditions varies as much as the markets themselves." ${ }^{\prime 60}$ The divergence in opinion over the content of industry-wide trade practices was so wide that "a high probability existed that a dispute would arise whenever grain was traded outside local markets." ${ }^{61}$ More generally, as a transactor noted in an article published before the rules were drafted:

tion, the rules of local associations and exchanges were not regarded as necessarily establishing general trade customs. See, for example, Ewart Grain Co $v$ Wells-Abbott-Nieman Co (NFGA 1920), reprinted in NGFA, Decisions of the Arbitrators and Appeals Committees of the Grain Dealers National Association 316, 317 (1920) ("[T] changes, which permit second inspection and discount based thereon, are not an expression of general trade customs and are applicable only at markets which carry them in their rules."). The differences in the rules of local markets persisted even after the promulgation of the national rules, despite numerous efforts of the national association to promote uniformity. Effort to Unify Exchange Trade Rules Revived, 13 WWGT 27 (Dec 20, 1923-24). Some of these differences were attributed mostly to local dealers attempting to gain advantage. Are the Association's Trade Rules in Danger?, 13 WWGT 28, 29 (Feb 20, 1923-24) ("It is safe to say that in the local rules governing the different boards of trade there is unnecessary protection for the local members."). However, differences also existed over unifying practices with no distributional impact. See notes 50 and 74. Conflicts over whether a particular region's rules and customs should govern a particular transaction were not uncommon sources of disagreement between transactors in different localities. See, for example, Trade Rules: Chairman Replies, 13 WWGT 39, 41 (July 5, 1923-24) ("While it is true, as you state, that the general custom in your market is to buy on arrival drafts, it is also customary in the western markets to make all sales subject to demand drafts unless otherwise specified. Therefore, if the seller in this case was not familiar with the Richmond market and made the trade in good faith presuming that the Kansas City custom of demand drafts was understood, it might raise a question as to whether there was any contract at all as there would be no agreement or meeting of the minds on this term of the contract."). In addition, the differences in local rules, and the unwillingness of local markets, associations, and exchanges to change their practices even as to aspects of trade that had no clear distributional impact, were a frequent subject of trade press columns. See, for example, Trade Rules: The Chairman Replies, 17 WWGT 31, 33 (Jan 5, 1927-28) ("[U]niformity in the rules is a matter of slow growth as the different markets are very conservative in making changes in rules of years standing."). See also sources cited in note 50 .

${ }^{s s}$ See, for example, Minutes of Meetings: Secretary's Book (no page number) (Nov 9, 1896) ("Secretary's Book") (unpublished book of clippings; copies on file with author) (reporting that the Illinois Grain Dealers' Association created trade rules, to, among other things, "establish and maintain uniformity in commercial usages as far as the grain trade is concerned").

${ }^{\infty}$ Gordon, A Century of Agricultural Abundance at 51 (cited in note 56). See also The President's Address, in Secretary's Book at 117-18 (cited in note 59) (Peavy Address) ("Trade rules and custom will be an interesting subject and will help to enlighten us in regard to some of the ambiguous rules and customs now in vogue.").

${ }^{61}$ Gordon, $A$ Century of Agricultural Abundance at 49 (cited in note 56). In addition, as an early trade publication explained, "the farther the buyer is from the seller, the more the need of a careful and distinct understanding, for reasons well known." Secretary's Book at 111 (cited in note 59). Even today, in the Texas Feed Trade, transactors pay "much more attention to contract when you deal with those in other areas." Statement of Pre- 
As the situation now is, there are customs in the grain trade that are supposed to be established, but the trouble in respect to them is, they are not fixed, are not understood alike, some understand them in one way and others in another way, and for that reason, if for no other [they] cause difficulty. ${ }^{62}$

In response, in part, to this uncertainty, a Grain Trade Rules Committee was appointed. In 1901 it submitted fourteen recommendations relating to trade practices that it hoped would "do much to bring about a more uniform custom, eliminate friction and foster a better understanding and closer relations between the interior dealer at primary or intermediate markets." ${ }^{\text {"63 }}$ After submitting these recommendations, the committee sought additional time to draft a complete set of rules, explaining that the "wide area to be covered and the diverse interests to be equally represented" made its task difficult. It asked the state associations and local exchanges to "formulate their trade customs into a set of rules governing the transactions," so that the national committee would have a basis from which to work.

The first set of grain rules was quite detailed. However, some aspects of trade were not covered because customs differed significantly across the country and consensus could not be achieved. As one trade journal column noted:

I regret that it is not possible to give you a definite rule covering the case. The Grain and Feed Dealers National Association for two or three years endeavored to frame a rule which would cover a condition of this nature, but we found that the customs vary so largely in different sections of the country and so many technical questions arose that it was impossible to reach an agreement that would be national in scope. ${ }^{65}$

senter, TGFA Conference (1999).

- Secretary's Book (no page number) (cited in note 59).

* Gordon, A Century of Agricultural Abundance at 50 (cited in note 56). These recommendations dealt with confirmations, time for shipment, billing instructions, shipment, demurrage, sample sale, loading, terms, telegram, acceptances, surplus shipments, regular market terms, interior shipments, and invoices. Secretary's Book (cited in note 59).

* Gordon, A Century of Agricultural Abundance at 51 (cited in note 56).

* Chairman Replies, 20 WWGT 31 (Oct 5, 1930-31). See also Chairman Replies, 21 WWGT 28 (Dec 5, 1931-32) ("T T]he rules of the Grain and Feed Dealers National Association cover the broad principles of trading and details might differ as to the rate of interest, or the custom of charging to a certain date, in different sections of the country, so we have not attempted to formulate a rule on this point."); Hankerson Proposes Change in the Trade Rules, 14 WWGT 27 (July 5, 1927-28) ("[W]hile a rule [regarding diversion dates] has been suggested several times, none has been adopted, because it has been impossible 
When the first set of rules was finally introduced, merchants had many questions about how to interpret them. In response, the Association solicited "Ask the Chairman"66 letters from members and published detailed answers in the Association's trade journal. These columns reveal that an inability to agree on the content of custom was not only a reason for certain gaps in the trade rules, but was also a common cause of disagreement among transactors.

Even after the NGFA adopted Trade Rules, large variations in the written rules of local associations continued to exist. ${ }^{67}$ As the Chairman of the Trade Rules Committee explained in 1928, achieving "uniformity in the rules is a matter of slow growth as the different markets are very conservative in making changes in rules of years standing." 68

The grain trade press also confirms that prior to codification there was no agreement concerning the meaning of many basic contractual terms. For example, the meaning of the term "carload" led to numerous controversies ${ }^{69}$ and questions from industry members. ${ }^{70}$ Finally, it was suggested that grain should simply be sold by weight and the designation "carload" abandoned. ${ }^{71}$ Even-

to frame a rule that would meet all conditions or would state the general principle that would govern all transactions. It follows that each case would be settled on its merits with due consideration to customs of the trade in specific territory.").

"s These types of columns were common in the merchant trade press and typically contained many inquiries about the content of custom. See, for example, National-American Wholesale Lumber Association, Inc ("NAWLA"), Questions and Answers, North Coast Weekly Letter No 150 (Nov 25, 1924) ("What is the custom in making final settlements with mills when the wholesaler has purchased 'less $5 \%$ commission, underweights to mill to final destination?'); NAWLA, Questions and Answers, North Coast Weekly Letter No 140 (Sept 16, 1924) ("Question: 'A wholesaler has taken a cash discount on a Final Settlement sent to us four months after the date of shipment. Is he entitled to this discount and what is the custom in regard to this?"'; "Question: 'Where order is accepted for '85\% 10 ' and longer; balance shorter; usual lengths, well proportioned' what does 'well proportioned' mean according to present customs?"). See also note 143 (discussing the question and answer column in the silk industry journal, "The Silkworm").

${ }^{\text {}}$ Are the Association's Trade Rules in Danger?, 13 WWGT 28-29 (Feb 20, 1923-24) (extensively discussing differences in practices and rules from locality to locality).

* Trade Rules: The Chairman Replies, 17 WWGT 31, 33 (Jan 5, 1927-28).

- See, for example, Dispute Over Size of Cars: Smith Bros Grain Co v Security Mill and Feed Co, 10 WWGT 28-29 (Oct 5, 1920-21) (the "claim in this case arises over the question of the size of cars made applicable on a contract").

${ }^{30}$ See, for example, Replies of Chairman Watkins, 10 WWGT 38, 40 (Feb 20, 1920-21) (answering what is meant by the term "capacity" car); Replies of Chairman Watkins, 10 WWGT 42 (Feb 5, 1920-21) (addressing the question what is meant by the "contents of one 80 capacity car"); Replies of Chairman Watkins, 11 WWGT 43 (Dec 5, 1921-22) (answering the question "what constitutes a car load when a sale of grain is made without any reference being made as to the size of the cars").

${ }^{11}$ In a particular controversy there is reason to fabricate a dispute relating to the definition of a carload since the answer may have a key distributional impact. As one trade article noted, if the market "has declined . . . you are liable to find 60,000 capacity cars. 
tually a rule was adopted defining carload in terms of weight, but even after its adoption disputes continued to arise and the rule was amended several times. ${ }^{72}$ There was also no consensus as to the meaning of particular grades. ${ }^{73}$

Unlike the Grain Trade Rules, the Feed Trade Rules did not take long to draft once the codification effort began. However, the need "for uniform rules" had been obvious for years. Prior to adoption of the rules, trade practices varied widely: "The feed men [ ] never had uniform rules to govern their transactions ... there were many sets of rules in different localities but there was no uniformity." Although "sporadic efforts were made from time to time to achieve this most desirable object, ${ }^{m 5}$ consensus could not be achieved and the efforts to adopt written trade rules had always failed. Finally, due to the efforts of a strong-willed man, a Feed Trade Rules Committee was appointed. It met in intense session for two days and came up with a draft set of rules. In reporting the work of his committee to the association as a whole, the committee chairman did not attempt to give the rules legitimacy by claiming that they codified custom. Rather, he explicitly acknowledged that they were the result of compromise, noting that "[w]e succeeded in formulating rules that all of us agreed upon as being the most equitable rules that it was possible to draw up. We were in session two full days. Every point was threshed out."76 The fact that the feed rules were not based strictly on custom, and that they were similar in many respects to

Should the market advance the cars furnished will be 30,000 capacity." Secretary's Book at 50 (cited in note 59).

${ }^{72}$ See Trade Rules of the Grain Dealers National Association (1920), reprinted in 10 WWGT 39-40 (Nov 20, 1920-21) ("A carload shall consist of bushels as follows: Wheat 1,100; shelled corn, milo maize, kaffir corn, and feterita, 1,100; ear corn 700 . . . Provided, that where the rules of carriers lawfully on file with the Interstate Commerce Commission or State Railway Commission provide for minimum carload weights in excess of the above, such minimum weights shall constitute a carload within the meaning of this rule."); Trade Rules, 17 WWGT 33-34 (Jan 5, 1927-28) (discussing a letter on the meaning of carloads). See also Trade Rules Changes, 13 WWGT 38 (Oct 5, 1923-24) (discussing the amended Rule 32 dealing with the definition of carloads).

${ }^{73}$ See, for example, Secretary's Book at 54 (cited in note 59) ("[T]he grading of the different cereals in our markets in the United States vary so widely that it is almost impossible to tell by the inspection at one market on any kind of grain, what the same class of grain will grade in some of the other markets."); id at 63 ("We should discuss plans and adopt measures which would lead to uniform grading.").

7 Trade Rules to Govern Transactions in Feedstuffs, 10 WWGT 25 (Apr 5, 1920-21). When the feed rules committee was first appointed, it was directed to make "inquiry from the various markets and for the sake of uniformity define what should constitute "prompt, quick, and immediate shipment." President Clement Makes Committee Appointment, 10 WWGT 25 (Nov 20, 1920-21).

7s Trade Rules to Govern Transactions in Feedstuffs, 10 WWGT 25 (Apr 5, 1920-21).

${ }^{76}$ Id (statement of E.C. Dreyer, Chairman of the Feed Committee). 
the grain rules, might account, in part, for the relatively short amount of time it took to draft them.

Although the NGFA Rules Committee has met annually since 1902 "to review the rules ... [in an effort] to ensure that the Trade Rules reflect-but do not set-industry trade practices, ${ }^{m 7}$ most rule changes have in fact been attempts to clarify vagueness, ${ }^{78}$ respond to technological changes, ${ }^{79}$ change customs ${ }^{80}$ or to simply adopt more desirable practices. ${ }^{81}$ Today, the Trade Rules Committee is comfortable adopting and amending rules based solely on their desirability and likely effect. ${ }^{82}$

\section{Textile Industry}

The debates surrounding the 1936 adoption of the Worth Street Rules ("WSR"), ${ }^{83}$ which in modified form continue to govern

"Gordon, A Century of Agricultural Abundance at 52 (cited in note 56). Since their inception, the Grain Trade Rules have been amended fifty-eight times and the Feed Trade Rules thirty-two times. Id.

${ }^{78}$ For example, the rules defining "business day/holiday" became more specific over time.

73 See Trade Rules and Arbitration Rules, 14 Grain Trade Rules R 45 ("Electronic Data Interchange") (1995) (making the trade rules applicable to "trades that include electronic transmission and receipt of data in agreed formats in substitution for conventional paperbased documents").

so See, for example, Grain Trade Rules Rule 29 (1922), reprinted in 12 WWGT 37 (Nov $20,1921-22$ ) ("The specifications of a contract cannot be altered or amended without the expressed consent of both the buyer and the seller. This abolishes the custom of 'silence confirms." ). See also Hankerson Proposes a Change, 17 WWGT 27-28 (July 5, 1927-28) ("W]e [the Trade Rules Committee] would like to get the reaction of the trade as to the advisability of incorporating in the rules of the Association a rule which would be at variance with other customs in different parts of the country.").

" See, for example, Proposed Changes in Association's Trade Rules, 11 WWGT 23 (Sept 20, 1921-22) (proposing "add[ing] to the present rule" a provision that "[a]ny loss resulting from irregular or incorrect invoices shall be paid for by the seller," and justifying it on the grounds that "[t]he idea of the proposer of this change is that the invoice shall be given more nearly the same dignity as the Bill of Lading to prevent losses due to careless invoicing"); NGFA, Trade Rules and Contracts 7 (pamphlet, no date) ("The general objectives of the Trade Rules Committee are ... [among other things] to formulate and recommend to the membership, trading rules that will bring about improvement of marketing procedures in the industry . . . and enact new rules as needed to impartially govern transactions.").

22 This conclusion is based on my attendance at a meeting of the Committee (Washington, DC 1995).

These rules were jointly adopted by the Textile Fabrics Association, Cotton-Textile Institute, Fine Goods Committee of the Cotton-Textile Institute, International Association of Garment Manufacturers, Union-Made Garment Manufacturers' Association, American Cotton Manufacturers Association, National Association of Cotton Manufacturers, New Bedford Cotton Manufacturers Association, Wholesale Dry Goods Institute, National Association of Purchasing Agents, Textile Brokers' Association, and Association of Cotton Textile Merchants of New York. WSR 2 (1936). Before and during the rules creation process, the textile industry was geographically concentrated "[i]n a compact area of some six blocks, located just north of City Hall Square in lower Manhattan," which contained the 
most textile transactions today, ${ }^{84}$ together with other evidence about the textile trade, suggest that that prior to codification, both trade practices and the industry meaning of particular terms varied widely. ${ }^{85}$

The idea of codifying textile industry customs, in an effort to "improve trade practices," was first raised at a 1918 meeting at the Union League Club, where the idea "of devising a uniform sales contract to simplify all market transactions" received strong industry support. ${ }^{87}$ Shortly thereafter, the Association of Cotton Textile Merchants of New York ("ACTM") was formed, and it made the adoption of trade rules a high priority, explaining that:

[C]ontracts, to be sacred, must be sound. They must be based upon fairness to buyer and seller alike; and this implies acceptance on all sides of standards of fair trade practice. Such standards usually evolve from practical conditions as customs or unwritten laws, and men have tried perennially to write them down, to codify them, so that disagreement and

\footnotetext{
"market for virtually all of the nation's output of cotton cloth." The Association of Cotton Textile Merchants of New York, 25 Years 1 (Parker-Allston 1944) ("Textile History"). Although industry members were drawn from many walks of life all over the country, they developed a close-knit culture of their own. "[T] $]$ he first Worth Streeters were incureably addicted to the stovepipe hat and frock coat, which continued to be the symbol of their calling, and virtually their uniform, until the presidency of the first Roosevelt." The Worth Street Story, 22 Am Fabrics 47, 48 (1952). Most merchants ate lunch at one of three eating clubs, and the social ties they formed were so strong that most transactions were repeat and "[e]very year millions of dollars worth of goods were sold without a paper that could be taken to court in the case of a dispute. This unique and really wonderful method of handling even the largest transactions still represents the philosophy behind the Worth Street way of doing business." Id at 48-49.

st Jean E. Palmieri, Lawyers Group Publishes Revision of Worth Street Textile Market Rules, 16 Daily News Rec 9 (Nov 12, 1986) ("The rules [WSRs] are commonly recognized as the standard code of procedure and trade customs for the purchase, sale and use of textiles and allied products."). The WSRs were revised in 1941, 1947, 1964, 1971, and 1986. The 1986 revision was undertaken by a group of textile lawyers whose goal was to simplify the rules and make them more accessible. Id. The rules are incorporated into most textile contracts, which also provide for arbitration under the Rules of the General Arbitration Council of the Textile and Allied Trades, which are today administered by the American Arbitration Association.

* See Note, Enforceable Arbitration of Commercial Disputes in the Textile Industries, 61 Yale L J 686, 711 n 147 (1952) ("Before the rules [WSRs], major disagreement was over the inclusion of second quality cloth in each shipment, grace periods after delivery, and the meaning of trade terms. In rayon, where there is virtually no agreement, conflict on the meaning of trade custom is rife. .. . [In addition,] the definitions of imperfections reflect the manufacturer's interest that 'normal irregularities natural to the fibers used' exist and that ' $a$ reasonable number of manufacturing defects must be expected.' The standards leave 'normal irregularities' undefined. . . . There is basic disagreement on what non-conformity is.").

Textile History at 37-38 (cited in note 83).

"Id at 13-14.
} 
misunderstanding might be reduced to a reasonable minimum. ${ }^{88}$

The process of drafting the WSRs was fraught with conflict, involved negotiations among numerous trade associations, and proceeded slowly. The effort to draft a uniform sales note, which was to become a key section of the WSRs, began in 1910. In 1920, six proposed standard notes were recommended to ACTM members, but as late as 1932 uniformity of practice had not been achieved. ${ }^{89}$ In 1932, after two years of committee work devoted solely to that subject, a standard set of eight Salesnote Clauses was finally published. ${ }^{90}$ In 1934 the first standard Cotton Textile Salesnote was introduced. It was subsequently incorporated into the 1936 WSRs after an additional year of committee work. ${ }^{91}$

Work on other aspects of the rules, such as the compilations of usages in different branches of the trade, proceeded similarly slowly. In 1928, for example, a committee was appointed "to begin negotiations with representatives of the converters for the purpose of defining some customs prevailing in the purchase and sale of grey goods, ${ }^{m 22}$ an effort that was not completed until 1931.

The 1936 WSRs, a culmination of eighteen years of concerted effort on the part of industry participants, were an extraordinarily detailed set of contract default rules. They covered many stages of the manufacture and distribution of a variety of textile products and defined numerous quality specifications, trade terms, and trade customs for transactions in different types of goods. ${ }^{93}$ Nevertheless, even after their adoption, substantial disa-

${ }^{23}$ Id at $37-38$.

Id at $40-41$.

${ }^{9}$ Id at 40. See also Uniform Salesnote Clauses Recommended to Cotton Textile Trade, Textile World 33 (Apr 6, 1932) (reprinting the Uniform Salesnote Clauses and a brief statement in their support).

"1 Textile History at $41-42$ (cited in note 83 ).

${ }^{2}$ Id at 39.

${ }^{93}$ The 1936 WSRs were thirty-nine pages long. They included a Standard Cotton Textile Salesnote, codifying customs and definitions dealing with allowances for deficiency, arbitration, "as are," cancellation, rejections and claims, deliveries, general strike or lockout and normal production, goods not sold by description, latent defect, methods of testing materials in dispute, packing, patent defect, quantities run of the loom or mill, seconds, selection of representative pieces, selvage count, standard seconds and tailing clauses, storage and insurance, strike or casualty, tailings, tape selvage and feeler motions, tensile strength, and use-as well as special customs relating to the converting trade and what is termed "pertinent data concerning the bag trade." WSR "Table of Contents" (1936). The 1941 and 1947 WSRs were seventy-one pages long. By 1964, the WSRs had expanded to one hundred twenty-eight pages, and even after the 1986 revision, which was aimed at simplification of the rules, they were still fifty-eight pages. Despite the extraordinary detail of the WSRs, traders did not view them as providing the terms of a near complete contingent-state contract. See Note, 61 Yale $I J$ at $701 \mathrm{n} 88$ (cited in note 85) ("[I]t is quite 
greement over the trade meaning of even words that were themselves defined in the Rules persisted. For example, although the 1936 WSRs included definitions of the widely used designations "first quality" and "seconds," precisely the types of terms the Code directs courts to look to usage to define, ${ }^{95}$ a 1949 National Federation of Textiles Report on Association Activities contains a discussion of attempts to compile "A Dictionary of Trade Expressions":

What is meant by a piece of goods'? What does r.o.m. mean? What is a 'second'? Does 'as are' include remnants? These were questions asked so repeatedly during 1949 , that at the close of the year, plans were under way, to compile an official list of trade expressions of this type. ${ }^{96}$

Similarly, a 1952 academic study of textile arbitration found substantial disagreement among transactors as to the meaning of these and other terms,${ }^{97}$ concluding that in the industry as a

evident from interviews and questionnaires that the Worth Street Rules have many loopholes. . . . Many of the existing definitions are inadequate. For example, definitions of first quality or run of the mill depend on a specific mill's records. These two terms are extremely variable. . . . Merchants also point to the failure of the rules to cover many issues raised in disputes. ... Specifically, textile men report that the rules overlook finished goods and finishing qualities. . . . Correcting these deficiencies, however, is extremely difficult because textile disputes present an infinite number of variables.").

" Definitions and Trade Customs, WSR 32 (1936) ("The word 'Seconds' is applied to cloth inferior to that which the subject mill grades as 'Standard' or 'first quality.' . . . Unfortunately, the grading of cloth does not lend itself to specific definition. Practice varies with different mills and for different uses.").

* See, for example, Foxco Industries, Ltd v Fabric World, Inc, 595 F2d 976, 984-85 (5th Cir 1979) (holding that in determining the meaning of "first quality" it is proper to look to trade usages, since parties are "presumed to have intended the incorporation of trade usage in striking their bargain").

sational Federation of Textiles, Inc, The National Federation of Textiles Reviews . . . Activities. Officers. Members 71, 72 (1948, 1949, 1950). See also National Federation of Textiles, Annual Report of National Federation of Textiles, Inc, 75th Annual Report 19 (1947) ("Coincident with suggestions for revision of the recommended contract [for rayon] came repeated questions from buyers of grey goods as to the meaning of such phrases as 'run of the mill,' 'as are,' 'seconds,' etc. The cotton market had incorporated definitions of such terms in their Worth Street Rules, but nothing comparable had been prepared for rayon fabrics, despite the apparent general use of similar terms in that branch of the industry. It was thought this might be a subject of future determination through the Federation.").

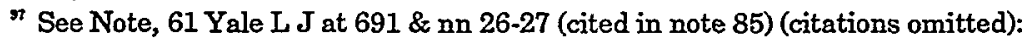

Trade practice in classifying goods as first or second quality may facilitate buyer's efforts to escape. These terms are not absolute; they are based on the particular plant's past performance, a vague and shifting standard at best. *** The difference between first and second quality is not clear. By definition second quality goods are merchantable and reasonably free from major defects; yet they are inferior to and contain more imperfections than first quality goods. The definition says no more. *** In cottons the standard [for first and second quality] not only varies from plant to plant but also 
whole, "trade custom . . . is often amorphous and unsettled."98 Indeed, the study found that lack of consensus on the meaning of customs was one of the main reasons that transactors strongly preferred three arbitrator panels to single arbitrator adjudication in which the single arbitrator's idiosyncratic view of trade custom would most likely be applied. ${ }^{99}$

Finally, the WSRs themselves posed a challenge to the Code drafters' decision to accord written usages (in the form of trade codes) and unwritten usages the same weight in adjudication. The Forwards to various editions of the WSRs reveal that textile merchants conceived of a hierarchy of trade customs. As the 1936 WSR Forward stated, contingencies not covered by the standard salesnote "shall be interpreted in accordance with the established rules and customs of the trade, particularly with those rules and customs which have been formally approved by authorized bodies, representing both buyer and seller."100 The WSRs themselves separately listed customs that applied to the trade as a whole and those that applied only to particular subdivisions. Moreover, the 1936 Forward cautioned that constant vigilance was needed to ensure that rules and customs were reviewed periodically so that "those [customs] that are determined to be entitled to recognition," could be "list[ed] in proper form."

from fabric to fabric. . . Rayon finished goods are classified on an industry-wide standard. . . . But rayon merchants assert that the standard is just as vague as that used for cottons.

${ }^{98}$ Id at 700.

${ }^{93}$ Id at $712 \mathrm{n} 152$ ("Some converters state that the possibility of trade bias is so great in the absence of agreement on trade custom that they will not go to arbitration."); id at 711 n 149 ("Many merchants stated expressly that one man [the arbitrator] might incorporate his trade bias in the fact-finding process."); id at $710 \mathrm{n} 142$ ("Textile men prefer three man to one man arbitration" in part because it results in "a less arbitrary approach to the issues," and "more expert knowledge [being] brought to bear on the case."); id at $698-99$ \& $n 69$ (noting the merchant's preferences for a three arbitrator structure); id at 711-12 (discussing how an arbitrator's status in the trade might affect his view of trade custom).

${ }^{100}$ Forward, WSR 1 (1936). Although the quoted material seems to give unwritten custom some legitimacy, the Forward subsequently discusses the proper sources of authority for arbitral decisionmaking, noting that "the Salesnote and Specifications nearly always are considered together, but not everyone realizes ... that Trade Customs [as defined in these rules] are the interpretations of them which should govern sellers and buyers in their trading and which in turn, should guide arbitrators in their decisions." Id. The rules give the Salesnote precedence over even written custom. WSR 23 (1960) ("In the case of conflict, express or implied, between the Salesnote and the section on Definitions and Trade Customs, the Salesnote governs."). Later WSRs forbid the arbitrators from looking to anything other than the contract and written custom. Moreover, even when merchants agree that something is indeed a customary practice, absent a contract clause requiring that the practice be followed, they do not necessarily infer from the fact that something is done that it should be done. See note 138.

${ }^{101}$ Forward, WSR 1 (1936). 
themselves came to be recognized as custom ${ }^{102}$ and the rules themselves came to discourage recourse to unwritten custom. The Standard Salesnote in the 1986 WSRs introduced a term providing that arbitrators "shall have no power to alter or in rendering their award to depart from any express provision of this contract, and their failure to observe this limitation shall constitute grounds for vacating their award." 103

More generally, the existence of comprehensive codified customs was considered an essential reason for the success of textile arbitration. As the 1952 study noted, "Lack of mutually acceptable codes of trade custom in rayon has in large part been responsible for any dislike of rayon arbitration. Agreement on codified trade custom in cotton, on the other hand, has been a major factor in the success of its arbitration." ${ }^{104}$ And, as a 1919 editorial in Textile World Journal noted, "in the past, sellers, as well as buyers ... have viewed with suspicion such [an arbitration] plan for settling disputes. They have felt that competitors in their line of business might not be in a position to give an unbiased decision on matters involving usage in the trade with which they are connected." 105

\section{Silk}

The Silk Association of America ("SAA") 106 had one of the earliest and most well-regarded arbitration systems. ${ }^{107}$ Like the

\footnotetext{
${ }^{102}$ See WSR 3 (1941) ("By common consent and almost universal usage, [the WSRs] have come to be recognized as the standard code of procedure and trade custom applicable to the purchase and sale of cotton textiles and allied lines.").

${ }^{100}$ WSR 3 (1986).

${ }^{101}$ Note, 61 Yale $L J$ at 713 (cited in note 85).

${ }^{1 \infty}$ Advantages of Arbitration, Textile World J 30 (May 17, 1919). See also Legal Cancellations, Textile World J 38 (Dec 18, 1920) ("At various times when the subject of a standard sales note has been considered, the need of such standards and tolerances has been recognized, but with very few exceptions, none have been developed that could not be punched full of holes by clever lawyers. The usual procedure when a case of this kind comes before the court is for both the plaintiff and defendant to call as witnesses a number of so-called authorities to testify regarding trade custom.").

${ }^{100}$ See American Arbitration Association, Year Book on Commercial Arbitration in the United States, 1927772 (Oxford 1927) ("The Silk Association of America, Inc., is a national organization, established 'to promote the advancement and prosperity of the silk interests.' [Its members include] raw silk importers, dealers and brokers, commission throwsters, manufacturers of swing silks and twists, broad silks, ribbons and hatbands, laces, nets and veilings, knit goods and glove silks; skein dyers, piece dyers; printers and finishers; manufacturers of silk machinery and supplies; manufacturers' agents and commission merchants.").

${ }^{107}$ Irving S. Paul, J.W. Millard, and James S. Taylor, Trade Association Activities 112 (Department of Commerce 1927) (describing and lauding the operation of the SAA arbitration tribunal); I.L. Blunt, American Commercial Arbitration, 3 Arbitration J 299 (1939) (describing the SAA as an arbitration "pioneer").
} 
textile system, it governed transactions among merchants who played fixed roles in the chain of production and distribution of sill. The arbitration system was created in $1898,{ }^{108}$ but trade rules were not adopted until several years later. The SAA ByLaws noted that the Association aimed, among other things, to "establish and maintain uniformity and certainty in the customs and commercial usages of the silk trade," ${ }^{109}$ and early reports noted that "committees of the Association are intelligently and constantly ... seeking to improve trade usages, and to substitute better methods as between buyers and sellers."110

The rules creation process at the SAA was even more contentious and drawn out than in other associations. ${ }^{111}$ For example, work on the Trade Rules for Raw Silk began in $1901,{ }^{112}$ but after "two years of fruitless discussion of the rules proposed, the committee was discharged at the request of its own chairman." ${ }^{113}$ As an Association report explained, "The get-together spirit was not sufficiently pronounced to override the differences that arose when the rules in detail were considered."114 Work on the rules resumed in 1907, and new rules were adopted in 1908, after fourteen separate committee meetings, "several conferences between the Raw Silk Division . . . and the Board of Managers"115 to address "difficulties," and the "approval of some amendments." approving the rules, the Board of Managers emphasized, as did the preambles to the rules themselves, that they were merely default rules. ${ }^{117}$

${ }^{108}$ Blunt, 3 Arbitration $\mathrm{J}$ at 300 (cited in note 107). The SAA also sponsored an Examination Bureau to make quality determinations and an Adjustment Bureau that offered informal mediation services.

${ }^{109}$ By-Laws of the SAA Art II, § 1, in SAA, Forty-First Annual Report 12 (1913).

${ }^{110}$ SAA, Thirty-First Annual Report 28 (1903).

"II One reason for the unusual level of tension may have been that buyers associations negotiated with sellers associations so that the distributive impact of the outcomes reached might, along many dimensions, have been quite serious.

${ }^{112}$ Efficient Distribution an Aid to Industry, 6 Silkworm 365, 367 (Feb 1925).

${ }^{13}$ SAA, Thirty-Fifth Annual Report 23 (1907).

"it'Id.

${ }^{115}$ SAA, Thirty-Sixth Annual Report 35-36 (1908).

${ }^{115}$ Id at 36. These Rules were amended in 1912, SAA, Fortieth Annual Report 31 (1912), in 1921 after "a year of careful study on the part of the committee," Revision, 3 Silkworm 73 (May 1921), and again in 1924 after the "culmination of many months of intensive effort on the part of a committee of representative buyers and sellers to revise the rules in such a way as to cover changes in trade customs which had developed since . . . 1921," including changes in credit terms and "provisions for claim, rejections and replacements which were rephrased so as to conform with customs which had developed in the trade and to cover those points which had not, perhaps, been clearly understood." SAA, Fifty-Third Annual Report 26 (1925).

"SAA, Thirty-Sixth Annual Report 83 (1908); Raw Silk Rules and Regulations, in id at 77 (" $[N]$ othing in the following rules shall be construed as waiving the right in individ- 
The creation of the Silk Throwsters Rules ${ }^{118}$ in 1907 after a year of "active group work" ${ }^{119}$ was also contentious, ${ }^{120}$ but proceeded relatively quickly, perhaps because the group adopted "practically the same rules which obtain in Europe."121 The goal of the codification movement was to get "business conditions on a more uniform basis and [formulate] a standard set of trade rules, which would be acceptable to both manufacturer and throwster." 122

The creation of Rules for Thrown Silk was also a controversial process. After several years of committee work, the first draft of the rules was proposed in 1923, but rejected by the Association. This raised the ire of their author, who stormed:

The Thrown Silk Division of the Association has been at work with a committee appointed by the Association for a number of months past on rules to regulate the sale of thrown silk in all its branches, and after a great deal of time and labor, their recommendations were submitted to the Board of Managers of the Association. These recommendations were based on current market practice, and it is to be regretted that the Board did not see fit to accept them as

ual transactions to make any special or distinct contrary agreement, but that the rules shall govern only in cases where no special or specific contract exists.").

"These rules were quite detailed. They defined acceptable tolerances, manufacturing techniques, various allocations of liability, payment, and transport. They also noted that "the amount of loss to be allowed in the actual working of a given silk (to be arrived at as above stated) is universally a matter of agreement between the manufacturer and the throwster." Id at 32.

${ }^{110}$ Trade Practices, 2 Silkworm 28 (Feb 1921).

${ }^{120}$ The creation of other sets of rules was somewhat less contentious. The Rules Governing Broad Silks, "which embody the best sentiments of prominent manufactures in this leading branch of the industry," were drafted in 1912-13. SAA, Forty-First Annual Report 45 (1913). The effort to adopt them, however, began in 1907 and "was continued intermittently for a number of years until, by virtue of the most dogged efforts and persistency, a set of trade practices was adopted and approved." Trade Practices, 2 Silkworm 28 (Feb 1921). The Rules Governing Spun Silk were drafted during $1921-22$ and adopted in 1923 with little fanfare. SAA, Fifty-First Annual Report 56 (1923). They were amended in 1928 in a process described as "translating customary trade practice into uniform trade rules." SAA, Fifty-Sixth Annual Report 16 (1928). In addition, "Rules Governing the Commission Throwing of Silk" were adopted in 1927 as part of a renewed attempt to achieve "advancement in the standardization of trade practices through the adoption of rules and forms." SAA, 55th Annual Report 17 (1927). During 1927, a wide variety of standard form contracts were adopted. SAA, Fifty-Sixth Annual Report 17-25 (1928).

${ }^{121}$ SAA, Thirty-Sixth Annual Report 53 (1908).

${ }^{122}$ SAA, Thirty-Fifth Annual Report 55 (1907). See also SAA, Thirty-Sixth Annual Report 30 (1908) (amending the Throwsters Rules to include a "standard weight" provision to eliminate "the former uncertainty and divergence in the kind of weight charged for by throwsters"). 
submitted, and thus place an important branch of the silk industry on a sound economic basis. ${ }^{123}$

The rules were eventually adopted in 1924, "the result of four years' endeavor to compile the list of best trade practices . . . based on suggestions and experiences from both buyers and sellers," the Association also began to promulgate standard form contracts in an effort to bring about even greater uniformity in trading terms. The various rules adopted by the SAA were amended numerous times during the 1920s and 1930s, ostensibly to respond to changes in trade practices. ${ }^{126}$

The contentiousness surrounding the adoption of silk trade rules is in some respects surprising. There was much more agreement about the content of existing practices than in other industries, perhaps because of the somewhat smaller number of individuals engaged in the trade. However, unlike merchants in many industries who often venerated existing practices, silk transactors frequently criticized existing practices as being out of date, inefficient, or just plain stupid. ${ }^{127}$ Like the grain dealers,

${ }^{123}$ SAA, Fifty-First Annual Report 55 (1923).

${ }^{124}$ SAA, Fifty-Second Annual Report 23 (1924).

${ }^{125}$ Id.

${ }^{128}$ See notes 120 and 122; SAA, 57th Annual Report 22 (1929) ("Both revisions of finished goods rules and compilation of raw goods rules have been based on market practices and customs, generally accepted in the silk industry."). Some of the changes introduced in the 1930s might have been responses to the National Industrial Recovery Act of $1933 \mathrm{ch}$ 90, 48 Stat 195 (1933), codified at 15 USC $\S \S 701-12$ (1994), terminated by Exec Order No 7252 (Dec 21, 1935), and government initiatives related to it, which among other things, encouraged trade associations to adopt rules known as codes of fair competition. See generally Allen R. Kamp, Between-the-Wars Social Thought: Karl Llewellyn, Legal Realism and the Uniform Commercial Code in Context, 59 Albany L Rev 325, 370 (1995) (discussing the influence of the NIRA on trade association activities).

${ }^{127}$ SAA, Thirty-Fifth Annual Report 57 (1907) ("[W]hy this stupid custom [of 'another bill and the old price'] should continue, no satisfactory explanation can be given. There is no more reason for this, than for the equally foolish custom that prevailed for many years in giving the jobber 'protection in case of a decline in price."); SAA, XLIII Annual Report 41 (1915) (noting that tie silk manufacturers would be better off if it were "possible to induce the trade to break away from their fixed traditions") (emphasis added). See also SAA, Third Annual Report 64-65 (1875) ("It is strange how far custom will lead us, when our better judgment would not go a step. This may be especially the case, in regard to the custom of charging single ounces on a bale of silk. Not a merchant, not a manufacturer, not a throwster, but knows that silk is very sensitive of atmospheric changes, that bale will vary by weight a few ounces if weighted twice in one day, and yet they all sanction this custom by tacitly conforming to it without objection."); Ribbons Report, in SAA, Forty-Fourth Annual Report 65 (1916) (harshly condemning the practice of the "the open order, with no definite date of assortment," attributing the practice to "the custom of the trade, as constituted at present [which] did not compel [buyers] to assort the goods until they were needed, which might be at any future time, if at all"); SAA, XXXXI Annual Report 38 (1903) ("It has often been noted that it is the custom with most manufacturers to continue their 
they lamented the difficulty of changing existing practices. As one SAA banquet speaker put it, "Huge question marks are boldly scribed on the walls of custom, hoary with age, and covered with the ivy of reverence and toleration.." ${ }^{\prime 28}$ Similarly, as the 1918 Annual Report noted:

Modifications of trade customs are exceedingly difficult to introduce. Trade practices are handed on from generation to generation of office administrators and when a business routine is established in an organization it often requires a reorganization, a so-called 'shake-up,' to introduce innovations. Considering this conservatism the [success of the SAA in modifying practices] may be looked upon justly as a real accomplishment of the Association. ${ }^{129}$

The hostility toward custom in this industry might have been due, at least in part, to the fact that many customs were perceived to be, and might well have been, "customs of adhesion," or attempts of particular branches of the industry to secure competitive advantage.

Although customs in the silk industry were better established than customs in other industries, there was still much disagreement about the meaning of basic trade terms. For example, at the 1915 SAA Convention, one speaker pointed out that there was no common understanding of the term "Double Extra" silk:

There is not a man here who could give a definition. Some of you men, however, can tell us what No. I Buckwheat coal is, and for the simple reason you have a standard to go by, and certain tests that No. I Buckwheat must live up to. When we have a standard for Double Extra silk, and certain tests that a Double Extra must meet, then will you be able to define a Double Extra. The present Double Extra silk is any one man's opinion. ${ }^{130}$

output for the Fall consumption on the same basis as the Spring, when it is known, without contradiction, that the demand for the last part of the year is much less than for the first half.").

${ }^{125}$ SAA, XLII Annual Report 145 (1914). See also SAA, Thirty-Sixth Annual Report 21 22 (1908) ("The silk interests have come to one absolute conclusion, and that is that all past methods that have not proven sound and reliable need to be revised.").

SAA, 46th Annual Report 82 (1918). See also SAA, Forty-Fourth Annual Report 5758 (1916) (where the Tie Silk Association boasted that progress had been made in achieving change in the face of powerful customs, noting that "[w] hat had been hitherto considered impossible for the neckware trade, that is to pay more than 80 to $821 / 2$ cents for their 50 cent line, was accomplished. Old traditions were brushed aside").

${ }^{130}$ Proceedings of the First National Silk Convention 136 (1915) ("First Silk Conven- 
In addition, numerous other practices, particularly those relating to grade designations, were quite varied in different geographic areas. ${ }^{131}$

\section{E. Methodological Problems}

A serious difficulty raised by drawing on the trade association codification debates to explore whether industry-wide, unwritten customs existed is that the data is also consistent with the possibility that industry-wide customs did exist, but that the codification debates provided an opportunity for rent-seeking subgroups to fabricate disputes about the content of custom $^{132}$ and

$t^{\prime \prime} n^{\text {). }}$ More notably, in 1923 a Committee of the British Silk Association wrote a report attempting to define the word silk. See Proper Use of the Word "Silk" Defined by Committee of British Association, 5 Silkworm 176 (July 1923) ("Silk means the natural product of the silkworm, whether Net Silk or Spun Silk" and should not, with the exception of "[c]ertain smallwares containing Silk in combination with other fibres ... [that] have been by long established custom known as Silks," be "used for combined fabric products.").

${ }^{131}$ See, for example, First Silk Convention at 119 (cited in note 130) ("There exists in raw silks a Japan, Italian, China, French, Turkish and Canton classifications, which are all unlike. ... Taking everything into consideration, the six classifications have no resemblance to each other at all."); James Chittick, Silk Manufacturing and its Problems 25 (James Chittick 1913) ("Yokohama classifications do not correspond with those of New York, the No. 1 of Japan being called here Best No. 1."). Moreover, the way quality designations were defined tended to change from year to year as crop conditions changed. See, for example, First Silk Convention at 119 (attributing the "fluctuation of classifications" to the fact that "after a rainy season, when all the qualities of silk are poorer, the same classifications are retained so that an Extra in 1915 is different quality from an Extra in $1914^{\prime \prime}$ ). This type of variation would create significant problems for a court applying the Code because cases typically go to trial several years after a dispute arises, so reconstructing the content of time-dependent industry customs of this type would be quite diffcult.

${ }^{152}$ Conversely, statements that custom exists must also be interpreted cautiously. The Report of the 1909 convention of the NHA, for example, contains a discussion in which one transactor asserted the existence of a custom relating to a shipment term and another member nonetheless suggested that they "write it out." NHA, Report of the Sixteenth Annual Convention 216 (1909). As they attempted to formulate a rule on the matter they tried to answer a series of hypotheticals until it became clear that the proponent of the custom could not defend it as providing the relevant answers. Id at 216-17. Similarly, at the 1999 Texas Grain and Feed Association conference, a speaker on the arbitration process noted, "it turns out [with respect to customs of the trade that] people who think they agreed have very different ideas when it is applied to specific cases."

It is also possible that, to the extent that participants in the codification debates received prestige or improved business contacts from actively participating in the committees of the national trade association in their industry, they may have had an incentive to exaggerate the lack of uniformity in trade practices in order to enhance the perceived importance of the association and its codification efforts. Although this explanation might account for some of the statements made by high-ranking association founders in the early years, it is unlikely to be a complete explanation. The codification of trade rules was considered an important association function. However, the formation of national associations was largely motivated by, and derived its prestige from, associations' efforts to lobby the federal government for railroad tariff reductions, agricultural subsidies, and a uniform bill of lading law. In addition, many codification debate participants had very different incen- 
to lobby for the recognition of the trade practices most favorable to them. ${ }^{133}$ It is difficult to negate this possibility entirely. ${ }^{134} \mathrm{How}$ ever, even if rent seeking does account for the lack of consensus as to the content of some trade practices in certain industries, it is unlikely to account for all or even most incidences of disagreement. ${ }^{135}$ In addition, because all industry trade rules are default provisions that can be varied by contract, and because in many industries proposed rules had to be approved by the membership at large, with each firm getting one vote regardless of its size, the amount of rent that a group could capture through the rules creation process, relative to the rent it could capture through the contracting process and/or the custom creation process, is not so large. ${ }^{136}$

There are a number of additional reasons why rent seeking is unlikely to account for most disagreement about the content of customary practices. First, in industries that were composed of numerous local associations and exchanges before the formation of a national association, the written rules adopted by these small associations and exchanges differed widely. This gives some assurance that the debates relating to differences in customary practices reflected at least some real differences in the way that

tives from association executives. For example, much of the impetus for uniform written rules came from merchant arbitrators confronted with the need to decide cases. The prestige of the title "arbitrator" and the perceived legitimacy of these tribunals depended on the arbitrators resting their decisions on reasons that industry members would regard as proper, yet the arbitrators consistently lamented in their opinions and annual committee reports the lack of uniform customs that could be used to resolve disputes. Although it might be argued that this gave them an incentive to lobby for the adoption of rules, the position of arbitrator generally lasted only for a year or two, so it is unlikely that they would have an incentive to undermine the legitimacy of the tribunal today for a benefit that would accrue, if at all, only to those appointed to decide cases in the future.

${ }^{135}$ Indeed, in some industries, such as silk, this might have been a significant cause of disagreement. However, even if rent seeking did account for much of the disagreement over the content of customs, the existence of such disagreements would have serious consequences for the incorporation strategy. If rent-seeking attempts could not be distinguished from genuine differences in practice at association hearings, it is highly unlikely that an arbitration panel or court could make such a distinction in an actual case where the parties would also have strong financial incentives to lie.

${ }^{13}$ The actual opportunity to rent seek likely varied widely across industries due to differences in their voting rules, committee structures, and committee compositions (elected or appointed), as well as the order of their annual meeting agendas.

${ }^{185}$ In addition, if rent seeking was part of the process of codifying national rules, it might also have been part of the local rules creation process and the process of custom capture. It is therefore yet another force that works against rather than for the emergence of strong-form, pure Hayekian customs. See notes 176-77 and accompanying text.

${ }^{136}$ Some trade rules had to be separately approved by buyers and sellers associations. See, for example, ATMI and ACSA, Southern Mill Rules at 32 (cited in note 27). The WSRs were also separately approved by groups of buyers and sellers. See WSR 2 (1936) (listing sponsoring organizations). 
business was done in different parts of the country, rather than mere fabricated differences between rent-seeking industry subgroups. Second, the 1952 textile study found widespread disagreements over the meaning of usages of trade in a context where neither amending the rules nor deciding an actual case was at stake. ${ }^{137}$ The existence of similar disagreements in other industries such as grain, lumber, and silk are confirmed by articles in their trade press and/or similar surveys. ${ }^{138}$ Third, many of the codification efforts were motivated by a perceived need to make customs more uniform if misunderstandings were to be avoided and arbitration was to become an effective way to resolve disputes. If, however, the geographical scope of customs was coextensive with the geographical scope of efficient trade, and if these customs were, in fact, generally known and implicitly assented to, codification should not have been necessary to achieve predictable arbitral outcomes and avoid commercial misunderstanding. ${ }^{139}$ Fourth, contemporary interview evidence from the feed

\footnotetext{
${ }^{157}$ See Note, 61 Yale L $J$ at 700 (cited in note 85).

${ }^{138}$ For example, lumber associations conducted and published a number of surveys of trade practices that were not in any way related to the rules creation or amendment processes. These surveys found that industry members did not generally agree on the content of business practices. See, for example, NAWLA, Adjusting Salesmen's Commissions, North Coast Weekly Letter No 192 (Sept 29, 1925) (reporting the results of a fifty person survey asking, "Where a commission salesman is paid so much per $M$ on his sales and the customer claims a shortage of say, a few thousand feet, is it common practice to deduct the amount of the commission to be paid the salesman where an allowance is made covering such a shortage? Where a commission man is paid on a percentage basis, say five percent, and a claim for any reason allowed to customer, is a deduction, based on the allowance, made from commission paid?" and noting that "[t]he majority (35) state they do not think it is customary or good business policy to revise the commission where shortages or grade complaints develop. . . . Fifteen members stated they believed the salesman should stand his pro-rata of the deduction in both cases. . . The majority who answered the second question stated that where salesman is working on a percentage of the profits, the salesman should stand his share of any losses"; also reporting six statements of respondents setting out further nuances); NAWLA, Who Collects Rate Overcharges?, North Coast Weekly Letter No 193 (Oct 6, 1925) (noting similar divergence of opinion, correlated with the size of the firm, to the question: "When stock is bought f.o.b. mill basis on guaranteed weight, and the transportation company makes an overcharge in rate, is it up to the buyer to collect from the railroad, or should he charge the mill and let the mill collect claim?"). See also note 223 (discussing silk surveys).

${ }^{139}$ If the type of consensus about and widespread knowledge of the content of trade usages that is assumed by the Code is thought to consistently emerge in mercantile contexts, it is necessary to explain why, from at least the middle ages to the present, there have been so many attempts to codify mercantile customs. Bruce L. Benson, The Spontaneous Evolution of Commercial Law, 55 S Econ J 644, 649 (1989) ("[A]s the norms of [medieval merchant] commercial law became more precisely specified they were increasingly recorded . . . . not [in] statutory codes . . . . [but in] written commercial instruments and contracts."); Gerard Malynes, I Consuetudo, vel Lex Mercatoria: or the Ancient Law-Merchant a, a2 ("To the Courteous Reader") (T. Baffet 1685, repr Professional Books 1981) (compiling, in meticulous detail, trade practices and laws "[f]or the maintenance of Traffick and
} 


\section{trade in Texas suggests that even within the state, trade prac- tices regarding core contractual terms vary widely. ${ }^{140}$ Fifth, at as-}

Commerce [which] is so pleasant, amiable and acceptable unto all Princes and Potentates, that Kings have been and at this day are of the Society of Merchants: And many times, notwithstanding their particular differences and quarrels, they do nevertheless agree in this course of Trade .... Whereupon I have been moved, by long observation, to put the worthiness of the Customary Law of Merchants, in plain and compendious writing, by undoubted principles, familiar examples and demonstrative reasons"); A Member of the Massachusetts Bar, The Business Guide and Legal Companion 59, 60 (1845) (defining, like many commercial dictionaries, words like "hogshead," "barley corns," and "pennyweights"); J.R. McCulloch, 2 A Dictionary, Practical, Theoretical, and Historical, of Commerce and Commercial Navigation 720, 724 (Henry Vethake, ed) (Thomas Wardle 1841) (providing tables of weights and measures, and defining words and recording customs such as the custom "of allowing more than 16 ounces to the pound of butter [which] used to be very general in several parts of the country").

Today, the International Chamber of Commerce ("ICC"), a major provider of international arbitration services, has promulgated several quasi-official codifications of customs. One of the most important is the Incoterms, "a set of international rules for the interpretation of the chief terms used in foreign trade contracts, for the optimal use of businessmen who prefer the certainty of uniform international rules." ICC, Incoterms: International rules for the interpretation of trade terms 6 (ICC 1980). These rules acknowledge the undesirability of interpreting agreements by reference to custom, explaining that "[e]very endeavour has been made to limit such references to custom to the absolute minimum." Id at 8. However, noting that it has been "impossible to avoid [references to custom] altogether," the rules advise "the seller and the buyer ... to keep such general and particular customs in mind when negotiating their contract." Id. The Incoterms implicitly recognize that customs may be highly local in nature by including a default choice-of-custom provision, which provides that customary matters are to be "decided by the custom of the particular trade or port." Id. To further reduce uncertainty, the ICC has published several more particularized compilations of customs. See, for example, ICC, Uniform Customs and Practice for Documentary Credits, ICC Pub No 500 (1993); ICC, Uniform Rules for Collections, ICC Pub No 522 (1995); ICC, Uniform Rules for Contract Guarantees, ICC Pub No 325 (1978).

However, it is important not to attach too much weight to the possibility that the perceived need to write customs down suggests that customs are not sufficiently definite or uniform. There are a variety of other reasons, particularly in the trade association context, that the codification of custom might have been undertaken. First, when the relatively new national associations decided to adopt rules, they may have enhanced the legitimacy of the rules and reduced suspicion about the drafters' motivations by claiming that these rules were mere codifications of existing practices. Second, because most trade association arbitrators were industry participants, codification might have been viewed as useful for constraining some types of arbitral bias or making such bias easier to detect, thereby reducing arbitral discretion and enhancing the legitimacy and perceived fairness of the tribunals. Maintaining the tribunals' appearance of fairness was especially important prior to 1920 , when both ex ante agreements to arbitrate and arbitral awards were legally unenforceable. Third, because most arbitrators were not lawyers, codified rules enabled them to decide cases without having to familiarize themselves with the intricacies of sales law. Fourth, codification might have been viewed as necessary because, as the pace of technological and market changes increased, practices needed to change more quickly and in more coordinated ways than was possible through the slow accretion of custom. Finally, associations might have desired quality standardization and uniformity of trade practice because they can facilitate anticompetitive behavior.

${ }^{140}$ Interview with TGFA executive (1998) (on file with author); Interview with TGFA Board Member (1998) (on file with author); Discussant at TGFA Meeting (Feb 18, 1999) (explaining that the TGFA "Rules Committee didn't add certain truck rules because there 
sociations like the NHA, where proposed rules were subject to floor debate at the Association's annual convention, ${ }^{141}$ and debates were reported verbatim in the Association's Annual Report, there were publicity-based reputational constraints on debate participants. A transactor who suggested something was a custom when it was not risked reputational harm. If, for example, there was a custom that it was reasonable to take ten days to inspect goods before rejecting them, and a buyer stood up at the convention and said that it was reasonable to take twenty days, sellers would be wary of dealing with him in the future. ${ }^{142}$ If, however, the buyer could be sure that all other buyers would get up immediately and say twenty days, he might well engage in this type of distributional bargaining. In industries like silk, where the rules were the outcome of bargaining among groups of buyers and sellers who each deliberated in secret and then held a meeting between designated representatives of each group to negotiate the final rules, reputational constraints would have been much weaker, and the silk debates do indeed contain many instances of what might have been rent-seeking behavior. Sixth, some of the terms about whose meaning transactors disagreed have no distributive impact. For example, outside of the context of a specific dispute, a decision on how many days are meant by the terms "prompt" or "quick" does not have distributional implications, because most trade rules contained a menu of time designations to choose from. Seventh, in industries whose trade journals had columns where members could pose hypothetical questions to association executives, members often asked "what is the custom with regard to $X^{n 143}$

Finally, the testimony of representatives of the Commerce and Industry Association, ${ }^{144}$ a trade organization of merchants, in the hearings on the proposed Code provides support for the no-

were many different customs," but noting that this was "okay because trucks tend to travel in a $\mathbf{1 5 0}$ mile radius and people know how things are done in their area").

${ }^{141}$ In the early days of national trade associations, one of the main purposes of the annual convention was to form relationships and learn about the reputations of transactors in other localities. As a consequence, transactors attending these meetings were quite conscious of guarding their reputations.

${ }^{142}$ Similarly, in the grain industry where many merchants were buyers one day and sellers the next, they would have had no reason to skew the rules toward buyers or sellers.

${ }^{143}$ See, for example, Questions and Answers, 8 Silkworm 300 (Dec 1926) ("Is it customary to include in a contract with commission weavers a clause to the effect that the house must use only such quantities of yarns as are in accordance with the standards and rules of the Association."); Questions and Answers, 8 Silkworm 240 (Oct 1926) ("A piece goods manufacturer inquires if it is customary in the trade for the manufacturer to return the caps to the throwster.").

${ }^{14}$ Formerly the Merchants Association of New York. 
tion that customs did not exist and reveals that merchants were consciously aware of, and opposed to, the Code's incorporation strategy. The opinions they expressed were remarkably consistent with the arguments made during the intra-association codification debates, most of which had taken place many years earlier. For example, the Association's representatives objected to including "observance of reasonable commercial standards" in the Code's good faith provision, ${ }^{145}$ explaining that "the usages, customs and practices of business are far from being uniform, and the determination of whether a merchant has conformed to reasonable commercial standards would be difficult and would produce excessive litigation." ${ }^{\text {146 }} \mathrm{A}$ similar position was taken by the

\footnotetext{
${ }^{145}$ UCC \& 1-203 \& cmt.

${ }^{14}$ Commerce and Industry Association of New York, Inc ("CIANY"), Memorandum of Task Group of the Special Committee of the Commerce and Industry Association of New York, on the Uniform Commercial Code on Article 2, Sales and Article 6, Bulk Transfers, in Study of UCC Memoranda 24, 29, reprinted in State of New York, 1 Report of the Law Revision Commissioner for 1954 at 88-93 (cited in note 13). In addition, during the hearings, Professor John O. Honnold posed some questions to representatives of the Commerce and Industry Association of New York in an attempt to see if proposed Code provisions conformed to trade understanding of particular terms. In most of their responses, association representatives stated that practice was not "exactly uniform." For example, when asked about the meaning of "F.O.B. vessel," a representative noted, "while it is trade understanding in certain fields that the buyer must arrange for steamer space . . . in practical operation buyers customarily depend upon the sellers to make arrangements and ship via the most suitable and expeditious vessel available at the time the goods are ready for export." CIANY, Memorandum Replying to Questions Propounded by Professor Honnold at Law Revision Commission Hearing I-D, in UCC Memoranda at 67, reprinted in State of New York, 1 Report of the Law Revision Commissioner for 1954 at 131. In response to questions about the meaning of other proposed terms, the merchants said:

there appears to be a diversity of opinion as to inspection right where the contract terms are F.O.B. vessel' or 'F.A.S.' While the view has been expressed in a particular industry that the purchaser has the right to inspect goods before payment under such terms, the general export practice apparently is that the buyer has no right of inspection before payment unless there is specific prior agreement that such inspection or examination is required by the buyer. It is recommended practice that such prior agreement also specify whose account is to be charged for the cost of such inspection since such cost may be appreciable when the charges for inspection engineers, opening and closing constraints, and making goods available for examination are considered.
}

Id.

The Association also objected to part of the proposed Code's cure provision that gives the seller additional time to cure if he "had reasonable grounds to believe [the nonconforming tender] would be acceptable," UCC $\S 2-508(2)$, where the reasonableness of grounds is determined, in part, by reference to "prior course of dealing, course of performance, or usage of trade, ${ }^{n}$ id at cmt 2 . In its criticism of the provision, the Association explained, "There is no reason why a seller should ever believe that a non-conforming tender would be acceptable to the buyer." CIANY, Memorandum of Task Group, in UCC Memoranda at 37, reprinted in State of New York, 1 Report of the Law Revision Commissioner for 1954 at 101 . 
New York Law Revision Committee's Report on the Code. ${ }^{147}$ Thus, while Llewellyn justified the incorporation strategy on the grounds that it would make merchant law more accommodating to merchant concerns, the approach was not viewed in a positive light by the very merchants whose transactions it was designed to govern.

\section{Conclusion}

Although the evidence presented here has not conclusively demonstrated that the types of usages of trade, commercial standards, and industry-specific meanings of terms, referenced in the Code do not ever exist, it has suggested that the empirical foundation on which the Code in general, and its incorporation strategy in particular, is built may be weak. In addition, as the next Part suggests, the lack of consensus on the content of customary practices documented in the case studies is in no way surprising since there are a number of reasons to suspect that uniform customs relating to many aspects of a transaction would not exist. As a consequence, it is useful to reconsider the justifications for the Code's incorporation strategy and to look briefly at the ways that it has been invoked by parties and used by courts in decided cases.

\section{THE INCORPORATION STRATEGY REVISITED}

Code drafters and later commentators justified the pervasive incorporation strategy by noting that contracts are incomplete because rationality is bounded; because the transaction and strategic costs of including provisions dealing with all contingencies, particularly remote or unforeseen contingencies, are high; and

${ }^{17}$ The New York Law Revision Commission

was a little dubious about the widespread use of business terminology throughout the Code. Not that it has anything against business terminology as such-it's often very convenient-but it often lacks precision. It often means something in one part of the country, something else in another part, or as between different industries or lines of business.... [T] ]he Commission is anxious to see a statute that would have an ascertained or ascertainable meaning.

Panel Discussion on the Uniform Commercial Code, 12 Bus Law 49, 57 (1956). The Commission also expressed doubts about the anticipatory repudiation rules, explaining that "reasonable grounds for insecurity, adequate assurance of due performance [and] commercial standards," were terms that "should be more concrete, more specific. It did not like this resort to rather vague, uncertain, indefinite language." Id at 56-57. Even greater skepticism about the incorporation of trade usage was expressed in connection with the United Nations Convention on Contracts for the International Sale of Goods. See C.M. Bianca and M.J. Bonell, Commentary on the International Sales Law: The 1980 Vienna Sales Convention 105 (Giuffre 1987). 
because it is difficult to reduce the parameters of some obligations to a writing. They further maintained that customs are intended and understood by merchants to be an integral part of their agreement ${ }^{148}$ and that these customs, along with the merchants' course of actual performance under their contracts, provide the best indication of what they intend their writing to mean. ${ }^{149}$ In addition, at least with respect to using custom to fill gaps, the incorporation strategy has also been defended on the grounds that the provisions provided by custom are likely to be more efficient than those that a court could provide. A closer look at these justifications, however, suggests that they are based on inaccurate empirical assumptions and are theoretically weak.

A review of a subset of Code cases, from 1970 to the present, invoking the usage of trade provision ${ }^{150}$ reveals that very few alleged customs relate to remote or unforeseen contingencies. ${ }^{151}$ Most of the alleged customs relate to core aspects of any merchant transaction ${ }^{152}$ such as the permitted tolerance in quality; ${ }^{153}$

\footnotetext{
${ }^{14}$ See UCC $\$ 2-202$ cmt 2.

${ }^{10}$ See id at $\$ 2-208 \mathrm{cmt} 1$ (" $[\mathrm{P}]$ arties themselves know best what they have meant by their words of agreement and their action under that agreement is the best indication of what that meaning was.").

${ }^{100}$ See id at \$ 1-205. The sample includes cases in Uniform Commercial Code Case Digest para 1205.2(1) (West 1998), under the heading "Usage of Trade-In General" (excluding supplement). Eliminated were cases dealing with the secured financing aspect of the transaction; one case where the concept of a usage was simply contrasted with the concept of course of dealing, see Capitol Converting Equipment Inc v Lep Transport, Inc, 750 F Supp 862, 865 (N D Ill 1990) (where the course of dealing or usage dealt with terms of payment), affd, 965 F2d 391 (7th Cir 1992); and one case dealing with whether a contract existed that held the existence or nonexistence of any usages was irrelevant, see Wichita Sheet Metal Supply, Inc v Dhalstrom and Ferrell Construction Co, 246 Kan 557, 792 P2d 1043, 1049 (1990). Although the rather small number of cases in the digest category "Usage of Trade-In General" has led some to suggest that the Code's incorporation strategy is, as a practical matter, unimportant, this ignores the numerous other Code provisions and comments that incorporate usage of trade. See note 1.

${ }^{151}$ But see Cosden Oil \& Chemical Co v Karl O. Helm Aktiengesellschaft, 736 F2d 1064, 1076 (5th Cir 1984) (considering whether "a custom or trade usage relating to force majeure existed in the polystyrene industry").

${ }^{152}$ Most industry trade codes either require these aspects of a transaction to be covered by contract and/or provide bright-line gap-filling default rules relating to them. See, for example, Trade Rules of the National Hay Association Rule 1, in NHA, Report of the Twenty-Eighth Annual Convention 83 (1921) ("It shall be the duty of both buyer and seller to include in their original articles of trade, however conducted, the following specifications: Number of cars, tons, or bales. Size of bales. Grade of hay or straw. Price. Terms of payment. Rate basing point. Time of shipment. Route."); Grain Trade Rules Rule 1 (as amended Mar 13, 1995), in NGFA, Trading Rules and Arbitration Rules 3 (NGFA 1995) (noting that it is the duty of the buyer and seller to include in their contract or confirmation, the "(a) Date of contract; (b) Quantity[;] (c) Kind and grade of grain[;] (d) Price[;] (e) Type of inspection[;] (f) Type of weights[;] (g) Applicable Trade Rules to apply[;] (h) Transportation Specifications: (1) Type of conveyance; (2) Type of billing[:] Transit (storage or milling)[,] Non Transit[,] Export[,] Multi-car specifications[;] (3) Port of origin or delivery;
} 
the definition of the good to be exchanged, ${ }^{154}$ the time required for notice; the time for inspection and rejection:; ${ }^{155}$ the time, place, and manner of delivery; ${ }^{156}$ price and/or quantity adjustments; ${ }^{157}$ payment terms; ${ }^{158}$ and limitations on remedies. ${ }^{159}$ Nevertheless, even if courts looked to custom primarily to fill gaps when remote contingencies arose, this is precisely the type of situation in which incorporation is likely to yield the least desirable results. The more remote or unforeseeable a contingency, the less likely it is that there is an established customary practice covering it. Moreover, even if such a custom did exist, one would want to subject it to particularly exacting scrutiny. Assume for a moment, as the Code does, that customs are Hayekian in nature, gradually emerging over time from transactors' independent choices. ${ }^{160}$ Now

or rate basing point[;] (4) Loading weight requirements[;] (5) Time of shipment or delivery[;] (6) Route[;] (7) Responsibility for freight increases or decreases[;] [8] Buyer's and Seller's conveyance[;] (9) Type of bill of lading[;] (i) Payment terms; (j) Other terms").

${ }^{1 s s}$ Beachcomber Coins, Inc v Boskett, 166 NJ Super 442, 400 A2d 78, 80 (1979) (where the alleged custom related to quality verification usually undertaken before a purchase is final).

${ }^{13}$ Williams v Curtin, 807 F2d 1046, 1049 (DC Cir 1986) (where the alleged usage related to the meaning of the term "slaw cabbage" in a situation where one party contended it only meant "large cabbage" while the other contended that it meant "all cabbage suitable for making coleslaw"); Latex Glove Co v Gruen, 146 Ill App 3d 868, 497 NE2d 466, 470 (1986) (where the alleged usage went to the definition of good to be sold, specifically whether the sale of printed material included the sale of related by products of the printing process).

${ }^{15 s}$ Lackawanna Leather Co $v$ Martin \& Stewart, Ltd, 730 F2d 1197, 1201-02 (8th Cir 1984) (noting that the appellant sought to introduce usage defining what constitutes a reasonable time for inspection and revocation).

${ }^{158}$ Ore \& Chemical Corp v Howard Butcher Trading Corp, 455 F Supp 1150, 1152 (E D $\mathrm{Pa}$ 1978).

${ }^{157}$ Southern Concrete Services, Ine v Mableton Contractors, Inc, 407 F Supp 581 (N D Ga 1975) (finding that although the contract included price and quantity provisions, one party claimed a trade usage that these were to be treated as "mere estimates"), affd, 569 F2d 1154 (5th Cir 1978); Nanakuli Paving and Rock Co v Shell Oil Co, 664 F2d 772, 793 (9th Cir 1981) (alleged custom related to the price).

${ }^{158}$ Ore \& Chemical Corp, 455 F Supp at 1152 (where a battle of the forms issue turned on whether or not provisions in the plaintiff's confirmation dealing with "payment, loading Incoterms [Paris plus supplement]" were usages of trade); Union Building Materials Corp $v$ Haas and Haynie Corp, 577 F2d 568, 571 (9th Cir 1978) (where the alleged usage related to the terms of payment, specifically "whether the payment made to the subcontractor for materials delivered but not yet installed should include a proportion of the total overhead and profit for the job").

${ }^{169}$ Western Industries, Inc $v$ Newcor Canada Ltd, 739 F2d 1198, 1201 (7th Cir 1984) (discussing an alleged "custom of the specialty welding machine trade [ ] not to give a disappointed buyer his consequential damages but just to allow him either to return the machines and get his money back or (for example if the breach consists in delivering them late) keep the machines and get the purchase price reduced to compensate for the costs of delay"); Posttape Associates v Eastman Kodak Co, 450 F Supp 407, 410 (E D Pa 1978) (discussing "a trade usage limiting a commercial buyer's remedy to replacement of the negligently manufactured film").

${ }^{100}$ See notes 176-77 and accompanying text (discussing Hayek's views on the evolution 
consider how a pair of transactors will decide to act when a remote contingency arises. In such a situation, each transactor will reason that the likelihood that this situation will arise again is, by definition, remote, so that even if she is a buyer one day and a seller the next, she should fight for the outcome that gives her the greatest share of the pie today, rather than the outcome that will, over time, maximize the size of the pie. ${ }^{161}$ As a consequence, to the extent that patterns of practices dealing with remote contingencies arise, they may favor stronger or particular types of firms.

The review of these Code cases also suggests that the limits of language were unlikely to have been a significant barrier to transactors' memorializing the asserted usages in written provisions. In none of the cases surveyed did either party have any difficulty expressing the content of the usage in clear terms. ${ }^{162}$ Moreover, the codification debates contain no indication that there were rules that drafters would have liked to include, but that could not be adequately expressed in words. ${ }^{163}$ In addition,

of custom).

${ }^{161}$ If, however, the happening of the contingency and the way it is dealt with by these transactors are observable to members of the relevant market, a transactor concerned about her reputation might act in the most advantageous way that will be regarded as "fair." Alternatively, a single very general custom such as "share the loss" might evolve to deal with large groups of unforeseen contingencies, but again there is no reason to think that this allocation of losses will create desirable incentives. Nevertheless, unforeseen contingencies, at least in domestic merchant industries, are quite rare since most trade rules cover adverse weather, labor, transportation, and financial events, making most remaining unforeseen contingencies quite remote.

${ }^{102}$ It is, however, important to note that the cost of capturing a usage in writing ex ante is likely to be higher than the cost of giving it content ex post; and the cost of giving it content ex post need only be incurred if the relationship breaks down and the parties disagree about its content. In addition, an ex ante provision memorializing a usage might have to be more complex than an articulation of a custom ex post since it might have to cover numerous preconditions and situations that would be irrelevant ex post. If, however, complexity and nuance are to be invoked as reasons not to memorialize the usage in a contract, but to nevertheless incorporate it as an enforceable part of an agreement, it is important to note that as the complexity of and number of contextual preconditions to a usage increase, the likelihood that there is reasonably widespread consensus about its content, and that its content can be accurately determined by a court, decreases. In addition, there are unrecognized costs of not capturing the usage in writing ex ante, such as a greater risk of misunderstanding and subsequent transaction breakdown, as well as the costs of the overly high or overly low precautions that the transactors might take if they do not clearly understand their obligations.

${ }^{103}$ The only possible exceptions are the debates relating to grades. While the limits of language were not invoked as reasons for the inability to arrive at a consensus over how to memorialize the description of a particular grade in a rule, and most associations either promulgated standardized written descriptions of quality-see, for example, Grades of Hay and Straw Established by the National Hay Association, Inc., in NHA, Report of the Twenty-Eighth Annual Convention 161 (1921) ("No. 1 Timothy hay-Shall be timothy containing not more than one-eighth clover or other tame grasses, bright color, sweet, sound and well baled.")-or relied on descriptions provided by the government-see Official 
when the lumber industry newsletter reported arbitration decisions in cases arising from a disagreement about "custom of the trade," the case report would frequently be accompanied by a suggested contract clause that could be used to avoid misunderstandings in the future. These clauses did not typically include linguistically complex formulations. ${ }^{164}$ Finally, even if it is linguistically difficult to capture particular aspects of the desired performance in words, the incorporation of trade usage may not

United States Standards for Grain, 7 CFR Part 810 (1998)-the fact that rules expressed in words could not ensure uniform grading given the subjectivity of the determinations that had to be made was an implicit theme of the debates. Nevertheless, this subjectivity did not lead the associations to direct arbitrators to incorporate custom on the question of quality. Rather, most trade rules provided for quality disputes to be resolved by wisemanlike intermediaries, some run by the industry, as in the green coffee industry-see, for example, Green Coffee Association of New York City, Inc, Rules of Arbitration (1989); ATMI and ACSA, Southern Mill Rules Rules 43-44 at 18 (cited in note 27)-and some run by the government, as in the grain industry by the Federal Grain Inspection Service. For an overview of the program, see Tuttle v Missouri Department of Agriculture, 1999 US App LEXIS 5445, *2-5 (8th Cir).

It is, however, important to note that wholly apart from the inability to fully capture grade categories in words, there were a number of other possible reasons for using separate quality intermediaries. First, to the extent that quality determinations are more subjective than rulings on other aspects of contractual performance, the use of a separate quality intermediary might be designed to guard against arbitral bias. Most rules governing industry-run quality arbitration tribunals contain procedural safeguards against bias that are not used in regular arbitrations for breach of contract, such as not telling the arbitrators the names of the parties. See, for example, Green Coffee Association of New York City, Inc, Rules of Arbitration R VII(I), VIII (1989). Second, because disagreements about quality are likely to arise even if everyone is acting in good faith, the availability of a tribunal that can objectively make this determination even before an action for breach is instituted should help promote cooperation. In practice, the use of a quality intermediary, particularly in those industries where the assessment of quality is subjective, is not particularly damaging to commercial relationships as long as recourse to it is not too frequent. This may be because transactors understand that two people acting in good faith might have different assessments of quality. Interview with Cotton Merchant (July 1996) (on file with author). Finally, the use of quality certification intermediaries may promote settlements in disputes where breach of contract for delivering improper quality is alleged. Having a wiseman determine quality effectively bifurcates the arbitration. In addition, with the issue of liability clear, and damages under these rules being determined using objective measures that do not require the revelation of firm-specific information, parties have all the information they need to settle the suit. See Bernstein, Private Commercial Law (cited in note 13) (noting that the damage rules of the cotton industry and many other industries do not require the revelation of firm-specific information).

${ }^{\text {ist }}$ See, for example, NAWLA, Make this Test!, North Coast Weekly Letter No 217 (Apr 6,1926 ) ('Where lumber is bought at certain prices 'less 5\%' the usual clauses used are found to be ambiguous and lead to unnecessary controversies at times. In order to comply with the usual custom in such cases and avoid misunderstanding, the following clause is suggested: ... Prices are f.o.b. mill; underweights to mill; less $5 \%$ after deducting actual freight."'); NAWLA, Questions and Answers, North Coast Weekly Letter No 225 (June 22, 1926) ('T T $]$ he term 'a carload' is broad indeed and its interpretation by different persons and under different conditions leads to much trouble. The following qualifying clauses are suggested to avoid misunderstanding: Clause No. 50: 'Load between 25,000' and 30,000' on this order.' Clause No. 51: Not over _ M $\mathrm{ft.”}$ ). 
be a desirable response. The Code requires the content of a usage to be established as "fact,"165 something that it is difficult to do if the custom cannot be adequately expressed in words. As a consequence, it might be better to encourage transactors to include a wiseman provision in their contracts, designating an industry expert who will make the necessary determinations in the event of a dispute. If the wiseman's determinations were made binding in any litigated disputes, the wiseman would, in effect, function as a privately contracted-for merchant jury. ${ }^{166}$

As regards the Code's premise that merchants in fact consider usages to be fully part of their agreement, the case studies of the incorporation debates, together with the text of trade rules, articles from the trade press, merchant testimony on the proposed Code, and the moderm adjudicative approaches of many merchant tribunals suggest that merchants did not view written and unwritten custom, much less unwritten custom and written contract provisions, as being on par with one another.

First, not all customs were included in the trade rules. This suggests that some were viewed as suitable or desirable for thirdparty enforcement while others were not. ${ }^{167}$ Second, some rules, like the WSRs, explicitly distinguished between written and unwritten custom in their hierarchy of authority for interpreting contracts. ${ }^{168}$ Third, the trade press in various industries is filled with statements that a practice may be customary but that those who want it to be followed should include a provision to that effect in their contracts. ${ }^{169}$ Fourth, in the rare instances that early

${ }^{106}$ UCC $\S 1-205(2)$ ("The existence and scope of . . . a usage are to be proved as facts" by the litigant, who must then apply it to the circumstances of the case.).

${ }^{106}$ Llewellyn's early drafts of the Code contained a merchant jury provision that would have permitted the submission of many types of determinations to merchant experts whose decisions would be binding at trial. See Wiseman, 100 Harv L Rev at 527-29 (cited in note 4).

${ }^{107}$ In addition, the records of interassociation debates relating to amendments to the Southern Mill Rules, a set of rules governing cotton transactions between merchants and mills that are jointly drafted by the American Cotton Shippers Association ( ACSA"), a $^{n}$ trade association of merchants, and the American Textile Manufacturers Institute ("ATMI"), a trade association of mills, suggest that there were practices each association was willing to encourage its members to abide by, but that they refused to include in the rules as legally enforceable obligations. See, for example, Minutes of the 1990 ACSA/ATMI Joint Meeting 3 (June 19, 1990) (while the ATMI rejected a proposed ACSA rule dealing with sample approvals, the "ATMI did agree to notify its members regarding shippers' concerns with sample approvals"); Minutes of Joint ACSA-ATMI Meeting 4 (June 8-9, 1981) (unpublished document, on file with author) (noting that "ATMI rejected any change in the rules [relating to rejections], but advised that they would ask ATMI members to handle rejections in a more expeditious manner").

${ }^{160}$ See note 100 and accompanying text.

${ }^{10}$ See, for example, Pacific Coast Shippers Association ("PCSA"), The Secretary's Weekly Letter No 82 (July 24, 1923) ("When a wholesaler orders lumber from an inland 
trade codes contained provisions directing arbitrators to take custom into account, a choice of custom provision was often included in the rule. ${ }^{170}$ The inclusion of such provisions suggests that merchants recognized that customs varied from locality to locality. Fifth, there is a great deal of evidence that the practices that some industry participants described as customs were viewed by others as undesirable practices that ought to be changed, not as ideal, implicit contract provisions. ${ }^{171}$ Sixth, when testifying on the proposed Code, merchants took the position that even practices that were almost universally followed in day-to-day relationships should not necessarily be written into law. For example, merchants acknowledged the practice of giving a price adjustment for nonconforming tender, but argued strongly for retention of the perfect tender rule, explaining that "the price adjustments that merchants made when goods 'are not entirely up to standard'the give and take of ordinary mercantile life'-should not be made obligatory in the law. ${ }^{m 172}$

mill for delivery at a port for shipment by water, while it is customary for such shipments to be loaded on open equipment, it is not obligatory on the part of the mill who is allowed to use any available equipment unless it is specifically stated on the order that stock must be loaded on open equipment.").

${ }^{170}$ See, for example, Rule 5, 11 WWGT 35 (Nov 5, 1921-22) ("[B]illing instructions must be furnished the Railroad Company in accordance with the custom then in vogue at the shipping point."). See also ASTA, 1955 Yearbook 193 ("In the absence of any specific stipulation in the contract of sale or purchase applying to the type of package or packaging, it will be presumed that the custom prevailing in the area of production will apply."). But see Trade Rules of the Grain Dealers National Association Rule 36(e), 10 WWGT 40 (Nov 20, 1920-21) (requiring brokers to negotiate "in accordance with the rules and customs governing such transactions"). Similarly, when answering questions involving custom, the NGFA was also careful to specify which locality's custom governs. See Secretary's Book (no page number, dated 1903) (cited in note 59) (stating that when the Trade Rules committee was asked, "[s]hould a receiver charge seller commission on grain failing to grade to contract when shipper orders elsewhere," it "recomm[ended] that the usage of the market to which the grain may have been consigned shall govern").

${ }^{172}$ See, for example, notes 127-29 and accompanying text (silk); ASTA Yearbook 30-31 (1910) (where a member stated, "I wish to call your attention to a custom that prevails among the Seed Trade, and which seems entirely unnecessary. It is the long term Credit on Garden Seed. There really is no reason for this custom .... This is a relic of the old days, and out of line with present day business methods, and is well worthy of your serious consideration," and further noted that the custom may survive because it gives the "well established house a little advantage that his newer competitor finds hard to meet"). However, simple cognitive bias towards doing things in the traditional way may also have played a role in locking in traditional practices. See, for example, Misuse of Order Bill of Lading: Shippers Should Stop Improper Practices-Following Old Customs Without Knowing Why, 10 WWGT 30 (Feb 20, 1921-22) ("[M]any shippers are following a custom which has prevailed for years without knowing why or having any good reason for doing so. In many cases, the shipping clerk is merely following precedent without knowing why."). See also text accompanying notes 127-29 (silk).

${ }^{172}$ Wiseman, 100 Harv L Rev at 526 (cited in note 4). In arguing for the perfect tender rule, merchants explained that the type of buyer opportunism made possible by the rule 
Finally, modern merchant tribunals are, for the most part, very wary of taking unwritten custom into account in deciding cases. ${ }^{173}$ Although they will sometimes look to it when faced with a true contractual gap, they have a much narrower conception of a gap than courts applying the Code, and they will almost never look to custom to interpret or vary a provision in a written contract or memorandum. ${ }^{174}$ In those instances when industry expert arbitrators do look to customs, they sometimes signal their discomfort by criticizing the contracting practices of the parties.

could "take care of [itself] 'mighty quick' through other merchant practices." Id. In sum, '[i]n the merchants' view, the combination of the perfect tender rule and nonlegal sanctions was more advantageous than a rule of substantial performance with judicial discretion." Bernstein, $144 \mathrm{U} \mathrm{Pa} L$ Rev at 1801 (cited in note 13).

${ }^{173}$ See Bernstein, $144 \mathrm{U} \mathrm{Pa} \mathrm{L}$ Rev at 1801 (cited in note 13); Bernstein, Private Commercial Law at 10-11 (cited in note 13).

In the early days of their operation, however, these merchant tribunals looked to custom more often. There are a number of possible explanations for the initial use and gradual abandonment of incorporating custom for any purpose other than filling a pure contractual gap. First, even in the past, customs were not typically looked to for the purposes of varying terms or defining the meaning of written provisions, but rather to fill gaps. Because many early sets of rules were less detailed than modern trade rules, and written contracts tended to be less complete, perhaps because most firms were small and more trade was local and personal, there were more gaps to be filled. See No Change in Rules, 20 WWGT 34 (Nov 30, 1930-31) ("I have been chairman of the Rules Committee for a number of years and it is very noticeable that suggestions for changes and inquiries for interpretation are becoming fewer each year. It is possible that this may be because my opinions are not of value, but I prefer to believe that it is because of a constantly increasing understanding of the mutual obligations and customs over different sections of the country, and through the Grain and Feed Dealers National Association a uniform and fair interpretation of rules and custom."). Second, in the early years more trade was local in scope, so those local customs that did exist may have been a sound basis for deciding cases. It is, however, important to exercise caution in drawing a straight inference that because merchant tribunals rejected incorporation, the public commercial law should as well. Merchant associations have institutional alternatives available to help solve the problems of contractual incompleteness that are unavailable in the public legal system. They can promulgate multiple sets of trade codes, carefully tailored to different types of transactions, as well as standard form contracts that are even more closely tailored to particular contexts. In addition, they can draw on pre-existing forces of shaming and social suasion to encourage and discourage particular types of behavior, forces that are unavailable to either courts or to many of the industries whose contractual relations are governed by the Code. See, for example, Lisa Bernstein, Opting out of the Legal System: Extralegal Contractual Relations in the Diamond Industry, 21 J Legal Stud 115 (1992); Bernstein, Private Commercial Law at 16-25. However, because merchants testifying on the proposed Code sharply criticized the incorporation strategy-see notes $144-47$ and accompanying text-the fact that most of their private legal systems reject this strategy is nonetheless quite telling.

${ }^{174}$ Bernstein, $144 \mathrm{U} \mathrm{Pa} L$ Rev at $1775-80$ (cited in note 13). The NGFA arbitrators also do not permit custom to trump trade rules, even though the rules are said to be based on customary practices. See, for example, Texas Farm Products Co v Topeka Mill \& Elevator Co, NGFA Case No 1507 (NGFA 1970) ("While trade practices in the Kansas City area may differ in accepted meaning of terminology" from the practices in Texas, "this does not relieve the Seller from complying with Rule 38 unless so specified in writing."). See also note 217. 
More generally, merchants appear to have a clear sense that practices will often vary from contract provisions, sometimes in systematic and sometimes in relationship-specific ways, but that these variations should be left to the extralegal realm for their enforcement and. are essentially irrelevant to any dispute requiring third-party adjudication ${ }^{175}$

The Code's incorporation strategy has also been defended on the grounds that, at least as regards the gap-filling use of custom, customs are likely to be more efficient than any term the court can construct. The strength of this argument, however, depends strongly on acceptance of the strong-form Hayekian view of the evolution of custom that implicitly animates the Code, a view that suggests that efficient custom should evolve through the natural selection of rules and practices. ${ }^{176}$ This is, however, a view of custom that Hayek himself doubted in its purest form, ${ }^{177}$ and that seems increasingly untenable in light of the insights of modern game theory and cognitive psychology. Game theory makes clear that regularities in behavior can emerge from sets of circumstances vastly different from those envisioned by Hayek. For example, customs may reflect the unique or nonunique equilibria that are produced by interactions characterized by any of a number of games. These equilibria may or may not be efficient. Their evolution may also be highly path-dependent and strongly influenced by information cascades ${ }^{178}$ or any of a number of heuristic

\footnotetext{
${ }^{175}$ For an extensive discussion of this point and supporting evidence, see Bernstein, $144 \mathrm{U} \mathrm{Pa} \mathrm{L}$ Rev at 1777 \& $\mathrm{n} 43$ (cited in note 13).

${ }^{176}$ See F.A. Hayek, 1 Law, Legislation, and Liberty: Rules and Order 35-54, 74-91 (Chicago 1973). However, Hayek himself recognized that rules arising from an evolutionary process may "develop in very undesirable directions, and [ ] when this happens correction by deliberate legislation" may be "the only practicable way out." Id at 88.

${ }^{17}$ Id at 100-01 (noting that for the best rules to emerge both the evolutionary forces of spontaneous order and the actions of courts and legislature are all necessary, explaining that "the system of rules as a whole ... is the outcome of a process of evolution in the course of which spontaneous growth of customs and deliberate improvements of the particulars of an existing system have constantly interacted").

${ }^{178}$ See David Hirshleifer, The blind leading the blind: Social influence, fads, and informational cascades, reprinted in Mariano Tommasi and Kathryn I. Ierulli, eds, The new economics of human behavior 188, 191 (Cambridge 1995) ("[A]n informational cascade occurs when the information implicit in predecessors' actions (or resulting payofis) is so conclusive that a rational follower will unconditionally imitate them, without regard to information from other sources. ... [C]ascades often spontaneously develop on the basis of very little information. People converge on one action quite rapidly, and their decisions are idiosyncratic."). Because information cascades arise when people give relatively large weight to the behavior they observe around them, information cascades may well explain the existence of highly localized customary practices that differ widely from locality-tolocality in ways that cannot be explained purely in terms of transactional differences or other efficiency related criteria. See President Clement Makes Committee Appointments, 10 WWGT 25 (Nov 20, 1921-22) (stating that outside the context of a particular dispute,
} 
biases. ${ }^{179}$ Although game theory also suggests that the usages reflected in some of these types of equilibria are unstable and can therefore be changed easily if they are thought to be undesirable, there are a number of forces that operate on commercial practices-including the heuristic biases that helped create them as well as coordination problems and interpretive, educational, and enforcement-related network externalities ${ }^{180}$ - that make it less likely than game theory would predict that trade practices, whether written or unwritten, that survive for a certain period of time are going to change. ${ }^{181}$

Moreover, even if customs did arise through Hayekian-type natural selection, there is no reason to think that they would pro-

how the terms "prompt," "quick," and "immediate" are defined when transactors are given a menu of time provisions to choose from has no distributional consequences). Although the theory of informational cascades shows that the results of the cascades are vulnerable to change, commercial customs established by cascades are subject to the same lock-in forces as other commercial customs, and in practice are therefore less likely to change in response to the introduction of new information than the models would suggest.

${ }^{173}$ See, for example, Marcel Kahan and Michael Klausner, Path Dependence in Corporate Contracting: Increasing Returns, Herd Behavior and Cognitive Biases, 74 Wash U I Q 347 (1996) (discussing how cognitive biases, including the status quo bias, the endowment effect, anchoring bias, conformity bias, and herd behavior, influence contracting decisions and reinforce recourse to standard written terms). Transactors may be particularly wary of suggesting departures from custom in markets where such suggestions are rare, since the relational costs of doing so are likely to be particularly high.

${ }^{100}$ Interpretive network externalities are the benefits created by the fact that, as compared to the meaning of a specially drafted provision, the meaning of a widely used contractual provision is likely both to be clearer (since it has already been interpreted by courts) and to become clearer over time (because it will be more likely to be interpreted by courts in future disputes). See generally Michael Klausner, Corporations, Corporate Law, and Networks of Contracts, $81 \mathrm{Va} L \mathrm{~L}$ Rev 757, 775-79 (1995). An educational network externality is the increased certainty and reduced chance of misunderstanding and transaction breakdown that result from using the standard terms provided by the trade rules, terms that trade associations go to great lengths to explain to their members and that receive wide coverage in the trade press. See text accompanying notes 229-30. The enforcement network benefit follows from the interpretive and educational network benefits. When most market transactors understand a term, and the violation of that term is either observable to market participants or can be credibly revealed to them at moderate cost, multilateral reputational sanctions can be imposed on the breacher. These sanctions depend for their effectiveness on widespread consensus about the standard used to assess whether or not behavior was proper. In contrast, unusual terms, whether written or unwritten, are backed primarily by legal sanctions, bilateral reputational sanctions (most commonly termination of trade), and some negative gossip. This, in turn, creates a preference for standardized legal and extralegal terms.

${ }^{181}$ Indeed, the trade press and association records in many industries suggest that it was extraordinarily difficult to change custom, see note 129 and accompanying text, and that customs that no longer made even a modicum of business sense were often followed. Misuse of Order Bill of Lading, 10 WWGT 30 (Feb 20, 1920-21) ("A are following a custom which has prevailed for years without knowing why or having any good reason for doing so. In many cases, the shipping clerk is merely following precedent without knowing why."). 
vide desirable, legally enforceable contract provisions. ${ }^{182}$ In the absence of an authority who stands ready to promulgate and enforce customs, a custom will develop only if it was first a practice that was followed by a pair of transactors who found it in their best interest to do so. ${ }^{183}$ The first time the practice was followed, it would have been legally unenforceable since it would be neither a course of performance nor a course of dealing. As a consequence, the practice could only condition on information that was observable to the transactors. ${ }^{184}$ Without the threat of legal compulsion, a practice that conditioned on information that was only verifiable, ${ }^{185}$ that is, a practice whose applicability could only be determined by a third party who could compel the parties to reveal information, would not be workable. So even if customs were perfect Hayekian customs that arose from the force of natural selection operating on practices, there is no reason to expect them to be optimal legally enforceable contract provisions or necessarily better provisions than a court could construct using any of a number of interpretive methods. ${ }^{186}$

\footnotetext{
${ }^{182}$ See Posner, $144 \mathrm{U}$ Pa L Rev at $1705-25$ (cited in note 9) (discussing the possibility and potential causes of inefficient norms).

${ }^{183}$ However, it is possible that under the Code a practice that came into being by conditioning only on observable information might, as it evolved first into a course of performance, then into a course of dealing, and finally into a custom, come to condition on information that was a verifiable proxy for the observable information that the practice originally conditioned on. This process of transformation would likely be accelerated by parties' attempts to enforce these practices in court, since in each dispute the parties would be required to adduce verifiable information in support of their claim. As a custom comes increasingly to condition on verifiable information, unless the observability conditions concurrently survive the evolution, the cooperation-promoting aspect of the custom will begin to disintegrate.

${ }^{13}$ Observable information is information that the transactors themselves can obtain at the relevant time at a cost they regard as reasonable ex ante. The observability of a condition may change over the life of a contracting relationship as the transactors learn about one anothers' operations, thereby expanding, over time, the extralegally contractible aspects of the deal.

${ }^{185}$ Verifiable information is information that transactors would, ex ante, view as both possible and financially desirable to prove to a third party in the event a dispute arose. See Alan Schwartz, Relational Contracts in the Courts: An Analysis of Incomplete Agreements and Judicial Strategies, $21 \mathrm{~J}$ Legal Stud 271, 279 (1992). Some observable information is also verifiable, but not all verifiable information is observable.

${ }^{168}$ The preference for contract over unwritten custom in trade associations is, however, influenced by considerations that may play out differently in the legal arena. While unwritten customs are subject to the lock-in forces and other cognitive distortions discussed in the text, most of these forces also operate in largely the same way on written contractual provisions in industries without trade rules or centrally drafted contractual forms. See Klausner, $81 \mathrm{Va} L \operatorname{Rev} 757$ (cited in note 180). The only difference is that written provisions containing customary understandings can initially condition on verifiable information. If one thought that lock-in forces caused more inefficiency in written terms than in unwritten terms, it might be desirable to interpret written provisions by reference to unwritten custom as the Code directs. If, however, one thought that unwritten customs were
} 
More generally, both the Code's incorporation strategy and the dominant evolutionary views of the emergence of custom are based on the same curious assumption. Namely, if most transactors in a market could costlessly arrive at and draft a term governing an issue, they would likely arrive at the same term, the customary term. Nevertheless, in many, if not most, contractual settings, this assumption is likely to be false. Transactors are likely to have different perceived trade-offs between price and other terms, different abilities to use slightly imperfect goods, different abilities to finance their cash gap, and different risk preferences. There is no reason to suppose that, given these differences, all transactors would choose the same contractual provisions. ${ }^{187}$ Indeed, even in cash commodity sales that are relatively standard as compared to many of the transactions governed by the Code, trade rules typically offer transactors a menu of possible terms for each core aspect of their trade. ${ }^{188}$

more subject to these forces, it would be undesirable to look to them unless faced by an unambiguous gap. In trade associations, however, the trade rules creation and amendment processes, and the widespread use of association-drafted standard forms, means that written contractual provisions can be more readily changed and are less subject to lock-in forces than both unwritten custom and perhaps written contracts in nonassociation dominated markets. Indeed, the decision of trade associations to create written sets of trade rules might be understood as an efficiency-enhancing institutional response to problems inherent in the evolution of both custom and individually drafted contracts. See Bernstein, Private Commercial Low at 28-30 (cited in note 13).

${ }^{15}$ In addition, it is likely that transactors in a given market will have more defined transaction types in their mind than a court will, and how exactly the court defines the type of transaction perceived to be at issue may, as Craswell has argued, be outcome determinative. Craswell, Do Trade Customs Exist? (cited in note 8). Yet it is quite likely that this is the type of determination a court will get wrong. Consider a contract between a merchant-seller of cotton and a mill-buyer. There are many mills that produce a variety of goods, depending on the demand of their customers. Suppose the mill sometimes makes sheets, and that when it does it is terribly important that a particular quality of cotton is used. Other times it makes denim, a production process where quality is much less important. A court attempting to find a trade custom relating to the permissible quality variation might well aggregate over both types of transactions, yet one would not expect the optimal amount of quality variation to be the same in contracts for goods to produce sheets as in contracts for goods to produce denim. Or, consider a contract for the sale of silk. A court might not distinguish between a contract for silk to be used to make gloves and other types of silk, yet in the silk trade, when it comes to payment time, the difference is outcome determinative. Compare Standard Rules of the Silk Glove Group Rule 4, in Organization of Glove Silk Group, 2 Silkworm 17 (Mar 1921) ("Shipment made within one week after specified date of delivery shall constitute good delivery.") (emphasis added); with Broad Silk Rules Adopted, 2 Silkworm 10 (January 1921) ("Rule 5 . . shipment made within two weeks after specified date of delivery shall constitute a good delivery.") (emphasis added).

${ }^{128}$ See, for example, NGFA, Trade Rules and Arbitration Rules Grain Trade Rule 8 ("Time of Shipment or Delivery") (1995) (defining a selection of time designations including "immediate," "quick," "prompt," and "first half of the month shipment"); id at Rule 4A (defining several weight classifications to choose from); id at Rule 4B (setting out several types of inspections). 
Moreover, the Code's incorporation strategy reflexively incorporates customs into all contracts in a market, unless the customs are clearly and specifically negated, ${ }^{189}$ and looks to customs to interpret even explicit and facially unambiguous contract provisions. ${ }^{190}$ It thereby moves the meaning of explicit provisions as close as possible to the meaning of customary terms, ${ }^{191}$ and in so doing transforms many customary practices into quasimandatory standardized provisions in all contracts in the rele-

${ }^{189}$ UCC § 2-202 cmt 2 ("Unless carefully negated [usages of trade] have become an element of the meaning of the words used."). In addition, because the duty of good faith cannot be "disclaimed by agreement," id at $\$ 1-102(3)$, and because the comment notes that the good faith requirement is to be "implemented by Section 1-205 on course of dealing and usage of trade, ${ }^{n}$ contracting out of trade usage is quite difficult. Id at $\$ 1-203 \mathrm{cmt}$.

${ }^{190}$ See Nanakuli Paving, 664 F2d at 794-805 (binding seller to trade usage where a contract for the sale of asphalt contained an explicit provision that stated that the seller's posted price at the time of delivery would govern, but the buyer claimed that it was entitled to "price protection"- a usage of trade in the asphalt-paving trade in Hawaii that required the seller to sell at the original price all the asphalt that the buyer had committed to use in jobs on which it had already bid in reliance on the seller's price). See also Columbia Nitrogen Corp v Royster Co, 451 F2d 3, 7 (4th Cir 1971) (holding that, despite express price and quantity terms and a standard integration clause, evidence to show that it was a custom and usage of the fertilizer industry that "express price and quantity terms in contracts for material ... are mere projections," was admissible to establish a consistent, additional enforceable term in the parties' agreement); Sherrock v Commercial Credit Corp, 277 A2d 708, 711 (Del Super 1971) (finding buyer to be a merchant buyer and therefore obligated to follow reasonable commercial standards in the trade, and holding that the buyer's decision to pay early and let seller retain possession for several days thereafter was not in accordance with the custom of the automobile trade and was unreasonable, explaining that "departures from customary usages and commercial practices should be viewed as strong indicia that the practice is not reasonable"), revd on other grounds, 290 A2d 648 (Del Super 1972).

${ }^{191}$ Llewellyn's preference for moving the meanings of terms and obligations as close as practicable to their customary meaning is amply reflected in the legislative history of the Code. In a comment on a proposed draft of the Code, Llewellyn wrote:

No inconsistency of language and background exists merely because the words used mean something different to an outsider than they do to the merchants who used that language in the light of the commercial background against which they contracted. This is the necessary result of applying commercial standards and principles of good faith to the agreement . . . Moreover, where the commercial background normally gives to a term in question some breadth of meaning so that it describes a range of acceptable tolerances rather than a sharp-edged single line of action, any attempted narrowing of this meaning by one party is so unusual as not likely to be expected or perceived by the other. Therefore, attention must be called to a desire to contract at material variance from the accepted commercial pattern of contract or use of language. Thus, this Act rejects any "surprise" variation from the fair and normal meaning of the agreement.

Cited in Dennis M. Patterson, Good Faith, Lender Liability, and Discretionary Acceleration: Of Llewellyn, Wittgenstein, and the Uniform Commercial Code, 68 Tex I Rev 169, 200 (1989).

For a carefizl discussion of the jurisprudential inseparability of the Code's duty of good faith, its reliance on usage, and its definition of agreement, which traces the evolution of these ideas in Llewellyn's thought and through drafts of the Code, see id at 199-202. See also Bernstein, $144 \mathrm{U} \mathrm{Pa} L$ Rev at 1782-87 (cited in note 13). 
vant market. ${ }^{192}$ It also prevents transactors from actually following a custom that they perceive as a desirable, legally unenforceable practice, but undesirable legally enforceable contract provision, because if they follow the custom on more than one occasion, it would likely be transformed into a legally binding course of dealing or course of performance. In addition, if there are, in fact, customs that cannot be linguistically captured in a contract provision ex ante, the incorporation strategy transforms them into mandatory terms because in order to be excluded, the contract

${ }^{192}$ Although the incorporation strategy implicitly treats many customs as terms in standard form contracts, often referred to as contracts of adhesion, customs do not, for the most part, engender similar distrust. But see Danzig, 27 Stan L Rev at 626-27 (cited in note 6). Although many of the objections to standard form contracts are untenable from an economic point of view, these objections are widely accepted, so it is important to note that they provide an even stronger ground for objecting to implicit, customary, standard form contract provisions.

The two main grounds for distrust of standardized contracts are "[flirst, [that] most persons presented with standardized forms do not bother to familiarize themselves with the specific content," and "second, [that] because the advantages of forms would be lost if bargains were open to routine renegotiation, their users are often unwilling to do business on other than standard terms." Avery Weiner Katz, Standard Form Contracts, in Newman, ed, 3 The New Palgrave Dictionary at 502 (cited in note 21). Both of these concerns are even more problematic in relation to custom. First, the per transaction cost to a transactor of reading a standard-form contract drafted by someone he does business with frequently is small in comparison to learning all of the practices in vogue in the other transactor's market. Indeed the cost, difficulty, and bother of learning the practices of numerous localities was a major impetus behind the drafting of national grain rules. Are the Association's Trade Rules in Danger?, 13 WWGT 28 (Feb 20, 1923-24) ('No buyer can possibly keep up with all the rules and regulations of all the shipping markets of the country. That's why the National rules were formulated."). The sometimes costly efforts that trade associations make to educate their members about the content of rules and customs suggest that even the easily accessible rules are not that widely known. See 11 WWGT 34 (Nov 5, 1921-22) ("There has never been an annual report of an arbitration committee that did not point out the lack of knowledge of the trade rules shown by the rank and file of the members."). Moreover, small merchants are less likely than large transactors to know the content of commercial customs (particularly those outside of their immediate area), in part because custom is learned through observation of, and participation in, transactions and smaller transactors participate in fewer transactions. See, for example, NHA, Report of the Twenty-Eighth Annual Convention 86 (1921) (defending the retention of a written rule on reshipment, on the grounds that "the small country shipper is usually not well posted on rules and customs and the association should very carefully guard his interests. The man of broader experience is usually well informed and is entirely capable of looking after his own interest but not so with the smaller shipper who innocently trusts his business to a market").

Second, transactors are likely to find it undesirable, and perhaps difficult, to persuade others to do business on terms that radically depart from custom or commercial standards. Because transactors who propose to transact on explicitly noncustomary terms are likely to be viewed with suspicion, their proposals are likely to be met with counter proposals, so the relational costs of even proposing a departure from custom might be high and the associated risk of transaction breakdown significant. See Lisa Bernstein, Social Norms and Default Rules Analysis, 3 S Cal Interdise L J 59, 69-73 (1994). 
must negate them with specificity, ${ }^{193}$ something that by assumption is not possible.

\section{Conclusion}

In sum, the incorporation strategy is based on an overly broad conception of the types and geographical scope of customs that consistently exist in merchant communities. However, even if one believes that some customs do exist, support for the incorporation strategy in merchant industries would not necessarily follow. In most merchant industries, transactions are consummated orally and confirmed by sending standard form memoranda with long, back-of-the-page printed recitals. In such contexts, those customary understandings that truly do exist could easily and inexpensively be memorialized in standard form boilerplate. In other words, the number of customs that are clearly enough defined and widely enough known to be true implicit contract provisions, but that are nonetheless not worth including in contractual boilerplate, is likely to be quite small.

Nevertheless, because the concept of custom seems to retain some salience to merchants-who use it variously to describe their own past contracting practices or the loose distribution of contractual behavior in the market as a whole-it is useful to explore in more detail the role played by the notion of commercial custom in merchant relationships.

\section{The Relationship-Creating Role of CUSTOM}

The empirical evidence presented in Part I casts doubt on the systematic existence of industry-wide unwritten customs that are generally known, geographically coextensive with the scope of trade, and implicitly assented to by market transactors. It also substantiates the likely existence of some local customs as well as some relatively common industry-wide practices. More generally, however, the evidence strongly suggests that the types of customs that exist, even in these rather well-defined merchant communities, do not amount to anything close to the all-pervasive sets of implicit gap-filling provisions and dictionary-type interpretive guides assumed by the Code.

Nevertheless, while merchants do not, for the most part, conceive of customs as providing them with legally enforceable contract terms, most merchants evidence a keen interest in learning and talking about the way business is usually done in their industry. One explanation for this interest is that transactors ap-

${ }^{193}$ See note 189. 
proach transactions, particularly those with a stranger, with a rough sense, derived from aggregating behavior over the market as a whole, of the way such deals are usually concluded and performed. ${ }^{194}$ These aggregations (or distributions) of behavior, which might be termed weak-form customs, play an important role in the development of commercial relationships. This role can best be understood by drawing on the insights produced by basic signaling models and by recognizing that many merchant-tomerchant commercial transactions have features that can best be captured by the intuitions underlying repeat-play prisoners' dilemma models, ${ }^{195}$ in which cooperation is best established and maintained when transactors follow any of a number of tit-for-tat strategies. ${ }^{196}$ These strategies dictate responding to cooperation with cooperation and defection (or a series of defections) with defection for a defined period of time followed by a return to cooperation.

One of the main barriers to both establishing and maintaining commercial cooperation is that it may be difficult for a transactor to determine, by simply observing actual outcomes, whether the other transactor has defected. Making this determination is a difficult and error-prone process, particularly in merchant industries where the commodity being sold passes through many hands ${ }^{197}$ and the quality of the good is so strongly affected by climatic, storage, and transportation conditions that even after optimal precautions have been taken, a significant probability remains that performance will not be exactly as promised. ${ }^{198}$ Each

194 Alternatively, the customs and commercial standards incorporated by the Code may actually be important sources of contractual understanding for smaller merchants who engage in mostly local trade.

${ }^{15}$ For an overview of these signaling models that explores their application to numerous legal issues, see Eric A. Posner, Law, Cooperation and Rational Choice (1998) (unpublished manuscript on file with U Chi L Rev). The discussion here differs slightly from Posner's in that the costiy action that constitutes the signal sent by the seller is not a deadweight loss (in the way that burning money, which would also send the requisite signal, would be a deadweight loss) because the high quality delivery will benefit the buyer.

${ }^{10}$ See Avinash K. Dixit and Barry J. Nalebuff, Thinking Strategically: The Competitive Edge in Business, Politics, and Everyday Life 113-15 (W.W. Norton 1991) (discussing a variety of tit-for-tat strategies).

${ }^{137}$ For example, a bale of cotton may pass though the hands of a farmer, a grain elevator operator, a country merchant, a city merchant, a warehouseman, another city merchant or broker, a transport company (railroad, truck, or barge), and a mill. See generally Bernstein, Private Commercial Law (cited in note 13).

${ }^{198}$ See, for example, Gordon, A Century of Agricultural Abundance at 49 (cited in note 56) ("Each step in the marketing chain [of grain] involves commitments and contracts between two or more parties. The vagaries of weather and transportation congestion and delays can add further disruptions. From the simplest grain purchase contract with farmers to complex, multi-layered string trades, there is an inherent opportunity for misinterpretation of a contract term or condition or nonperformance."); NHA, Report of the Fourth 
time a transactor mistakenly classifies an outcome as defection, the likelihood that she will respond by defecting now or in the future increases, making relationship breakdown more likely. ${ }^{199}$

In order to understand the role played by these weak-form customs, consider a seller (S) who is dealing with a buyer (B) for the first time in a market where repeat-dealing relationships, once established, have an economic advantage over discrete transactions, perhaps because they reduce cooperation and performance costs as the transactors learn about one another's expectations and business operations. ${ }^{200}$ Suppose further that at the outset of the relationship B knows nothing about $\mathrm{S}$. In such a situation, $B$ will assume that if $S$ is trustworthy (that is, if he is a cooperator) he will perform within customary bounds on all aspects of the deal, and that if he is not trustworthy (that is, if he is a defector) his performance will fall outside these bounds. The contract takes this into account through the price term. $B$ is willing to pay a price corresponding to the customary ranges of performance on all aspects of the contract, weighted by the probability of their occurrence. These customary ranges roughly, though imperfectly, reflect the aggregate performances of all

Annual Meeting 23 (1897) ("[A] shipper may in perfect honesty consign a car of hay to the receiver under the impression that it is No. 1 hay, and if it proves to be No. 2 hay, that is not conclusive evidence that the shipper is dishonest.").

${ }^{199}$ Where two transactors are playing a "pure" tit-for-tat strategy, a single act that is misinterpreted by Transactor 2 as defection will lead him to defect in response. This will, in turn, lead Transactor 1 to defect, and cooperation will disintegrate. In real-world interactions, however, because a "pure" tit-for-tat strategy is so sensitive to breakdown, game theory suggests that a more successful strategy would be a modified, more "forgiving" titfor-tat strategy that does not dictate responding to every bad outcome (that is every real or suspected defection) by inflicting a punishment. See Dixit and Nalebuff, Thinking Strategically at 113 (cited in note 196). These relatively forgiving strategies, such as tit-for-two tats, are commonly followed by merchants. See Bernstein, Private Commercial Law at 5759 (cited in note 13) (noting that a strategy of negotiating forgiving adjustments until a relationship is terminated is common in transactions between cotton merchants and cotton mills; and noting that a strategy of ignoring defections or making forgiving adjustments in response to a certain number of defections and responding to defections thereafter with punishment of a limited variety, such as refusing to deal for a specified period, and then returning to cooperation is commonly followed in transactions among merchant members of the Memphis Cotton Exchange).

${ }^{200}$ For example, as $\mathrm{S}$ learns about B's business, he can more accurately assess when slightly nonconforming tender will or will not disrupt the buyer's business (if tendered with a price adjustment) and can adjust his precaution investment accordingly. As one Texas Feed Dealer explained, "I prefer to deal with old customers since when I ship, I know that the goods will be suitable and will therefore be accepted even if they are not exactly to contract." Interview with Texas Feed Dealer (1999) (on file with author). Similarly, in the cotton industry, where mills and merchants have been unable to agree on rules regarding the unloading of truck shipments-particularly, the hours receiving stations must operate, the order in which arriving trucks will be unloaded and graded, etc.knowing the practices of the mill he is selling to is very important to the merchant. See Bernstein, Private Commercial Law (cited in note 13). 
transactors in the market and are largely common knowledge to both buyers and sellers. ${ }^{201}$ Suppose, for example, that quality is the key term in a wheat contract. If the contract calls for No. 3 Wheat, the weak-form customary range would correspond to how often in the market, when a contract calls for No. 3 Wheat, No. 3 exactly is delivered, how often something better than No. 3 is delivered, and how often something worse than No. 3 is delivered. ${ }^{202}$

Returning again to B and S. If S's performance is within the customary range, $B$ will conclude that $S$ is a cooperator and will enter into another deal. This will continue as long as S's performance is within the customary range and, over time, a pattern of S's performance being closer than customary to the desired performance emerges. In these early stages of the emergent contractual relationship, $\mathrm{S}$ may be taking a loss on each contract. $\mathrm{He}$ is taking the level of precaution associated with delivering close to the promised performance, but is only receiving the price associated with customary ranges of performance. However, S's willingness to take this initial loss adds value to the relationship. ${ }^{203}$ It is a credible signal to $B$ that $S$ has a low discount rate-that is, that he plans to continue to cooperate with B in the future. Over time, if S's performance is closer than average to the desired performance, here the promised quality, B will see this course of

${ }^{201}$ Although these aggregations of practices are unlikely to supply the optimal performance ranges for any particular pair of transactors, aggregating as they do over transactions that likely differed greatly in both purpose and scope, they may nonetheless be valuable in these early rounds precisely because they are common knowledge. The element of value created by the fact that they are common knowledge may outweigh their lack of a tailored fit with the specifications and error ranges the transactors really desire. $B$ and $S$ should be equally able to observe aggregate market behavior so weak-form customs should be fairly good cooperation initiators. But see note 223 and accompanying text.

${ }^{202}$ Transactors seem to instinctively use these types of ranges to assess whether the other transactor intended to cooperate or defect. See, for example, Secretary's Book at 8081 (cited in note 59) ("Most dealers state on their card bids that grain missing grade will be taken at market difference on day of arrival, and I believe that a fair interpretation of this term means that the seller who accepts it must deliver grain of the grade he agrees to, or some so near it in quality that he may reasonably expect it to grade. If a person sets up a target, turns his back to it and shoots in the opposite direction, it cannot be reasonably said that he misses the target, and it is equally true that if a person sells No. 2 yellow corn and delivers corn which inspects No. 4 or no grade, it cannot be reasonably said that the corn missed grade. This may seem an exaggerated illustration, but it explains the point.").

${ }^{200}$ Alternatively, S may take the customary level of precaution and deliver only within the customary range, thereby not incurring any loss in the initial rounds. In these early rounds, the transactors will still learn about one another's operations, giving rise to switching costs, which may facilitate the creation of a repeat-dealing relationship. However, this method of establishing a relationship is less likely to succeed than the method discussed into the text, since S's behavior in earlier rounds conveys less information about his likely future behavior to $\mathrm{B}$. 
dealing ("CD") emerge. Gradually, she will come to pay S a higher price to reflect this better performance. ${ }^{204}$

Despite the loss he suffers in early rounds, $\mathrm{S}$ has confidence that, once a repeat-dealing relationship is established, B will want to remain in it and will therefore let $S$ slowly recoup his initial investment. ${ }^{205}$ S's confidence that $B$ will behave this way is rational because the early rounds of any contracting relationship are costly to $B$ even though she is paying only the customary price and may, in fact, be receiving higher than customary quality. Because quality is important to $B$, during these initial transactions she may have to deal with multiple suppliers to ensure that she will have the requisite amount of a particular quality of the commodity on hand. Alternatively, she may have to keep sufficient inventory on hand to cover her needs in case the new $\mathrm{S}$ delivers towards the low end of the customary range.

The information transactors learn about one another's businesses in these early dealings gradually reduces the coordination and performance costs of dealing with one another, ${ }^{206}$ giving rise to switching costs for both B and S. Once the relationship is established, both transactors therefore have a reason to want to maintain it. ${ }^{207}$

\footnotetext{
${ }^{204}$ During these early rounds of the transactional relationship, the weak-form custom also provides benefits to $S$. In its absence, and in the absence of any other agreed range, $S$ would take even more precautions to ensure that performance was exactly as promised, fearfil that $B$ would interpret any deviation as breach that would trigger a retaliatory response. However, in addition to giving $B$ a way to ascertain that the deviation was unlikely to be a defection, the custom also constrains her behavior. When $B$ rejects goods that are within customarily acceptable ranges, $S$ can threaten to impose multilateral reputational sanctions-publicizing B's action to market transactors who would likely agree that B's action was improper. Indeed in the cotton industry, mills that acquire a reputation for being very inflexible on quality deviations find that they have to pay more for goods than do mills with a reputation for flexibility. See, for example, Interview with Cotton Merchant (date unavailable) (on file with author) ("Mills get a reputation about how flexible they are when certain circumstances arise [and] a merchant considers this very valuable business knowledge, this information about how flexible a mill will be. Some mills are more stringent about adjustments, and are very strict about demanding exact conformity to the contract. These mills have to pay more for cotton than mills who are willing to be more flexible. The market knows."). Conversely, when B accepts goods in the customary range even though they are not exactly what she wants, $S$ is not going to interpret this as acquiescence that lower quality delivery is "acceptable." However, the Code provisions that permit contract modification by course of dealing or course of performance endorse just such an interpretation of the action.

${ }^{205}$ This initial sacrifice by $\mathrm{S}$ can be thought of simply as a relationship-specific investment that will be amortized over time.

${ }^{200}$ See note 200.

${ }^{20}$ Alternatively, even in the absence of either weak-form custom or good reputation information, cooperation could emerge if a buyer and seller had a common view of the distribution of outcomes (where an outcome is an actual completed aspect of the promised performance) after an agreed-upon level of precaution had been taken. In such a situation,
} 
Once B and S establish a relationship-specific CD zone, and the contract price adjusts both to reflect it and to permit $S$ to recoup his initial investment, if S's performance is within this zone it will be considered cooperation, and if it is outside this zone, or outside of the zone on several occasions, it will be considered defection. At this stage of B and S's contracting relationship there are two kinds of defection: defection that is outside the CD zone but within customary range and defection that is outside even the customary range.

Defection that is outside the private CD zone but within the customary range may, if it is a nonregular occurrence, call for a price adjustment on the next deal, or some other measured response such as not dealing for a few rounds. Although the CD zone is narrower than the customary range, making more outcomes defection, a CD relationship is actually less vulnerable to breakdown than a customary one. Because transactors in a CD relationship are relatively well-informed about one another's operations, they can more accurately infer whether the other cooperated or defected than can transactors in the early and customary stage of their relationship. As a consequence, transactors' responses to outcomes just outside of a well-established CD zone are more tempered. This intuition is reflected in the grain poem "If I Knew You and You Knew Me":

If I knew you and you knew me

'Tis seldom we would disagree;

But never having yet clasped hands,

Both often fail to understand

That each intends to do what's right

And treat each other "honor bright."

How little to complain there'd be

If I knew you and you knew me.

outcomes within the agreed zone of error, or perhaps within two standard deviations of its mean, would be considered cooperation. Outcomes outside the zone, or repeated outcomes outside the zone, would be considered defection. More specifically, if transactors had a common understanding of the error ranges associated with each aspect of performance after optimal precautions had been taken, if the Code were to define customary ranges in terms of these random errors, and if courts too could make these determinations with reasonable accuracy at reasonable cost, enforcing this "custom" as a term of the contract would be value creating. It might remove the incentive for $S$ to engage in too high a level of precaution early in the relationship when a random but large deviation is most costly to the relationship (either because the relationship-specific background to assess it has not yet developed, or because it is one of a fewer number of data points on behavior and so will have larger influence on the transactors' assessments of one another's behavior than would a later deviation) and will effectively constrain opportunism by both $B$ and $S$. In such a regime, $S$ might try to be opportunistic by consistently delivering to the low end of the range, but if he did so $B$ could terminate the relationship. 
When'er we ship you by mistake,

Or in your bill some error make,

From irritation you'd be free

If I knew you and you knew me.

Or when the checks don't come on time

And customers send nary a line,

We'd wait without anxiety,

If I knew you and you knew me. ${ }^{208}$

In most industries, merchant transactors' responses to particular breaches do depend strongly on the identity of and their prior relationship with the breaching party. ${ }^{209}$

In contrast, defection outside the customary range, such as either a delivery or a series of deliveries outside the customary range, is likely to signal defection and to trigger an endgame round-that is, termination or suspension of the relationship and a resort to arbitration to recover money damages. ${ }^{210}$ Moreover, be-

${ }^{208} 12$ WWGT 35 (June 20, 1922-23).

${ }^{200}$ NHA, Report of the Twenty-Seventh Annual Convention 55 (1920) ("We have noted instances of where a shipper would invoice a car as being No. 2 timothy, when as a matter of fact there might be some 'off' grade hay. However, the receiver knowing the shipper and of the conditions under which the hay was bought and loaded, knew that there would be no trouble over the invoicing as he knew the shipper was not trying to slip something over on him. Hence the value of personal relationship between buyer and seller. In other instances this practice causes a lot of trouble."). See also email from participant in the Cotton-L List Serve (One cotton transactor explained that if a transactor asks to be released from a contract "you have to look at the circumstances for not providing the cotton (no prices going from 70 to 80 is not acceptable). A disaster is a disaster. Who you are dealing with is also important, for both sides. Have you been selling your cotton to this guy for 10 years.") (email on file with author).

${ }^{210}$ Although it is difficult to establish whether or not a dispute is an endgame dispute, in part because even if two agents never deal again, their companies might still choose to do so, there is nonetheless evidence that in some merchant tribunals most cases are endgame disputes. For example, between 1975 and 1996, 54 percent of the cases heard by the Board of Appeals, the tribunal that resolves disputes between cotton merchants and cotton mills, were absolute endgame disputes. The most common triggers of the endgame were the insolvency or financial distress of a party or the closing of a cotton office, and the second most common were a change of control of one of the entities involved or the retirement of a person directly involved in the transaction, both events that upset settled expectations. Another 18 percent of the cases involved disputes that might fairly be classified as endgame. They involved the effects of a government subsidy program that made large sums turn on who had possession of cotton on a particular day. These cases were ones in which an event took the contract out of the self-enforcing range and made it worthwhile for one of the parties to end their contracting relationship. The remaining 27 percent of the cases involved primarily factual disputes about late payment and late delivery. Transactors explained that if they had to take a case to the Board of Appeals they would be quite unlikely to deal with the other party again. Bernstein, Private Commercial Law at 46-47 (cited in note 13). See also NHA, Report of the Twenty-Fifh Annual Convention 126 (1918) (stating that the arbitration report notes that "once a case is brought to the attention of the Arbitration Committee, the parties concerned will no longer have the confidence in each other. Their difference begets contradiction, contradiction begets heat, and heat rises into rage and ill-will. Then all human judgment is laid aside and men no longer 
cause most market participants know the loose contours of the customary range, defections outside of it can also be sanctioned through multilateral reputational sanctions. These sanctions are only available when a significant number of market transactors agree that an outcome, or a series of outcomes, is defection and when the defection or defections are either observable to many market participants or can be credibly revealed to them at a reasonable cost by the breached-against party. ${ }^{211}$

As each transactor comes to know the other's business and switching costs increase, making defection more costly, the CD zone becomes increasingly stable and the weak-form customs that initially provided useful relationship-creating norms diminish in importance. Once this occurs, the transactors can begin to develop value-creating, relationship-specific, relationship-preserving norms ("RPNs") that may (or may not) depart from industry practice, the transactors' written contracts, and, in the trade association context, the default provisions supplied by trade rules.

Sometimes these RPNs may be explicit extralegal agreements that contradict the contract's terms. An example is an agreement not to demand the federally supervised weights required by most feed contracts, but instead to rely on one another's in-house weights, typically splitting any differences that may arise until opportunism is suspected and one transactor reverts to demanding compliance with the contract. ${ }^{212}$ In a similar vein, one lumber dealer explained:

Of course, we all know that many small adjustments are made every day, where allowances asked are not unreasonable and where the salesman can verify the customers contention, but when it looks as the 'something was being slipped over' or where the mill will not agree to any allowance, THEN IS THE TIME TO DEMAND OFFICIAL INSPECTION ACCORDING TO THE TERMS under which THE LUMBER WAS SOLD. ${ }^{213}$

consider their business transactions as sacred").

${ }^{211}$ Although the sanction for a breach that falls outside of the customary range is larger than it would be in a world with no rough consensus as to the parameters of the range, it is not clear that deterrence will necessarily be too high. In the repeat-play context, this hybrid legal and reputational sanction is not usually imposed for any one deviation but rather for several. It is therefore likely to be imposed less often and more accurately than the standard monetary remedy for breach.

212 See Bernstein, $144 \mathrm{U} \mathrm{Pa}$ L Rev at 1793 n 96 (cited in note 13).

${ }^{213}$ PCSA, The Secretary's Weekly Letter No 43 (Oct 4, 1911). See also Fagg \& Taylor v S.F. Scattergood \& Co (NGFA 1912), reprinted in Decisions of the Arbitration and Appeals Committees at 74-75 (cited in note 49) (in a case where the acceptability of particular routing was at issue, the defendant "acknowledges that he has used [that is, accepted] this 
Other times, RPNs may be variants of the contract's explicit provisions that add flexibility by defining acceptable ranges of performance. Alternatively, RPNs may recast the contract's explicit provisions, which may condition on information that is verifiable but not observable, ${ }^{214}$ into extralegal understandings that impose approximately the same obligations but condition only on information that is observable to both transactors.

In repeat-play contracting relationships in particular, provisions that condition only on information that is either observable or both observable and verifiable are more likely to successfully maintain cooperation than provisions that condition on information that is verifiable but not observable. When transactors bargain in the shadow of information that is only verifiable, in the absence of the requirement of full disclosure required by the discovery rules, it is often difficult-if not either impossible or prohibitively costly-for transactors to credibly reveal to one another the information necessary for a cooperative adjustment to be reached. It may therefore be difficult for transactors to recognize the parameters of the zone of agreement, thereby increasing the risk of cooperative breakdown. Although most of the economics literature discusses information that is observable but not verifiable, or information that is both observable and verifiable, in legal settings one of the most important types of information is information that is verifiable but not observable. The rules of civil discovery would make no sense if this latter category were not of primary importance in defining legal relations and deciding cases.

Consider, for example, a contract provision calling for the payment of fully compensatory expectation damages in the event of breach. Suppose that $S$ inadvertently breaches the contract and, in a cooperative vein, immediately offers to pay $B$ full expectation damages. In many contexts, to make $B$ truly whole this measure would have to include lost profits, which must be calculated by reference to both expected revenue and expected costs. While $B$ might be able to credibly reveal his expected revenues, perhaps by showing $\mathrm{S}$ written orders he will be unable to fill, $\mathrm{B}$ cannot credibly reveal his costs. The lower B's alleged costs, the

routing on similar contracts, but states that he only did so because it did not cause him loss or inconvenience, and further that it is their custom to ignore breaches of the contract where they are not inconvenienced," explaining that they "seldom pay any attention to technicalities ... [that] do not cost us anything ... but where a shipper does not fulfill his contract and the amount involved is sufficient to warrant our insisting upon a shipper fulfilling a contract we do not feel we should be called technical").

${ }^{214}$ See notes 184 (defining observable) and 185 (defining verifiable). 
greater his recoverable damages. $\mathrm{S}$ therefore has no reason to believe that $B$ has accurately revealed all of his costs. ${ }^{215}$ In the absence of even the weak threat of discovery sanctions for incomplete information revelation, B's revelations will not be credible. This uncertainty may give rise to suspicion and may lead the parties to have different views of the settlement zone. In contrast, had the contract called for damages in the amount of the difference between the contract and the market price, the zone of agreement would be clear and, because the breach was inadvertent, cooperation would more likely be restored.

More generally, because most efficient customary norms and the relationship-specific RPNs that give rise to them will not condition on information that is only verifiable, and may condition on information that is observable but not verifiable, customary norms are unlikely to be the optimal rules for a tribunal to apply in the event of a dispute. And, if transactors knew, as they would if their contract were governed by the Code, that any relationship-specific RPN followed more than once may be transformed into a legally enforceable obligation in the event of a dispute, they would be far less willing to diverge from the terms of their written agreement, even in situations where doing so is highly beneficial to one transactor and costless to the other.

Understanding these and other reasons ${ }^{216}$ why the optimal norms to govern a relationship are likely to differ at different

\footnotetext{
${ }^{215}$ These costs may also be very complicated to prorate to a specific contract. Moreover, $B$ may hesitate to reveal them since the next time $B$ and $S$ negotiate a deal, $S$ will be able to more accurately assess B's reservation price.

${ }^{216}$ For example, in markets where most transactions are between transactors with long-term, repeat-dealing relationships with one another, if those customary RPNs that do exist emerge from pair-wise sets of transactors choosing independently to follow them as parts of established courses of dealing, it is likely that these RPNs will be relatively wellsuited to mature, long-standing transactional relationships but relatively ill-suited to new contractual relationships where trust has not yet been established and the transactors have minimal information about one another's business operations. As a consequence, courts looking to these customary norms to interpret contracts made in early stages of relationships will be imposing obligations the transactors did not, and would not, have voluntarily assumed. In addition, because it will be easier to prove to a court those prior instances where a practice was followed than it will be to prove that a precondition failed to occur so a practice was not followed, court interpretations of custom are likely to leave out important preconditions. Perhaps the most important such precondition is the degree of trust (defined here to mean a transactor's perception of the likelihood that the other transactor will act opportunistically if unconstrained by a legal or nonlegal sanction) the transactors have in one another. The types of norms one would agree to be governed by if dealing with an angel are quite different from the types of norms one would agree to be governed by if dealing with a scoundrel; yet the ability of courts to distinguish between angels and scoundrels is, on the margin, quite limited.

For a discussion of additional reasons why one would expect both actual and optimal relationship-preserving customary norms to differ from optimal legally enforceable con-
} 
stages of a contracting relationship, and recognizing that relationship-creating and relationship-preserving norms are likely to differ in content and structure from the optimal endgame norms for a tribunal to apply in the event of a dispute, makes it easier to understand why merchants do not want either their relationshipspecific courses of performance and courses of dealing ${ }^{217}$ or their every-day customary practices-like granting price adjustments for nonconforming tender-incorporated or written into the law. ${ }^{218}$

It is, however, difficult to empirically verify that weak-form customs are in fact useful relationship-creating norms and are being used to initiate repeat-dealing relationships. Nevertheless, as demonstrated earlier, transactors attach a great deal of importance to their prior dealings with a transactor in deciding how to respond to different situations that may arise, ${ }^{219}$ and there is some evidence that transactors view the early stages of a relationship as a time to learn about one another's reputation, reliability, and business practices. ${ }^{220}$ In the cotton industry, for ex-

tract provisions, see Bernstein, $144 \mathrm{UPa} \mathrm{L}$ Rev at 1796-1815 (cited in note 13).

${ }^{217}$ For example, the Trading Rules of the National Cottonseed Products Association, Inc ("NCPA") prohibit arbitrators from enforcing "terms or conditions not expressly provided for in these Rules," except where such variant terms are explicitly permitted by the rules. NCPA Rules Rule 1 at 34 (NCPA 1994-95). See also Interview with Association Executive (July 1996) (on file with author). This approach is also adopted by the American Spice Trade Association, whose arbitration board excludes contextual considerations and only hears cases based on breach of unmodified association-drafted standard form contracts. Interview with Association Executive (June 1996) (on file with author). Similarly, preliminary research suggests that arbitrators at the Green Coffee Association of New York are strictly unwilling to look to course of performance or unwritten custom of trade. Interview with Arbitrator (Apr 16, 1998) (conducted by Drew Porter, on file with author) (noting they do not look to custom); Interview with Arbitrator (Apr 15, 1998) (conducted by Drew Porter, on file with author) (noting that arbitrators don't look to conduct in interpreting a contract and stating that any variation from the contract would be subject to approval by both parties, and any decision to depart from the contract would require some sort of written proof for arbitrators to take it seriously); Interview with Arbitrators (Apr 14, 1998) (conducted by Drew Porter, on file with author) (telling the interviewer there are no unwritten customs). The Association of Food Industries, however, has adopted a slightly less formalistic approach. If a contract is silent, arbitrators look to custom and will give contractual language its ordinary meaning in the trade. However, they do not permit custom to override explicit contractual provisions and will not take courses of performance or courses of dealing at odds with contractual language into account in deciding cases. Interview with Arbitrator (Feb 1997) (on file with author).

${ }^{218}$ See note 172 and accompanying text.

${ }^{219}$ See notes 208-09 and accompanying text.

${ }^{220}$ See Heggblade-Marguleas-Tenneco, Inc v Sunshine Biscuit, Inc, 59 Cal App 3d 948, 131 Cal Rptr 183, 185-86 (1976) (recounting seller's statements that it would “overplant 'a little bit' since this would be their first contract and they wanted to be sure they could prodice the quantity needed," and the sellers "have picked our best land ... for we want to be sure to effect the best delivery possible"; also quoting from a letter from the buyer stating that "we would like to start with you on the basis of obtaining 100,000 sacks of 
ample, where mill-buyers consider the reputation of merchantsellers to be very important, most mills consider their own past experience dealing with a merchant to be one of the most important sources of reputation information. ${ }^{221}$ Mill-buyers explain that to learn about reputation they will typically start with a "lower quantity deal with an intermediate price," and then see what happens; "if [the merchants] are bad," or "fuss at them a lot," then they won't deal with the person again. ${ }^{222}$

Caveat. This account of the emergence of repeat-dealing relationships, though plausible, is also subject to empirical challenge. In markets where buyers and sellers play fixed roles in the chain of production and distribution, buyers as a group and sellers as a group sometimes have divergent views about the content of these aggregate market practices. ${ }^{223}$ These divergences may, in fact, be

Kennebec potatoes from your operation .... This arrangement would balance our needs with the opportunity for you to perform directly for us and evaluate our relationship. At the same time, it would enable us to do what we have always done in the past-maintain our loyalty to those who have served us well in the past").

${ }^{221}$ When ten mills were asked how they obtained information about the reputation of merchant-sellers, nine mentioned their own past experience with the merchant as a significant source of information, though, as one noted, this method of obtaining information taught "hard lessons." Mill Questionnaire No 2 (no date available); id ("my own experience"); Mill Questionnaire No 3 (July 28, 1997) ("trade"); Mill Questionnaire No 4 (Aug 6, 1997) ("experience mostly"); Mill Questionnaire No 5 (Aug 8, 1997) ("past experience"); Mill Questionnaire No 6 (July 30, 1997) ("experience"); Mill Questionnaire No 7 (July 31, 1997) ("from prior dealing with him"); Mill Questionnaire No 8 (July 29, 1997) ("personal experience"); Mill Questionnaire No 9 (July 29, 1997) ("By doing business with him."); Mill Questionnaire No 10 (July 28, 1997) (by looking at "our past experience with him"). All Mill Questionnaires are on file with author. Mills explain that they also obtain information about reputation from other sources including gossip, the trade press, and their bankers.

${ }^{22 a}$ Mill Questionnaire No 1 (Oct 7, 1997) (on file with author). Merchants also consider past dealings with a particular mill important to evaluating the mill's reputation, but because there are many fewer mills than merchants, they tend to rely more on the "word on the street," specifically Front Street in Memphis, for their information. Yet they too rely on their own experience to assess reputation; but as one warned, "if you have never dealt with the other party before, deal in small quantities." Interview with Merchant (no date available) (on file with author).

${ }^{225}$ See, for example, Bureau of Trade Relations, National Retail Dry Goods Association ("NRDGA") and SAA, Survey of Trade Practices in the Silk Trade 10 (NRDGA \& SAA 1944) ("Retailers report that the average length of time usually consumed in making returns is approximately four days although a substantial number of replies indicate that from seven to ten days is the amount of time usually required. . . From the manufacturer's viewpoint, [however,] replies indicate that the usual length of time consumed by the retailer in making returns is seventeen days. ... Both the manufacturers' and retailers' replies to this question [about return times] vary from less than one day to thirty days."). See also Note, 61 Yale $I \mathrm{~J}$ at 702 (cited in note 85) (noting that in the early rayon industry, "trade customs, which are understood and in part written, have not been accepted by both buyers and sellers. ... there is no uniformity").

It is also important to note that in some industries, such as textiles, certain definitions of quality, like "Seconds" and "first quality," are not even defined in market, re- 
wide enough to impede the emergence of repeat-dealing relationships. However, even in the absence of consensus on the customs relating to all or most aspects of a transaction, cooperation may still arise if there is a common view of the practices relating to a few, preferably core, aspects of trade. If the signal sent with respect to these issues is strong enough, transactors will likely be more flexible in dealing with other aspects of trade that contradict their expectations because they will have greater confidence that their transacting partner is not a defector.

Perhaps more importantly, however, many merchant industries, particularly those with private legal systems, are characterized by institutional rules and features, ${ }^{224}$ as well as a variety of contracting practices, that can best be understood as promoting the emergence and endurance of the type of common knowledge that is important to the development of repeat-dealing relationships. The adoption of trade rules might, for example, be understood as an effort to explicitly create this type of common knowledge. ${ }^{225}$ Some of these rules explicitly set out acceptable ranges of contractual performance, ${ }^{226}$ while others provide focal points around which acceptable ranges of outcomes could arise. As one drafter of the 1986 revisions to the WSRs explained, "The rules provide two businessmen a way to settle an argument by getting

gional, or local terms. Rather they are defined in terms of the past output of a particular mill. See Definitions and Trade Customs, WSR 32 (1936).

${ }^{224}$ In some industries, social conditions or past social conditions may also have supported the emergence of commercial relationships, not only by making the fact of defection more observable to market participants through gossip networks that were wellestablished to meet other needs, such as detecting religious deviance, but also through strong interpersonal relationships that transcended business dealings. These types of forces served to increase the reputation bond posted in each transaction and to promote common understanding. In the cotton industry, this function was served by the culture of honor in the Old South and encouraged by groups like the Cotton Wives Club of the Memphis Cotton Exchange. In the diamond industry, it was served by the close-knit nature of Orthodox Jewish Society. See Bernstein, $21 \mathrm{~J}$ Legal Stud at 130 (cited in note 173). In the textile industry, closeness was fostered by geographical proximity, see Textile History at 1 (cited in note 83), and social events, some of which, like the textile follies, a musical lampoon, continue to the present day. See Textile Distributors, 155 Women's Wear Daily No 101 at S 36 (May 24, 1988).

${ }^{225}$ Interestingly, codified local customs can also promote cooperation even between transactors in different locations with conflicting codified customs. Suppose that S promises to deliver lumber "promptly" and does so within ten days. If "prompt" in the B's locality means five days, he might classify the delivery as defection if the term is not defined either orally or in the contract. If, however, $B$ makes his objection and the reason for it known to $\mathrm{S}$, and $\mathrm{S}$ shows him a Trade Rule from her locality defining prompt as twelve days, B will likely classify S's action as cooperation and simply negotiate a more specific clause in the future, rather than treat the delay as defection and terminate the relationship. If, however, the twelve day practice were unwritten, S's claim would be far less plausible and relationship breakdown would more likely follow.

${ }^{228}$ See note 187. 
insight into what other businessmen think is standard."227 Today, some trade rules have themselves come to be considered the customs of the trade. ${ }^{228}$

Moreover, association-sponsored educational efforts to promote knowledge of both trade rules and the content of work-a-day business practices were far reaching, and even today the cotton industry sponsors an introductory nine week course at Rhodes College that includes instruction in "the ethical implications of contracts, contract law, and the importance of contract sanctity; ... typical trade terms and conditions in the various markets; ... [and] international trading rules."229 Similarly, the NGFA sponsors trade rules seminars in which participants study the trade rules, read arbitration opinions, work through hypothetical trading situations, and listen to speeches about trade ethics and proper trading practices. ${ }^{230}$ In most industries these efforts are and were complemented by extraordinarily active trade presses.

The opinions issued by merchant arbitrators also serve to promote common knowledge. Although no merchant-run arbitration tribunals give formal precedential weight to their prior decisions, the tribunals discussed here, along with many others, nonetheless produced, published, and widely disseminated arbitration opinions. Although these opinions served a variety of functions, ${ }^{231}$ perhaps the most important was to educate members 84).

${ }^{277}$ Palmieri, Lawyers Group Publishes Revision, 16 Daily News Rec at 9 (cited in note

${ }^{225}$ See text accompanying note 102 (noting that the WSRs have become custom); Arbitration Practice Upheld, 3 Silkworm 137-38 (July 1921) (noting that "practically all raw silk is sold under and pursuant to these rules, so that they have come to bear the dignity of a trade custom").

${ }^{20}$ Rhodes College Web Site, <http:/www.meeman.rhodes.edu/institutes/cotton. curriculum.html (visited Apr 22, 1999).

${ }^{200}$ Similar seminars are run by the Texas Grain and Feed Association. See Nuts and Bolts of the Grain Trade (flyer describing seminar on contracts, trade rules, customs, and arbitration, including panel on "Customs of Trade," "Contract Law," "Arbitration," and "Trade Rules"). See also Trade Rules as Amended at Des Moines Meeting, 13 WWGT 26 (Nov 20,1923-24) (' $[F]$ rom the standpoint of education it can with truth be said that the annual trade rules article is about as valuable a contribution as could be made to the members through their official organ.").

${ }^{231}$ Opinions were viewed as a way of improving the quality of arbitral decisions by forcing arbitrators to articulate reasons for their award. They were also a useful, albeit imperfect, check on certain types of arbitral bias. An arbitrator who signed his name to a widely circulated opinion that was perceived to be biased risked reputational harm and damage to his own business. In addition, especially in the early days, the production of well-reasoned opinions was one of the ways that the association-run tribunals attempted to establish their own legitimacy. In industries that published the names of the disputing parties in the opinions, the prospect that an opinion would be written was a way of encouraging settlement. Opinions often noted that even the prevailing party acted improperly, Cook Industries v Tripple "F" Feeds, NGFA App Case No 1532 (1977) (affirming the primary arbitration panel's judgment against the defendant while noting that the "Arbi- 
of the trade about the content of the rules and the contours of proper business practices, ${ }^{232}$ a function that is still regarded as important today. ${ }^{233}$ The interpretation and discussion of these opinions in the industry-sponsored trade press furthered and continues to further this norm-inculcation effort.

The membership rules of these associations also facilitate this method of establishing relationships. Most associations have substantial membership fees ${ }^{234}$ and strict membership requirements, permitting just a few dissenting votes to block a candidate's admission. ${ }^{235}$ As a consequence, a transactor who behaved

tration Appeals Committee observes regretfully that both parties to this transaction left much to be desired in preparation and performance of the contract ${ }^{n}$ ), thereby giving both parties a reason to settle. See NHA, Report of the Second Annual Meeting 16 (1895) (suggesting that because the Kansas City Hay Association has its opinions "published in the press ... the result has been that today we do not have any complaints in Kansas City between shippers and receivers").

${ }^{202}$ See, for example, the excerpt from the report of C.F. Kraemer, Chairman of the NAWLA Arbitration Committee, in Convention "Highlights", 3 Service 1 (May 26, 1930) (NAWLA arbitration opinions help "to avoid repetition of disputes through the more careful handling of situations likely to develop into controversies. . . we all profit by our mistakes of the past and when it is pointed out to us where we have erred either by neglecting to fully protect ourselves in the original contract or through some oversight and careless attention to conditions arising subsequent to the contract, we can certainly be careful to guard against repetition. That, we conceive, to be one of the important functions of Arbitration."). See also SAA, Fifty-Fifth Annual Report 35 (1926-27) ("Arbitration has been helpful .... It has been found to clarify, in the thought of the trade, the ethics of a situation; and has also, to a certain degree, taught the application of official trade practices as compiled by the several Association divisions.").

Although merchant arbitrators tended to decide the cases strictly on the basis of Trade Rules and written contracts, in many industries their opinions sometimes note that the prevailing party nonetheless engaged in unacceptable business practices. See, for example, Bernstein, $144 \mathrm{U} \mathrm{Pa} \mathrm{L}$ Rev at 1775-76, 1818-19 (cited in note 13). In addition, while none of the trade rules studied imposed a general duty of good faith and fair dealing, and it was quite rare for arbitrators to take good faith into account, see Bernstein, Private Commercial Law at $10 \mathrm{n} 42$ (cited in note 13) (reporting that at the Memphis Cotton Exchange only three of the opinions written from 1944-90 mentioned good faith), opinions sometimes noted that one party (sometimes even the prevailing party) or both parties acted in bad faith.

${ }^{23}$ The NGFA, for example, whose contemporary opinions are among the most detailed and comprehensive published, takes the position that

most importantly, the [arbitration] decisions serve as an educational tool for the industry by communicating how particular disputes have been resolved. While arbitration decisions are not formal precedent as to subsequent disputes, they are especially instructive to the membership because arbitration cases often involve issues faced by others on a daily basis.

Gordon, A Century of Agricultural Abundance at 57 (cited in note 56).

${ }^{24}$ See, for example, Interview with Southern Cotton Association Executive (1996) (noting that dues and fees can, depending on the size of the firm, be well over $\$ 10,000$ per year).

${ }^{235}$ Southern Cotton Association, By-Laws \& Trade Rules Art 2, \$\$ 1-2 (requiring that membership candidates be nominated by five members of the association, that all members be given opportunity to object, that two-thirds approval of the Committee on Mem- 
badly in previous deals with an association member is unlikely to be admitted. In addition, by joining an association, a transactor implicitly binds himself to make more aspects of his commercial behavior observable to market participants. For example, most associations require members to arbitrate all disputes with other members in the association's own tribunals and have a variety of ways of making the outcomes of cases quickly known to association members. Moreover, members who either refuse to arbitrate or who do not comply with an award are usually either suspended or expelled from the association and will typically have their names posted on the exchange floor ${ }^{236}$ and/or mentioned in the association's newsletter along with a description of their wrongdoing. ${ }^{237}$ In most industries these sanctions are severe. Transactors are quite reluctant to deal with someone who has been expelled from an industry association, so these sanctions sometimes put the offending transactor entirely out of business. ${ }^{238}$ The existence of these rules and procedures turns membership into a credible signal that a transactor has a low discount rate since seeking membership, and thereby opening up his future dealings to more exacting scrutiny, would be irrational if he did not.

Finally, contracting practices both in merchant industries governed by private legal systems as well as in those governed by the Code might also play a role in enhancing cooperation. Buyers' and sellers' confirmations often include terms not found in the others' confirmations. These additional terms are often unenforceable under the Code ${ }^{239}$ and may not be enforceable under many industries' approaches to the "battle of the forms." The standard explanation for these terms is that each transactor hopes that the other will either not know the terms are unenforceable or that he will not risk violating them since he does not have the financial resources to defend himself if they are litigated. Yet these additional terms can also be understood as setting the terms that the other transactor must comply with if he wants the contracting relationship to continue. In some indus-

bership be obtained, and that two-thirds of the Board of Directors vote in favor). See also Interview with Association Executive (June 1996) (a few objecting members block admission).

${ }^{258}$ See Bernstein, $21 \mathrm{~J}$ Legal Stud at 138-43 (cited in note 173) (discussing diamond industry nonlegal sanctions).

${ }^{25}$ See, for example, Ten Cases Cleaned Up: Arbitration Committees Decide Six Disputes-Two Are Settled Direct and Two are Expelled, 10 WWGT 39, 40 (Dec 5, 1920-21) (listing the names of those expelled from the association for failure to arbitrate or failure to pay an arbitration award).

${ }^{2 * 3}$ See Bernstein, $21 \mathrm{~J}$ Legal Stud at 141 (cited in note 173).

235 UCC \$ 2-207. 
tries, these terms are supplied not in fine print on contracts, but on posters at the buyer's place of business or in manuals or circulars the buyer produces and distributes to his suppliers. The terms are, in effect, providing a more efficient substitute for common knowledge as to the ranges of practices considered acceptable. These additional terms are really saying to sellers, "It is all well and good for you to comply with the contract, that protects you from suit, but if you want to get repeat business from us, these are the terms you must meet."

\section{Conclusion}

In sum, weak-form customs are neither optimal endgame norms nor, for the most part, optimal RPNs. Rather, they may, under certain conditions, and at certain stages of market development, provide transactors with a set of imperfect, yet nonetheless workable, relationship-creating norms. The availability of these norms-particularly as enhanced by trade rules and other institutional features of trade association-run private legal systems-is particularly important in markets where reputation information is not, standing alone, sufficient either to support exchange between strangers and/or to induce traders to seek the optimal number of transactional partners. More generally, the divergence between the endgame provisions contained in trade rules and written contracts, on the one hand, and the relationship-creating and relationship-preserving norms that transactors follow in their work-a-day interactions, on the other, together with the acontextual approach of most merchant tribunals, enables transactors in many industries governed by merchant-run private legal systems to capture the benefits not only of repeat dealing but also of contracting under a dual set of legally unenforceable relationship-preserving norms and legally enforceable endgame norms, each better adapted to the situations they are designed to govern than either would be to governing the domain of the contracting relationship as a whole. In short, this alternative account of the important role played by weak-form customs in commercial relationships does not depend on courts or other third-party arbiters looking to custom to fill contractual gaps or interpret the meaning of contractual provisions; yet it helps to explain why merchants consider an understanding of customs, at least weak-form commercial customs, to be central to the conduct of successful business operations. 


\section{CONCLUSION}

The goal of this Article has been to raise, though by no means resolve, questions relating to the desirability of the Code's incorporation strategy. It has presented evidence that the Code's conception of widely known commercial standards and usages that are geographically coextensive with the scope of trade does not correspond to merchant reality but rather is a legal fiction whose usefulness and desirability needs to be demonstrated and defended rather than assumed. Although arguments might be developed to justify the use of this legal fiction as a second-best type solution to problems of gap filling and interpretation in commercial law, nothing in the legislative history of the Code, or the scholarly literature on commercial law, has yet put forth an adequate justification for the Code's and the Permanent Editorial Board's broad endorsement of the incorporation strategy.

Indeed, developing a justification for the Code's approach would require separate consideration of the wide variety of ways in which incorporation influences commercial adjudication and, perhaps more importantly, ex ante contracting practices. In addition, given the highly local nature of most customs that do exist, any attempt to rehabilitate the incorporation strategy would have to be accompanied by the development of complex and explicit choice of custom rules. It would also have to take into account the fact that, as a practical matter, the incorporation strategy is closer to the pole of a mandatory, rather than a default, adjudicative approach, and that the consequences of the approach vary widely in its different and varied uses. For example, the Code's use of "commercial standards" in determining whether a contract is definite enough to warrant legal enforcement ${ }^{240}$ might reinforce the undesirable tendency of merchants to underspecify their contracts, a tendency that even today merchant associations actively try to combat. ${ }^{241}$ Conversely, the Code provision specifying that when no time is given for an action to be taken under a contract a "reasonable time" is to be implied ${ }^{242}$ may be less problematic. The cost to transactors of specifying time frames for important aspects of contractual performance in the boilerplate on their confirmations is quite low and might, in fact, be the type of practice

${ }^{2+0}$ Id at $\$ 2-204 \mathrm{cmt}$.

${ }^{21}$ See NGFA, Protecting Your Company's Interest in Agricultural Commodities 13-16, 19,30 (1995) (discussing the importance of entering into well-specified contracts and urging transactors to do so). See also sources cited in note 48 (discussing the tendency of hay dealers to underspecify their contracts).

${ }^{242}$ UCC \& 2-309. 
we want to encourage through a "penalty default" type of incentive. ${ }^{243}$

The battle of the forms situation, in contrast, is one where the Code's incorporation strategy is problematic, especially if the Hayekian view of custom is incorrect and some customs, while not quite rising to the level of customs of adhesion, nevertheless favor certain types of transactors. Under the Code, trade usage is an important consideration in determining whether additional terms in a confirmation "materially alter"244 the offer and are therefore unenforceable or whether they fail to do so and are therefore enforceable unless either the offer limits acceptance to its terms or the inclusion of additional terms amounts to "surprise or hardship." 245 If customs favor the stronger party, but do

\footnotetext{
${ }^{243}$ A penalty default rule is a rule that is deliberately given content that many or a majority of transactors do not like, in an effort to induce them to reveal information and/or to adopt a provision better suited to their transactions. See Iucian Ayre Bebchuk and Steven Shavell, Information and the Scope of Liability for Breach of Contract: The Rule of Hadley v. Baxendale, $7 \mathrm{~J} \mathrm{~L}$ Econ \& Org 284 (1991); Ian Ayres and Robert Gertner, Filling Gaps in Incomplete Contracts: An Economic Theory of Default Rules, 99 Yale L J 87 (1989). If, however, courts then vary the meaning of explicit timing provisions by reference to industry practice, the benefits of inducing explicit contracting might not be attainable under existing doctrine. Although it has been suggested that the incorporation strategy itself might be an effective penalty default, inducing industries that would benefit from a more formalistic adjudicative approach to opt out and create private legal systems, it is important to note that the conditions that make opt out desirable, and the preconditions necessary to overcome collective action problems and make opt out possible, are quite different. As a consequence, industries that might prefer a more formalistic adjudicative approach may not be able to opt out of the Code.

${ }^{24}$ UCC \& 2-207(2)(b) \& cmts 3-5. See, for example, Avedon Engineering, Inc $v$ Seatex, 126 F3d 1279, 1284-85 (10th Cir 1997) (in deciding whether an arbitration provision in an unsigned textile sales confirmation form was a "material alteration" under UCC § 2-207 (which would render it unenforceable), the court looked to see whether the inclusion of an arbitration clause was customary in the trade, explaining that if it was the provision, it would be enforceable); Suzy Phillips Originals, Inc v Coville, Inc, 939 F Supp 1012, 101719 (E D NY 1996) (finding a limitation of liability clause in the seller's confirmation to be "standard trade practice," as evidenced by the WSRs, the court held that it therefore neither materially altered the terms of the offer nor inflicted "unreasonable surprise"), affd, 125 F3d 845 (2d Cir 1997); Graphics v Peck Industries, Inc, 304 SC 101, 403 SE2d 146, 150 (SC App 1991) (same).

${ }^{215}$ UCC $\$ 2-207 \mathrm{cmt} 4$. See also Wilson Fertilizer \& Grain, Inc v ADM Milling Co, 654 NE2d 848, 852-54 (Ind App 1995). In holding that an arbitration provision in buyer's order did not materially alter the offer so as to render the arbitration provision unenforceable, the court explained that the Code's
}

Comments suggest that hardship or surprise may be created by terms that deviate from customary trade standards and practices, but may not be created by terms that operate within the accepted norms of the parties' particular trade. * * [W] hile evidence of usage of trade and course of dealings are not conclusive on the question of surprise ... such proof is significant to the issue. *** In short, a party should not be surprised to find in a confirmation a clause of a type that is customarily used within the trade, whereas the clause is an unreasonable surprise where it represents an unreasonable or harsh deviation from custom. 
not rise to the level of imposing a hardship and are not unconscionable, they will be enforced. This gives large firms, who will also have better resources to hire experts, the ability to get a significant contracting advantage. ${ }^{246}$

Determining the desirability of other Code provisions that rely on incorporation is somewhat more complicated. For example, when the issue is whether usage should be admissible to show acceptable customary ranges of quality, it may be that a penalty-type approach to inducing parties to include more detailed quality specifications in their agreements might work. If, however, it is difficult to describe a quality standard that a nonexpert court will be able to apply, it might be better to encourage transactors to include a quality-determining wiseman provision in their contract. Whether the inclusion of wiseman provisions in appropriate circumstances is more likely to be induced by a default rule that enforces every clause precisely as written, or one that interprets written clauses by customary practices, is just one of many open questions relating to the Code's incorporation strategy that are in need of further exploration.

More generally, it is important to note that one of the primary justifications for looking to custom to fill gaps and interpret contracts is that the customs themselves provide useful information to generalist judges about the intent of the parties, or failing that, about a range of practices whose widespread use suggests that they are viewed as reasonable by industry transactors. However, recognizing that the customs often evolve to govern situations where transactors trust one another and want to continue dealing, but that cases arise when the very trust that makes the custom workable has broken down, suggests that there is no reason to suppose that customs will provide useful information about what contracting parties would have agreed to had they included a provision stating how the matter at issue was to be dealt with if third-party adjudication were required. In addition, because so many customs have an implied precondition that the transactors trust one another, and because many customs condition on this and other information that is inexpensively observable, but that may be quite expensive to verify (that is, to prove to a court with reasonable accuracy), even customs that are widely followed may

\footnotetext{
Id (citations omitted).

${ }^{2+6}$ This suggests another reason that transactors routinely keep clearly unenforceable boilerplate in their contracts. Under the Code, these terms may be unenforceable today but they may also ripen into a custom if they are used by other firms with sufficient frequency over a long enough period of time.
} 
be poor candidates for judicial enforcement. First, from an ex ante perspective, transactors are unlikely to want to spend an infinite amount of money establishing their case if a dispute arises. And second, third-party application of these types of customs may well be error prone. Transactors may therefore prefer a third party to apply a very different rule, one that may be less welltailored to their relationship, but easier and less costly to dispute under should a problem arise.

In sum, while the fact that the Code is built on a highly questionable empirical basis does not necessarily mean that its drafters erred, it does mean that it is necessary to inquire into whether a justification for the incorporation strategy can be constructed that takes merchant reality as its starting point. ${ }^{247}$ This inquiry is particularly timely, not only because the revised Code-which extends the incorporation principle-will soon be submitted to the States for their approval, but also because proposals to create commercial law in transition economies often take as their starting point the desirability of codifying existing commercial practices.

\footnotetext{
${ }^{247}$ Even if, in merchant industries that adopted trade rules, customs arose as ranges around these focal point rules, this would still not justify the incorporation strategy. The industries that have adopted such rules are, for the most part, precisely those that have also chosen to opt out of the public legal system, making it much less common for their disputes to wind up being governed by the Code in the first place.
} 